UNIVERSIDADE DE SÃO PAULO

FACULDADE DE MEDICINA DE RIBEIRÃO PRETO

DEPARTAMENTO DE GENÉTICA

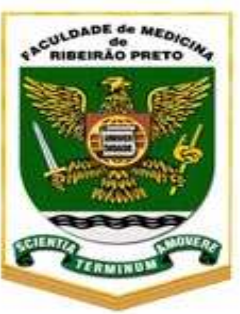

\title{
ANÁLISE DO PERFIL DE EXPRESSÃO DE GENES RELACIONADOS À RESISTÊNCIA A QUIMIOTERÁPICOS NA LEUCEMIA LINFÓIDE AGUDA DA CRIANÇA E DO
} ADOLESCENTE.

Vanessa da Sütra Sitveira

Tese apresentada à Faculdade de Medicina de Ribeirão Preto da Universidade de São Paulo para a obtenção do título de Doutor em Ciências, área de concentração Genética.

Orientador: Prof. Dr. Luiz Gonzaga Tone 


\section{FICHA CATALOGRÁFICA}

Silveira, Vanessa da Silva

Análise do perfil de expressão de genes relacionados à resistência a quimioterápicos, na leucemia

linfóide aguda da criança e do adolescente. Ribeirão Preto, 2009. 131 pp.:il., $28 \mathrm{~cm}$

Tese apresentada à Faculdade de Medicina de Ribeirão Preto da Universidade de São Paulo para a obtenção do título de Doutor em Ciências, área de concentração Genética.

Orientador: Tone, Luiz Gonzaga

1. Expressão Gênica. 2. Leucemia Linfóide Aguda. 3. Resistência/Sensibilidade. 4. Quimioterapia 


\section{Apoio e Suporte Financeiro}

Este trabalho foi realizado com o apoio financeiro das seguintes instituições:

$\checkmark$ Fundação de Amparo à Pesquisa do Estado de São Paulo - FAPESP (Processo $n^{\circ}$ 06/02579-2).

$\checkmark$ Fundação de Apoio ao Ensino, Pesquisa e Assistência do Hospital das Clínicas de Ribeirão Preto/USP - FAEPA.

$\checkmark$ Faculdade de Medicina de Ribeirão Preto - FMRP/USP

$\checkmark$ Hospital das Clínicas da Faculdade de Medicina de Ribeirão Preto USP. 


\section{FOLHA DE APROVAÇÃO}

Vanessa da Silva Silveira

Análise do perfil de expressão de genes relacionados à resistência a quimioterápicos, na leucemia

linfóide aguda da criança e do adolescente.

Tese apresentada à Faculdade de Medicina de Ribeirão Preto da Universidade de São Paulo para a obtenção do título de Doutor em Ciências.

Área de concentração: Genética.

Aprovado em:

Banca examinadora

Prof. Dr.

Instituição:

Assinatura:

Prof. Dr.

Instituição: Assinatura:

Prof. Dr.

Instituição:

Assinatura:

Prof. Dr.

Instituição: Assinatura:

Prof. Dr.

Instituição: Assinatura: 
Aos mens pais José Teruel e Maria A métia

Pelo exemplo de dignidade, perseveranca e luta! Obrigada por estarem sempre ao meu lado em cada nova conquista!

Amovocês! 


\section{AGRADECIMENTOS}

Ao mew orientador, Prof. Dr. Luiz Gonzaga Tone ... um grande exemplo de profissional e de ser humano que me recebeu com todo carinho e respeito sem ao menos me conhecer, depositando em mim toda a sua confiança. Sow imensamente grata pela atenção, disponibilidade e imenso carinho dedicados durante todo $\sigma$ processo da minha formação. Além disso por me ensinar a lidar com cada momento de dificuldade, me ensinando a amadurecer e me tornar não somente uma profissional melhor mas acima de tudo uma pessoa melhor. Muito obrigada!

Ao Prof. Dr. Carlos Alberto Scrideli, que participow ativamente deste trabalho, desde a sua elaboração, com sugestões e assistência na parte clinica e laboratorial que foram fundamentais para o sew desenvolvimento e conclusão.

À Profa. Dra. Rosane Gomes de Paula Queiroz, pela disponibitidade e dedicação prestadas desde o inicio do desenvolvimento desse trabalho até a sua conchusão e acima de tudo pela grande amizade que construimos durante todos esses anos!

Ao Prof. Dr. Ademilson Espencer Egea Soares, Coordenador da Pós-Graduação do Departamento de Genética, por toda atenção e apoio incondicionais em todas os momentos do curso de pós graduação!

À Profa Dra. Maria Sol Annichinni Brassesco, por todas as sugestões, criticas e ensinamento durante $\sigma$ desenvolvimento desse projeto. Sua incrivel competência, dedicação, companheirismo e acima de tudo a grande amizade foram fundamentais para a conchusão deste trabalho!

Às funcionárias Maria Aparecida O. S. Elias e Susie Adriana R. P. Nalon, da secretaría do Departamento de Genética da FMRP-USP, pela atenção e ajuda prestada em todos os momentos. 
Ao Dr. Elvis Terci Valera, pelo enriquecimento do trabalho com ótimas sugestões e pelo excelente convívio durante todos esses anos de trabalho em equipe!

À todos os meus grandes amigos do laboratório: Andressa, Angélica, Cris, Daniel, Jaque, Juli, Malu, Kleiton e Mauricio. Serei eternamente grata por ter encontrado amigos como vocês. Obrigada por cada um dos momentos incriveis que passamos juntos, discutindo experimentos, artigos e principalmente as famosas pausas para o café! Construimos uma família que ew adoro!

Ao pessoal do Laboratório de Citogenética: Aidê, Lucimar, Matu e Sônia pela convivência tão agradável e também às funcionãrias Silvia e especialmente à Walquiria peto imenso carinho e dedicação durante todos esses anos!

À secretária do laboratório de Pediatria: Evelise, por todo auxílio prestado durante o desenvolvimento desse trabalho.

Aos grandes amigos que me apoiaram durante todo esse tempo: Cris, Érica, Fábio Motta, Juliana, Juliana Meola, Karina, Renata, Patricia e especialmente à Virginia pelo companheirismo e pela grande amizade durante esses anos!

Ao mew irmão do coração, Sérgio, pela amizade, dedicação, incentivo e apoio incondicionais durante todos os momentos da minha vida!

Aos pacientes que gentilmente forneceram o material indispensável para a realização deste estudo.

Aos Membros da Banca Examinadora, pela disponibitidade de anátise desse trabatho, enriquecendo-o com suas críticas e sugestöes.

A todos que de alguma maneira contribuiram para a realização desse trabatho 
"O aspecto mais triste da vida de hoje é que a ciência ganha em conhecimento mais rapidamente que a sociedade em sabedoria". 


\section{RESUMO}

\section{SILVEIRA, V. S. Análise do perfil de expressão de genes relacionados à resistência}

a quimioterápicos na leucemia linfóide aguda da criança e do adolescente. 2009, 131f. Tese de Doutorado - Faculdade de Medicina de Ribeirão Preto, Universidade de São Paulo, Ribeirão Preto, SP, Brasil.

Com a utilização dos atuais protocolos de tratamento, $70-80 \%$ dos casos de leucemia linfóide aguda (LLA) na infância têm obtido sobrevida livre de eventos em cinco anos. Entretanto, os $20 \%$ restantes, que se mostram resistentes ao tratamento, apresentam recidivas e as causas desse insucesso no tratamento ainda permanecem desconhecidas. Dessa forma, com o intuito de melhor compreender os mecanismos moleculares que participam desse processo, o presente trabalho teve por objetivo avaliar o perfil de expressão de um painel de genes que foram previamente associados à resistência e/ou sensibilidade aos quimioterápicos: prednisona ( $F 8 A, C D K 2 A P 1, B L V R B, C D 69)$, vincristina (RPLP2, CD44, TCFL5, KCNN1, TRIM24), daunorrubicina (MAP3K12, SHOC2, PDCH9, EGR1, KCNN4) e asparaginase (GPR56, MAN1A1, CLEC11A, IGFBP7, GATA3). Para a realização do estudo, foram utilizadas inicialmente amostras de medula óssea de pacientes portadores de LLA pertencentes a quatro grandes centros de oncologia pediátrica do Estado de São Paulo e que foram submetidos ao protocolo de tratamento do GBTLI-99. A análise da expressão gênica foi realizada pela técnica de PCR quantitativa em tempo real, utilizando-se o reagente $S Y B R$ Green, o gene GUS $\beta$ como controle endógeno e amostras de medula óssea normais como referência. A análise dos dados de expressão gênica em relação aos diversos parâmetros clínicos e laboratoriais avaliados na LLA, demonstrou associações importantes entre os diversos genes estudados e variáveis clínicas importantes como contagem de glóbulos brancos ao diagnóstico, presença do antígeno CD10 (CALLA), translocação TEL/AML1, presença de doença residual mínima entre outras. Dentre os genes avaliados destacaram -se como possíveis marcadores de bom prognóstico os genes SHOC2 e GPR56. Posteriormente, reavaliou-se o perfil de expressão desses genes em pacientes submetidos ao protocolo de tratamento europeu do grupo BFM com o intuito de verificar o padrão de expressão em pacientes com um background genético distinto e submetidos a um protocolo terapêutico distinto. Os resultados confirmaram os dados encontrados anteriormente e demonstraram a hiperexpressão do gene SHOC2 (que foi previamente associado à sensibilidade à daunorrubicina) associada ao grupo de pacientes bons respondedores, sugerindo a correlação desse gene com critérios favoráveis de prognóstico. Para verificar o nível de interação desse gene avaliou-se ainda a expressão protéica do mesmo, que confirmou os padrões de expressão gênica obtidos por RQ-PCR. A função do gene $S H O C 2$, que embora não esteja completamente elucidada, já foi anteriormente descrita pela literatura, que demonstra a participação do gene no processo de ativação da proteína Erk pela via Ras. Finalmente para melhor compreender os possíveis mecanismos que envolvem o gene SHOC2 no processo de melhor resposta à quimioterapia, utilizou-se a técnica de RNAi para silenciálo na linhagem celular leucêmica Jurkat. Os resultados demosntraram a associação da expressão do gene $S H O C 2$ com proliferação celular e também com a indução de apoptose. Esses dados sugerem que a hiperexpressão desse gene pode ser importante para o processo de sensibilidade das células leucêmicas ao tratamento. Como conclusão, este trabalho demonstrou a associação de diversos genes com importantes parâmetros clínicos da LLA e destaca principalmente o papel do gene SHOC2 como possível alvo terapêutico para o tratamento da leucemia linfóide aguda.

Palavras chave: LLA, perfil de expressão gênica, resistência ao tratamento, SHOC2. 


\begin{abstract}
SILVEIRA, V. S. Expression profile of genes related to chemotherapy resistance in childhood acute lymphoblastic leukemia. 2009. 131f. Doctoral Thesis - School of Medicine of Ribeirao Preto, University of São Paulo, Ribeirao Preto, SP, Brazil.
\end{abstract}

Major improvements have been made in the ALL treatment, which achieved successful rates of approximately $80 \%$ of long-terms survival. Despite the significant percentage of success, the remaining $20 \%$ still presents treatment failure and the molecular mechanisms involved in the resistance process remains unclear. The present study was undertaken to analyze and validate the gene expression pattern of the previously described genes related to prednisolone (F8A, CDK2AP1, BLVRB, CD69), vincristine (RPLP2, CD44, TCFL5, KCNN1, TRIM24), daunorubicin (MAP3K12, SHOC2, PDCH9, EGR1, KCNN4) and Lasparaginase (GPR56, MAN1A1, CLEC11A, IGFBP7, GATA3) in order to better inderstand these mechanisms. Bone marrow samples of ALL patients, obtained at diagnosis, in four oncology centers and treated according to the Brazilian protocol (GBTLI-99). The relative mRNA expression levels were quantified using real-time PCR analysis. Amplification of the specific sequences was performed with SYBR® Green reagent; GUSB was used as the reference gene and normal bone marrow samples used as calibrator. The expression profile analisis showed important associations among the studied genes and clinical features as WBC count at diagnosis, CALLA, TEL/AML1 translocation and minimal residual disease. Among the analyzed genes, possible therapy targets were found at SHOC2 and GPR56. Further we addressed the expression profile of these genes in ALL patients, treated according to the BFM protocol, which chacarterize a group of distinct genetic's background. The results confirmed the data previously obtained. The overexpression of the gene SHOC2, that was primaraly associated to sensibility to dauborubicin, was related to patients who presented good prednisone response, suggesting the correlation of SHOC2 with good prognostic factors. In order to acess the interaction level of this gene, the protein expression was analyzed and confirmed the mRNA expression data. Despite its lack of information, the data on SHOC2 shows its role as na important element in the Erk activation by Ras induced pathway. Finally, to better understand the possible mechanisms which involve SHOC2 gene to the chemotherapy response process, Jurkat cells was transfect with siRNA to silence the gene SHOC2. Further, functional assays were done to characterize the mechanisms involved. The results showed the association of SHOC2 gene expression with processes of cell proliferation and apoptosis induction, thus suggesting that the overexpression of SHOC2 could play an important role in leukemic cell's sensibility to chemotherapy agents, and consequently in patients' treatment outcome. In conclusion, this work demonstrated the association of the expression profile of many genes with important clinical and laboratorial features. Furthermore, this data present the gene SHOC2 as a possible therapy target to acute lymphoblastic leukemia 's treatment.

Key words: ALL, gene expression profile, chemotherapy resistance, SHOC2 


\section{LISTA DE ILUSTRAÇÕES}

FIGURA 1: Curva de amplificação e dissociação da amostra LE4/0053 para o gene SHOC2... 47

FIGURA 2: Frequência das sequências 9-mers mais prevalentes incluídas na "Universal Probe Library". Fonte: https:/ / www.roche-applied-science.com/sis/rtpcr/upl/index .

FIGURA 3: Perfil de expressão gênica dos genes TRIM24, TCFL5, KCNN1, PCDH9 e CD69 em relação à presença de doença residual mínima no $28^{\circ}$ dia após a indução

FIGURA 4: Sobrevida livre de eventos para os grupos de pacientes com expressão do gene F8A $(\mathrm{p}=0,781)$ e CDK2AP1 $(0,062)$

FIGURA 5: Sobrevida livre de eventos para os grupos de pacientes com expressão do gene $C D 69(\mathrm{p}=0,285)$ e $B L V R B(\mathrm{p}=0,854)$ 66

FIGURA 6: Sobrevida livre de eventos para os grupos de pacientes com expressão do gene KCNN1 ( $\mathrm{p}=0,662)$ e RPLP2 $(\mathrm{p}=0,453)$ 66

FIGURA 7: Sobrevida livre de eventos para os grupos de pacientes com expressão do gene CD44 ( $\mathrm{p}=0,692)$ e GPR56 ( $\mathrm{p}=0,052)$.

FIGURA 8: Sobrevida livre de eventos para os grupos de pacientes com expressão do gene MAN1A1 ( $\mathrm{p}=0943)$ e TCFL52 $(\mathrm{p}=0,094)$.

FIGURA 9: Sobrevida livre de eventos para os grupos de pacientes com expressão do gene SHOC2 $(\mathrm{p}=0,023)$ e MAP3K12 $(\mathrm{p}=0,547)$

FIGURA 10: Sobrevida livre de eventos para os grupos de pacientes com expressão do gene GATA3 $(\mathrm{p}=0,617)$ e PCDH9 $(\mathrm{p}=0,857)$

FIGURA 11: Sobrevida livre de eventos para os grupos de pacientes com expressão do gene KCNN4 $(\mathrm{p}=0,626)$ e IGFBP7 $(\mathrm{p}=0,182)$.

FIGURA 12: - Sobrevida livre de eventos para os grupos de pacientes com expressão do gene EGR1 $(\mathrm{p}=0,500)$ e CLEC11A $(\mathrm{p}=0,991)$.

FIGURA 13: Sobrevida livre de eventos para os grupos de pacientes com expressão do gene TRIM24 $(\mathrm{p}=0,407)$

FIGURA 14: Perfil de expressão do gene $S H O C 2$ entre os grupos de pacientes de alto e baixo risco $\equiv$.

FIGURA 15: Perfil de expressão do gene GPR56 entre os grupos de pacientes de alto e baixo $\equiv \mathrm{b}$

FIGURA 16: Perfil de expressão do gene $S H O C 2$ entre os pacientes de riscos básico e alto e pacientes com lenta resposta à prednisona. Risco básico vs maus respondedores apresentaram $\mathrm{p}=0,009$ e alto $\equiv \mathrm{b}$ vs maus respondedores $\mathrm{p}=0,06$. 
FIGURA 17: Perfil de expressão do gene GPR56 entre os pacientes de riscos básico, alto e pacientes com lenta resposta à prednisona

FIGURA 18: Perfil de expressão dos genes $S H O C 2$ e GPR56 em relação à contagem inicial de glóbulos brancos (WBC); $\mathrm{p}=0,06$ e $\mathrm{p}=0,11$ respectivamente).

FIGURA 19: Perfil de expressão do gene $S H O C 2$. A) Perfil de expressão gênica através de RT-PCR quantitativa e B) Confirmação da expressão protéica através da análise realizada por 三tern blotting

FIGURA 20: Silenciamento gênico do gene SHOC2. Silenciamento gênico $\equiv$ dução de 83\% na expressão gênica do gene SHOC2 48 horas após a transfecção com o sisतiOC2. Os dados representam a média de três experimentos independentes.

FIGURA 21: Western blotting para análise da expressão protéica da proteína SHOC2. A supressão protéica foi verificada 96 horas após a transfecção. A expressão de GAPDH foi utilizada como controle.

FIGURA 22: Proliferação celular da linhagem Jurkat Padrão de proliferação obtido após a transfecção das linhagens com o siSHOC2 e com o siRNA controle negativo em relação à linhagem celular normal (não transfectada). O gráfico representa os dados obtidos através da média de três experimentos independentes (desvio padrão $<0,05$ )

FIGURA 23: Ensaio $\equiv$ iabilidade celular. Padrão de necrose celular $\equiv$ liados 96 horas após a transfecção demonstrando a redução da porcentagem de necrose celular entre a linhagem transfectada com siSHOC2 em relação ao controle negativo $(p=0,02)$

FIGURA 24: Ensaio $\equiv$ ndução de apoptose . Padrão de indução de apoptose $\equiv$ liado 96 horas após a transfectção demonstrando a redução da porcentagem de apoptose entre a linhagem transfectada com siSHOC2 em relação ao controle negativo $(p=0,50)$ e à linhagem normal não transfectada $(p=0,03)$.

FIGURA 25: Via Ras/Raf/Mek/Erk. Via regulada por RAS assim como diversas outras quinases que fosforilam os residuos de RAF. Os eventos de fosforilação podem induzir a atividade de Raf ( círculos brancos) como também para inibir ( círculos pretos). Os fatores de transcrição downstream que são regulados por essa via se encontram destacados em triângulos (Adaptada segundo McCubrey et.al., 2007)..... 


\section{LISTA DE TABELAS}

TABELA 1: Genes associados à resistência/sensibilidade aos quimioterápicos identificados por Holleman e colaboradores (2004) ……..................................................................................... 29

TABELA 2: Características Clínicas dos pacientes do grupo AIEOP .............................................. 40

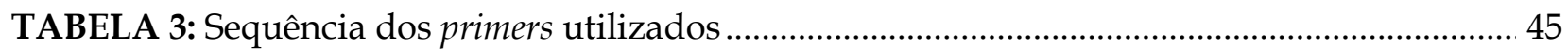

TABELA 4: Sequência de primers e suas respectivas sondas.............................................................. 49

TABELA 5: Genes de resistência/sensibilidade a quimioterápicos .................................................. 58

TABELA 6: - Valores de média e desvio padrão, mediana e percentís dos genes analisados........ 58

TABELA 7: Expressão relativa dos genes analisados em relação à contagem de glóbulos

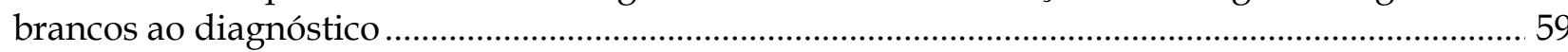

TABELA 8: Expressão relativa dos genes analisados em relação ao marcador CD10 (CALLA) ... 60

TABELA 9: Expressão relativa dos genes analisados em relação à Medula óssea no $28^{\circ}$ dia ......... 60

TABELA 10:- Expressão relativa dos genes analisados em relação à presença de translocações .. 62

TABELA 11: Expressão relativa dos genes analisados em relação ao imunofenótipo

TABELA 12: Correlação entre as variáveis clínicas e a expressão dos demais genes analisados (valores de $\mathrm{p}$ )

TABELA 13: Coeficiente de relação de Spearman observado entre os genes associados à prednisona

TABELA 14: Coeficiente de relação de Spearman observado entre os genes associados à vincristina.

TABELA 15: Coeficiente de relação de Spearman observado entre os genes associados à daunorrubicina

TABELA 16: Coeficiente de relação de Spearman observado entre os genes associados à asparaginase 
LISTA DE ABREVIATURAS

AIEOP - Associazione Italiana Ematologia Oncologia Pediatrica

AR - Alto risco

BFM- Berlim-Frankfurt-Munique

BSA - Albumina do soro bovino

CALLA - Common Acute lymphoblastic leukemia antigen

CD- Cluster of differentiation

CDK - Cyclin dependent kinase

cDNA - ácido desoxirribonucléico complementar

DAF - Diacetato de fluoresceína

DAPI - 4,6-di-amido-2-2-phenylindole dihydrochloride

DMSO - Dimetilsulfóxido

DNA - Desoxiribonucleic acid

DRM - Doença residual mínima

EDTA - ácido etilenodiamino tetra-acético

FITC - Fluoresceiniso- thiocyanate;

GBTLI - Grupo brasileiro de Tratamento da Leucemia infantil

HLA- Human leukocyte antigen

HTLV1- Human T lymphotropic virus type 1

IOP - Instituto de Oncologia Pediatrica

LLA- Leucemia Linfóide Aguda

MADIT - Metotrexato.AraC. Dexametasona. Intratecal 
MDR - Multiple drug resistance

MEM- Meio mínimo essencial

MRP - Proteína de resistência múltipla a drogas

MTX - Metotrexato

Pgp - Glicoproteína P

RB - Risco Básico

RCC - Remissão Clínica Completa

RNA - Ribonucleic Acid

RNAi - RNA de interferência

RPMI - Roswell Park Memorial Institute

RT-PCR - Reverse Transcriptase Polimerase chain reaction

SHOC2 - Soc-2 suppressor of clear homolog

siRNA - small interfering RNA

SLE - Sobrevida livre de eventos

SNC - Sistema nervoso central

TBST- Tris-Buffered-saline - Tween20

TCR - T cell receptor

UPL - Universal Probe Library 


\section{SUMÁRIO}

1. INTRODUÇÃO

1.1 LEUCEMIA LINFÓIDE AGUDA NA INFÂNCIA................................................18

1.1.1 Classificação ………………………………………...................................19

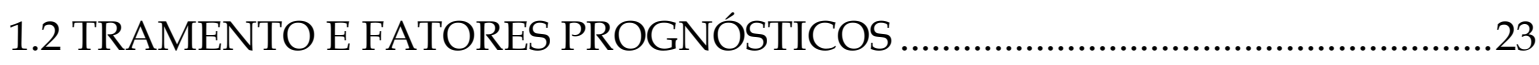

1.3 MECANISMOS DE RESISTÊNCIA AO TRATAMENTO …………………….......27

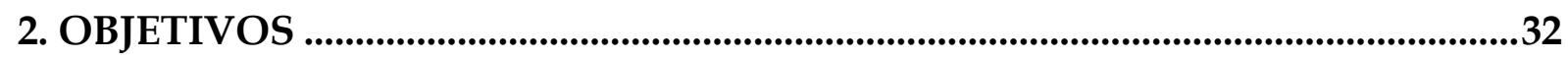

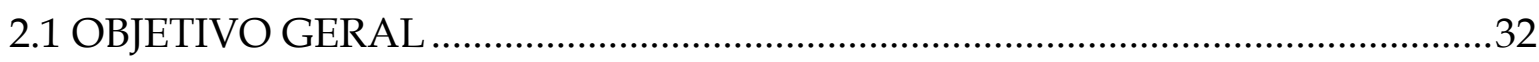

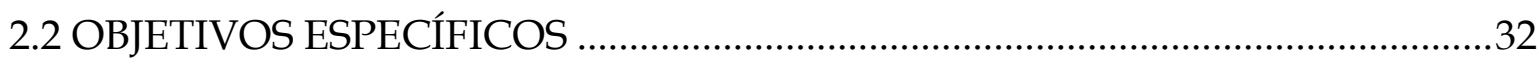

3. CASUÍSTICA E MÉTODOS...........................................................................................34

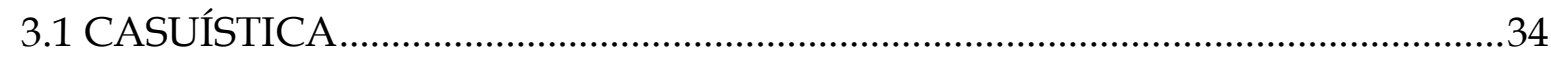

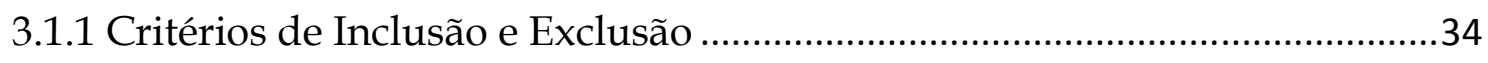

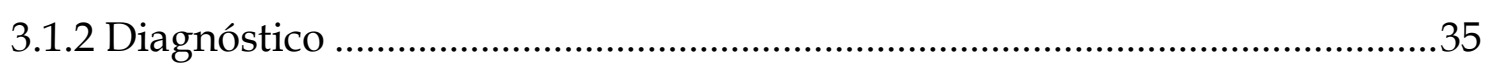

3.1.3 Caracterização dos Pacientes.............................................................................

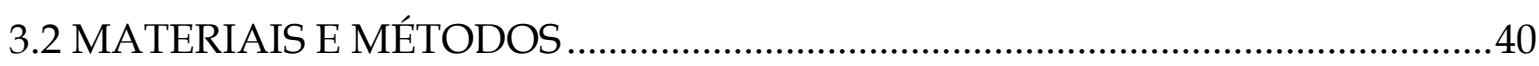

3.2.1 Coleta de Amostras.......................................................................................40

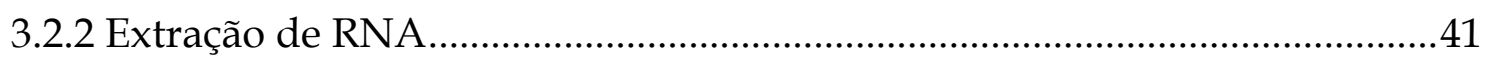

3.2.3 Síntese de DNA complementar (cDNA)..........................................................42

3.2.4 Controle Endógeno ………………………………….................................4

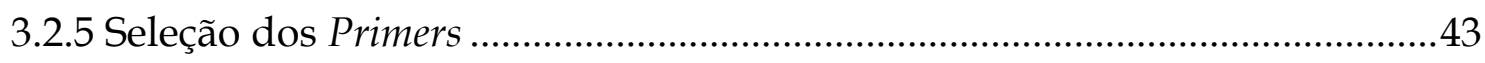

3.2.6 PCR Quantitativo em Tempo Real (RQ-PCR)..................................................4

3.2.6.1 Construção de curvas-padrão ............................................................45

3.2.6.2 Condições padronizadas para as reações de RQ-PCR …………….....46

3.2.6.3 Quantificação da Expressão Gênica ....................................................49

3.2.7 Análise da expressão proteica - Western Blotting...............................................50

3.2.7.1 Extração de proteínas ……………………………………………......50

3.2.7.2 Western Blotting ................................................................................... 51

3.2.8 Silenciamento por RNA de interferência (RNAi) ..........................................52

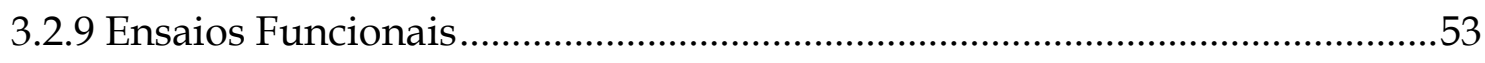

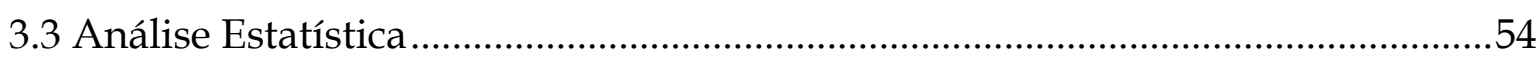


4.1 ANÁLISE DE EXPRESSÃO GÊNICA - Genes envolvidos com resistência/ sensibilidade a quimioterápicos em pacientes portadores de LLA submetidos ao protocolo do GBTLI-99

4.2 ANÁLISE DE SOBREVIDA LIVRE DE EVENTOS - Pacientes portadores de LLA submetidos ao protocolo de tratamento do GBTLI

4.3 ANÁLISE DE CORRELAÇÃO ENTRE OS VALORES DE EXPRESSÃO .70

4.4 ANÁlISE DE EXPRESSÃO GÊNICA DOS GENES SHOC2 E GPR56 Pacientes portadores de LLA submetidos ao protocolo de tratamento BFM-2000..73 4.5 ANÁLISE DA EXPRESSÃO PROTÉICA DO GENE SHOC2. .78 4.6 SILENCIAMENTO DO GENE SHOC2 POR RNAI..................................................

4.7 ENSAIO DE PROLIFERAÇÃO E VIABILIDADE CELULAR .................................83

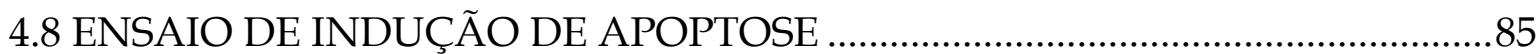

5. DISCUSSÃO 89

5.1 ANÁLISE DO PERFIL DE EXPRESSÃO GÊNICA 89

5.1.1 Padrão de expressão dos genes associados à prednisona. 89

5.1.2 Padrão de expressão dos genes associados à vincristina .................................94

5.1.3 Padrão de expressão dos genes associados à L- asparaginase ......................97

5.1.4 Padrão de expressão dos genes associados à daunorrubicina ......................101

5.2 PAPEL DO GENE SHOC2 - Processo de resposta ao tratamento em LLA......104

5.2.1.Análise do perfil de expressão gênica e protéica ...........................................104

5.3 CONSIDERAÇÕES FINAIS ................................................................................110

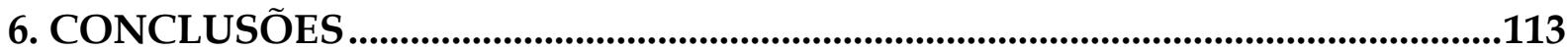

7. REFERÊNCIAS BIBLIOGRÁFICAS .................................................................116

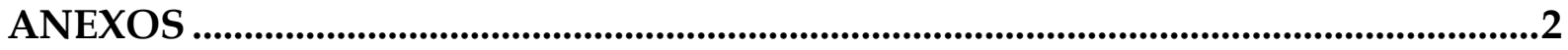

ANEXO A - Carta de Aprovação do Comitê de Ética em Pesquisa do HC-FMRP-USP ........... 2

ANEXO B - Carta de Manifestação do CONEP ..................................................................... 
Introducão 


\section{INTRODUÇÃO}

\subsection{LEUCEMIA LINFÓIDE AGUDA NA INFÂNCIA}

Dentre todos os tipos de neoplasias malignas que acometem a faixa etária pediátrica a leucemia representa o tipo mais frequente e corresponde a aproximadamente $35 \%$ de todos os tipos de câncer da infância, sendo a leucemia linfóide aguda (LLA) a mais frequentemente encontrada (Gunz, 1990; Pui, 2009).

A LLA é uma desordem maligna de células progenitoras linfóides caracterizada pelo acúmulo clonal de linfócitos imaturos na medula óssea. O clone, que sofre a transformação, pode ser originado de células pluripotentes ou de células progenitoras mais maduras e, as aberrações que ocorrem nos mecanismos de proliferação e diferenciação dessas células comprometem a hematopoiese (Lightfoot, 2005; Kebriaei et al., 2003).

A sintomatologia da doença é bastante variável, dependendo das alterações das séries vermelha, branca e megacariocítica. São frequentes palidez, apatia, taquicardia, febre e infecções recorrentes (ocasionadas pela falência da série branca e conseqüente diminuição dos leucócitos normais). Além desses sintomas, o paciente pode apresentar sangramento, petéquias disseminadas (causadas pela falência da série megacariocítica) e sintomas associados ao acometimento de órgãos específicos como testículos e periósteo. O envolvimento do sistema nervoso central também é frequente (Kebriaei et al, 2003; Pui; Thiel, 2009). 
A LLA acomete mais frequentemente o sexo masculino e apresenta picos de incidência entre o segundo e o quinto ano de vida, regredindo progressivamente nas faixas etárias subsequentes. Há ainda uma variação étnica indicando maior incidência em crianças brancas em relação às crianças negras (Smith et al., 1999, Adelman, et al., 2007).

A causa mais provável da LLA pode ser explicada pela interação entre fatores como a susceptibilidade herdada, alterações do desenvolvimento hematopoiético e a exposição ambiental (pré ou pós natal). Dentre os fatores ambientais possivelmente associados, estão os agentes físicos (radiação ionizante), químicos (derivados de benzeno) e também biológicos como, por exemplo, os vírus Epstein Barr e HTLV-I (Margolin et al., 2002).

\subsubsection{Classificação}

As leucemias são classificadas de acordo com a fase do desenvolvimento hematopoiético normal em que ocorreu a transformação da célula maligna, utilizando para tal, métodos imunológicos, enzimáticos e moleculares (Pui, 2006).

As células blásticas são facilmente reconhecíveis e, na maioria das vezes, a distinção entre blastos de origem linfóide ou mielóide pode ser feita através da microscopia óptica. A classificação, proposta pelo French-American-British (FAB) Cooperative Working Group na década de 70, divide as LLAs em três subtipos (L1, L2 e L3) segundo critérios morfológicos específicos dos blastos. A distinção entre os subtipos L1 e L2 ainda não se mostrou útil para definição prognóstica e/ou 
terapêutica. Por outro lado o subtipo L3 é atualmente conhecido como Leucemia de células-B maduras e é claramente reconhecido como uma entidade à parte das demais. (Gustafson; Lie, 1998; Margolin; Poplack, 1997).

A classificação imunofenotípica é essencial para confirmar o diagnóstico da LLA e sub classificar a linhagem como precursora de células B ou células T. A maioria das células blásticas mantém características dos progenitores hematopoéticos normais, permitindo assim uma comparação imunológica baseada na reatividade com um painel de anticorpos linhagem-específico. Os antígenos associados com as diferentes fases de maturação podem ser detectados por anticorpos monoclonais. Tais anticorpos são agrupados conforme a molécula que reconhecem sob um número de cluster de diferenciação (CD) existindo diversos marcadores para a imunofenotipagem nas leucemias (Pileri et al., 1999).

A vasta maioria dos casos de LLA ( 75\%) é de linhagem B e são divididas de acordo com os estágios de diferenciação normal dos progenitores B na medula óssea, classificando-se em: pró-B, precursor B comum, pré-B e B-maduro. Na LLA do tipo pró-B as células expressam: HLA-DR, Terminal Desoxinucleotidil Transferase (TdT), CD34, CD19 e CD22. A LLA do tipo comum (CALLA) expressa CD10, CD22, CD19 e/ou CD20. A leucemia pré-B expressa cadeia $\mu$ citoplasmática, em adição a CD19, CD20 e CD10. Finalmente, a LLA do tipo B maduro, caracteriza-se pela expressão de cadeias leves de imunoglobulina na superfície de membrana (smIg) (Kotilo, 1995; Vassef, et al., 1998).

As LLAs de linhagem $\mathrm{T}$ representam apenas $15 \%$ do total dos casos e são divididas em três subgrupos, de acordo com os antígenos de diferenciação 
correspondentes ao estágio de maturação dos timócitos: LLA pré-T, T-intermediário ou comum e maduro. Na LLA pré-T, as células expressam CD3 no citoplasma, mas não na superfície celular, expressando caracteristicamente CD7, CD2, CD5 e TdT. Na LLA do tipo T intermediário, as células passam a expressar fortemente CD3c, CD2, CD1a e podem co-expressar CD4 e CD8. A LLA do terceiro grupo corresponde aos timócitos maduros, expressa CD2, CD5, CD7, CD3, sendo duplamente positiva para CD4 e CD8. (Pui et al., 1993; Stasi et al., 1995; Margolin; Poplack, 1997).

Estudos genéticos identificaram a origem pré natal de algumas leucemias através da presença de leucemia concordante entre gêmeos idênticos e também da presença de genes de fusão leucêmico-específicos tais como os genes MLL-AF4 e ETV6/RUNX1 em amostras de sangue neonatal (Ford et al., 1997; Wielms et al., 1999). Receptores de células T (TCR), que apresentam clonogenicidade de cadeias pesadas também podem ser utilizados como marcadores de células leucêmicas e pré leucêmicas ao nascimento (Taub et al., 2002; Levine, 2009). O alto índice de concordância (25-100\%) dos genes de fusão MLL-AF4 entre gêmeos idênticos e o curto período de latência sugerem que esses eventos poderiam ser suficientes para desencadear a leucemogênese ou pelo menos induzir alterações secundárias que levariam ao processo. Em outros tipos de leucemias como aquelas que apresentam o gene de fusão ETV6/RUNX1, ou leucemias do tipo T, o índice de concordância é menor e o período de latência pós natal é maior e bastante variável, sugerindo que a presença de um evento molecular secundário é necessária para a completa transformação leucêmica (Greaves, 1999; Zuna et al., 2009). 
Várias anormalidades cromossômicas constitucionais estão associadas às leucemias agudas. Crianças com Síndrome de Down apresentam risco de dez a vinte vezes maior de desenvolver a doença do que crianças normais (Xavier et al., 2009). Outras síndromes genéticas associadas à ocorrência de LLA incluem a síndrome de Bloom, anemia de Fanconi, ataxia telangectasia e síndrome de Klinefelter (Margolin et al., 2002).

As leucemias podem, ainda, ser classificadas segundo a presença de alterações cromossômicas. Aproximadamente 75\% das crianças com LLA apresentam anormalidades cromossômicas que, além de caracterizar outra esfera de classificação, representam um importante fator prognóstico (Pui, 1998; Mrózek et al., 2009). Dentre todas as alterações cromossômicas, as numéricas destacam-se como as mais frequentemente encontradas. Cariótipos hiperdiplóides com contagem superior a 50 cromossomos são encontrados em cerca de $20 \%$ dos casos e apresentam prognóstico bastante favorável, o qual pode ser atribuído ao impacto das trissomias dos cromossomos 4, 10 e 17, normalmente associadas à sobrevida livre de eventos (SLE) em 5 anos superior a 90\% (Carrol, et al., 2003). Por outro lado, os casos hipodiplóides, que representam cerca de $8 \%$ dos casos pediátricos, são considerados de mau prognóstico (Margolin; Polplack, 1997; Nachman et al., 2007).

Com relação às anormalidades estruturais, destacam-se as translocações cromossômicas recorrentes, que ocorrem em um terço dos pacientes e já foram descritas como um dos primeiros eventos no processo de leucemogênese, ocorrendo ainda durante o desenvolvimento fetal (Wiemels et al., 1999; Greaves, 2002). Dentre elas, quatro translocações principais foram identificadas e definem, 
cada uma delas, um subtipo biológico diferente de pacientes. A t(1;19)(q23;q13), comumente observada nas LLAs pré-B, caracteriza-se pela fusão dos genes E2A e PBX. Recentemente, a utilização de protocolos terapêuticos mais agressivos contribuiu para diminuir o impacto negativo classicamente atribuído a esta translocação (Carrol et al., 2003).

A alteração mais comum, encontrada em $25 \%$ dos casos, é a $\mathrm{t}(12 ; 21)(\mathrm{p} 13 ; \mathrm{q} 22)$, causada pela fusão dos genes ETV6/RUNX1 e considerada como fator prognóstico favorável. A translocação t(9,22) (cromossomo Philadelphia), resultante da fusão dos genes $B C R-A B L 1$ é encontrada em aproximadamente $5 \%$ das crianças com LLA e está associada a um prognóstico extremamente desfavorável, assim como a translocação $t(4 ; 11)(q 21,23)$, que pode ser observada em cerca de $3 \%$ das LLAs em crianças, principalmente nos lactentes e envolve a justaposição dos genes MLL e AF4 (Raynaud et al., 1996; Pui; Evans, 2006). Outras translocações que podem estar envolvidas são: $\mathfrak{t}(8 ; 14), \mathfrak{t}(2 ; 8)$ e $\mathrm{t}(8 ; 22)$ (envolvendo o proto- oncogene MYCC) e também a $\mathrm{t}(11 ; 14)$ com ponto de quebra no cromossomo 14 no locus a/ $\delta$ do gene TCR, (14q32) representando a translocação mais frequente entre as LLAs de linhagem T da infância ( Privitera et al., 1992; Pui, 1995; Margolin; Poplack, 1997; Pui et al., 2004; Lightfoot, 2005).

\subsection{TRAMENTO E FATORES PROGNÓSTICOS}

Descrita inicialmente por Pinkel e colaboradores (1971), a base do tratamento da LLA preconiza a combinação de drogas com diferentes mecanismos 
de ação, e a administração da quimioterapia intratecal e da radioterapia craniana como medida de profilaxia para o sistema nervoso central.

O esquema de quimioterápicos é modificado conforme o grupo de risco e a duração do tratamento pode compreender de 2 a 3 anos. No tratamento direcionado ao sistema nervoso central, a radioterapia craniana, antes extensivamente utilizada, atualmente tem sido substituída por regimes de quimioterapia sistêmica e intratecal mais intensivos, com o objetivo de diminuir as complicações neurológicas e a incidência de neoplasias secundárias (Relling et al., 1999; Carroll et al., 2003).

Com a utilização dos atuais protocolos de tratamento $70-80 \%$ dos casos de leucemia linfóide aguda da criança têm obtido sobrevida livre de eventos em 5 anos (Pui; Evans, 2006). Os altos índices de sobrevida livre de eventos alcançados atualmente no tratamento de crianças com LLA, são resultados de uma série de ensaios terapêuticos conduzidos por diversos grupos cooperativos multicêntricos. De maneira geral, o tratamento de crianças com LLA consta de três fases terapêuticas principais: indução, intensificação, consolidação, profilaxia do sistema nervoso central (SNC) e manutenção e estão descritos detalhadamente no esquema abaixo GBTLI-99).

ESQUEMA PARA GRUPO DE BAIXO RISCO:

$>$ Indução: Prednisona, Vincristina, Asparaginase, Daunorrubicina, MTX/Ara-C/Dexa Intra-tecal-MADIT

$>$ Consolidação de remissão: Ciclofosfamida, Ara-C, 6-Mercaptopurina (6-MP)

> Intensificação: Metotrexate, 6-MP, MADIT 
> Consolidação tardia: Dexametasona, Vincristina, Doxorrubicina, Asparaginase, Ciclofosfamida, 6-Tioguanina (6-TG), MADIT

> Manutenção: Grupo 1: 6-MP contínuo, pulsos de Vincristina e Dexametasona (até semana 78), MADIT-. Grupo 2: 6-MP intermitente, pulsos de Vincristina e Dexametasona, MADIT

\section{ESQUEMA PARA GRUPO DE ALTO RISCO:}

Indução: Grupo A: Dexametasona, Vincristina, Asparaginase, Daunorrubicina, MTX/Ara-C/Dexa Intra-tecal-MADIT

- Grupo B: Indução convencional $+\operatorname{MTX}(2$ doses $)$

- Bloco A: MTX 2g, 6-TG, Ara-C, Ciclofosfamida, MADIT

- Bloco B: Vincristina, MTX 2g, 6-MP, Ara-C, MADIT

Intensificação:

Dexametasona, VCR, Doxorrubicina, Asparaginase, Ciclofosfamida, 6TG, MADIT. Bloco C: MTX 2g, 6-MP, VP16, Ara-C- Bloco D: Ifosfamida, VP 16, MADIT

> Consolidação tardia: Dexametasona, Vincristina, Doxorrubicina, Asparaginase, Ciclofosfamida, 6-TG, MADIT

> Manutenção: 6-MP/MTX contínuo, pulsos de VCR/Dexa (até sem 78), MADIT

A intensidade e o uso das drogas são adaptados ao risco de recaída dos pacientes, analisado ao diagnóstico e nas primeiras semanas do tratamento. Embora existam diferenças, os critérios básicos para estratificação dos pacientes nos grupos de risco (contagem leucocitária e idade), são os propostos em 1993 pelo programa CTEP (Cancer Therapy Evaluation Program), uma iniciativa do National Cancer Institute, em conjunto com diversos grupos cooperativos de tratamento da LLA infantil (Smith et al., 1996).

No grupo de risco básico, são alocados os pacientes com idade entre 1 a 9 anos e com leucometria inicial inferior a $50.000 / \mathrm{mm}^{3}$. Os demais pacientes $(0-1$ ano e acima de 9 anos, com contagem leucocitária superior a 50.000/ $\mathrm{mm}^{3}$ ) são 
classificados como de alto risco. No entanto, esses dados clínicos e laboratoriais convencionais utilizados para definir a estratificação do tratamento nos diferentes grupos de risco, deixam de detectar 20-30\% dos pacientes, de início com bom prognóstico, e que recaem, apesar dos tratamentos padrões utilizados (Brandalise et al., 1993; Harris et al., 1998; Pui; Evans, 1998; Malempati et al., 2007).

Outros fatores prognósticos, que foram anteriormente descritos, como índice de DNA da célula leucêmica, anormalidades citogenéticas e imunofenótipo, também têm sido utilizados na estratificação dos pacientes nos grupos de risco. Além destes outro fator de extrema importância é a presença de doença residual mínima (DRM) (Greaves, 1997; Pui; Evans, 1998; Scrideli et al., 2009; Pui; Thiel, 2009).

Diversos trabalhos têm demonstrado que a resposta inicial ao tratamento, avaliada pela citorredução na medula óssea e/ou sangue periférico, é um fator prognóstico independente e fundamental na identificação de pacientes com maior ou menor risco de recaída (Schrappe et al., 1996; Steinherz et al., 1996; Aricó, 1997; Gaynon et al., 1997; Campana, 2008). Essa avaliação permite identificar o risco de recaída mesmo entre os casos com características desfavoráveis ao diagnóstico, como por exemplo, a leucemia aguda do lactente (Dordelmann et al., 1999), as leucemias T derivadas (Aricó et al., 1995) e as leucemias com presença da translocação t (9; 22) (Schrappe et al., 1998) (Campana, 2008).

A sensibilidade intrínseca das células leucêmicas à quimioterapia, que traduz a rapidez da morte celular, determina a capacidade da proliferação do tumor, a fase do ciclo celular dos blastos e também vai determinar a habilidade da terapia em alcançar concentrações suficientes, para a erradicação da doença (Steinherz et al., 
1996a; Steinherz et al., 1996b; Tsangaris et al., 1996; Di Tullio et al., 1998; Garami et al., 1999; Panzer-Grümayer et al., 1999; Campana, 2008).

Experimentos in vitro demonstram a importância da quimiossensibilidade da célula leucêmica na evolução clínica do paciente (Pieters et al., 1994; Kaspers et al., 1997). De certa maneira, ao analisar a velocidade da citorredução, faz-se indiretamente uma avaliação in vivo, tanto da sensibilidade intrínseca dessas células à quimioterapia, como da capacidade da terapia em alcançar os níveis plasmáticos e celulares das drogas citotóxicas (através da interação com o metabolismo do paciente) suficientes para a erradicação da doença (Evans et al., 1998).

\subsection{MECANISMOS DE RESISTÊNCIA AO TRATAMENTO}

Aproximadamente 70 a $80 \%$ das crianças com LLA sobrevivem após o tratamento quimioterápico, no entanto, apesar da porcentagem significativa do sucesso no tratamento da leucemia linfóide aguda, ainda existe um subgrupo de pacientes resistentes ao tratamento com a terapia convencional. Apesar dos avanços consideráveis obtidos no tratamento nas últimas décadas, 20 a 30\% dos casos ainda apresentam recidivas e as causas e mecanismos que levam ao insucesso do tratamento ainda precisam ser elucidados.

A resistência celular a drogas é um importante determinante de resposta à quimioterapia e caracteriza uma das barreiras mais significativas ao tratamento efetivo das neoplasias em geral (Brown, 1999; Kaspers; Veerman, 2003). 
Diversos eventos responsáveis pela resistência foram descritos nos últimos 40 anos e dentre eles a resistência múltipla a drogas, provocada pela expressão aumentada de P-glicoproteína (P-gp) é provavelmente a mais bem descrita da atualidade (Michieli et al., 2000; Brozek, et al., 2009).

O gene $M D R 1$, também chamado de P-170, pertence à superfamília de transportadores transmembrana (ATP-binding cassete) e codifica a P-gp. Essa proteína é capaz de aumentar o efluxo de um grande número de drogas e xenobióticos, reduzindo deste modo a concentração citotóxica intracelular. A proteína associada à resistência múltipla a drogas (MRP) também faz parte da superfamília de transportadores ligados ao ATP e confere resistência celular similar, embora não idêntica, ao espectro de drogas da P-gp. Atualmente, reconhece-se uma família de $M R P s$, que consiste em pelo menos seis homólogos (MRP1 a MRP6) e tanto a proteína MRP1 quanto seus homólogos MRP2, MRP3, MRP5 e MRP6 podem conferir resistência a drogas como daunorubicina, mitoxantrone, etoposido e 6mercaptopurina, frequentemente empregadas no tratamento da LLA em crianças (Sauerbrey et al., 2002; Van der Kolk et al., 2002, Brozek, et al., 2009).

Holleman e colaboradores (2004), através de microarranjos de oligonucleotídeos, determinaram uma série de genes cuja expressão está associada à resistência ou sensibilidade aos diferentes quimioterápicos normalmente utilizados na fase de indução (prednisona, vincristina, asparaginase e daunorrubicina), demonstrando que o padrão de expressão gênica (resistência versus sensibilidade às drogas) estava associado com a evolução clínica dos pacientes. Dentre os genes identificados, destacam-se os genes descritos na Tabela 1. 
Tabela 1. Genes associados à resistência/sensibilidade aos quimioterápicos identificados por Holleman e colaboradores (2004)

\begin{tabular}{|c|c|c|}
\hline Gene & Nome & Função gênica presumida \\
\hline $\begin{array}{l}\text { Vincristina } \\
R P L P 2\end{array}$ & Proteína Ribossomal P2 & $\begin{array}{l}\text { Ligante de RNA, participa do processo de } \\
\text { elongação durante a síntese protéica }\end{array}$ \\
\hline $\begin{array}{l}\text { CD44 } \\
\text { TCFL5 } \\
\text { KCNN1 }\end{array}$ & $\begin{array}{l}\text { Molécula CD44 (Indian blood group) } \\
\text { Fator de Transcrição like } 5 \text { protein } \\
\text { Canal condutor de potássio } 1\end{array}$ & $\begin{array}{l}\text { Colágeno -ligante e ácido hialurônico ligante } \\
\text { Fator de transcrição } \\
\text { Atividade de condução iônica; Calmodulina } \\
\text { ligante }\end{array}$ \\
\hline $\begin{array}{l}\text { TRIM24 } \\
\text { Prednisona }\end{array}$ & Tripartite motif-containing 24 & $\begin{array}{l}\text { Controle transcricional mediado por } \\
\text { interações com receptores nucleares como ác. } \\
\text { retinóico, vitamina D e estrógeno }\end{array}$ \\
\hline $\begin{array}{l}\text { F8A1 } \\
\text { CDK } 2 A P 1 \\
\text { BLVRB } \\
\text { CD69 }\end{array}$ & $\begin{array}{l}\text { Fator associado de coagulação VIII } \\
\text { Quinase } 2 \text { ciclina dependente } \\
\text { Biliverdina redutase B (flavina redutase) } \\
\text { Molécula CD69 }\end{array}$ & $\begin{array}{l}\text { Desconhecida } \\
\text { Regulação negativa da atividade de CDK2 } \\
\text { Atividade enzimática - Biliverdina redutase } \\
\text { Receptor transmembrana }\end{array}$ \\
\hline \multicolumn{3}{|c|}{ Daunorrubicina } \\
\hline MAP3К12 & Proteína quinase ativada por mitógeno & $\begin{array}{l}\text { Papel regulador na diferenciação neuronal } \\
\text { induzida por ácido retinóico }\end{array}$ \\
\hline $\begin{array}{l}\text { SHOC2 } \\
\text { PDCH9 } \\
\text { EGR1 } \\
\text { KCNN4 }\end{array}$ & $\begin{array}{l}\text { Soc-2 suppressor of clear homolog (C. elegans) } \\
\text { Protocaderina } 9 \\
\text { Early growth response protein } 1 \\
\text { Canal condutor de potássio } 4\end{array}$ & $\begin{array}{l}\text { Ativador da via RAS } \\
\text { Associado a transdução de sinais e conexões } \\
\text { neuronais } \\
\text { Fator de transcrição multifuncional } \\
\text { Canal de potássio }\end{array}$ \\
\hline \multicolumn{3}{|c|}{ L-Asparaginase } \\
\hline GPR56 & G protein-coupled receptor 56 & $\begin{array}{l}\text { Regulação do desenvolvimento cortical } \\
\text { cerebral }\end{array}$ \\
\hline MAN1A1 & Manosidose, alfa, classe $1 \mathrm{~A}$ & Catalisa a remoção de resíduos de manose \\
\hline CLEC11A & Domínio lectina tipo C, família 11 A & $\begin{array}{l}\text { Fator crescimento celular de progenitores } \\
\text { hematopoiéticos }\end{array}$ \\
\hline IGFBP7 & $\begin{array}{l}\text { Proteína ligante do fator de crescimento "insulin- } \\
\text { like" }\end{array}$ & $\begin{array}{l}\text { Proteína ligantensulin-like growth factor } \\
\text { binding }\end{array}$ \\
\hline GATA3 & Proteína ligante GATA3 & Fator de transcrição; \\
\hline
\end{tabular}

Ao contrário dos $20-30 \%$ dos pacientes resistentes à terapia convencional, existe também um subgrupo de pacientes que são muito sensíveis à terapia, demonstrando que o tratamento intensivo pode ter efeitos significativos por um longo período, incluindo a emergência de malignidades secundárias e de déficits 
no desenvolvimento. Sendo assim, a identificação de mecanismos biológicos que levam pacientes com LLA à recaída é um passo crítico para o desenvolvimento de estratégias alternativas para o tratamento de pacientes resistentes à terapia.

Apesar dos diversos fatores já identificados (idade, sexo dos pacientes, contagem leucocitária inicial, ploidia e imunofenótipo), os mecanismos moleculares relacionados com a resistência à terapia ainda são pouco conhecidos.

De acordo com os relatos da literatura, os genes acima descritos nunca foram associados ao processo de resistência e / ou sensibilidade aos quimioterápicos asparaginase, prednisona, daunorrubicina e vincristina até a descrição feita por Holleman et al., em 2004. Dessa maneira, a análise dos mesmos pode permitir uma melhor compreensão da fisiopatologia dos mecanismos leucemogênicos e auxiliar no estabelecimento de um diagnóstico mais preciso e orientar uma terapêtica mais adequada. Postulamos, portanto, que muitos desses genes, envolvidos com um padrão diferencial de expressão em resposta a diversas drogas, podem representar alvos importantes preditivos de resposta ao tratamento quimioterápico. 
Objetivos 


\section{OBJETIVOS}

\subsection{OBJETIVO GERAL}

$\checkmark \quad$ Avaliar o nível de expressão dos 19 genes previamente associados à resistência/sensibilidade aos quimioterápicos: prednisona, vincristina, asparaginase e daunorubicina em amostras de pacientes portadores de LLA tratados pelo protocolo GBTLI-99.

\subsection{OBJETIVOS ESPECÍFICOS}

$\checkmark \quad$ Analisar se há associação entre os níveis de expressão dos genes descritos e os parâmetros clínicos ao diagnóstico e durante a evolução clínica dos pacientes.

Avaliar a expressão do(s) gene(s) diferencialmente expresso(s) e com destacado potencial nos pacientes tratados pelo protocolo GBTLI-99 em amostras de LLA de pacientes submetidos ao protocolo de tratamento BFM-2002.

$\checkmark \quad$ Avaliar a expressão protéica do(s) gene(s) diferencialmente expresso(s).

$\checkmark \quad$ Realizar o silenciamento gênico e/ou a hiperexpressão gênica do(s) gene(s) diferencialmente expresso(s) e que apresentar (arem) destacado potencial como marcador prognóstico. 
Casuisticaue Métodos 


\section{CASUÍSTICA E MÉTODOS}

\subsection{CASUÍSTICA}

\subsubsection{Critérios de Inclusão e Exclusão}

Foram elegíveis para o estudo crianças e adolescentes com idade de zero a dezoito anos, de ambos os sexos, com diagnóstico de LLA (exceto o subtipo L3) diagnosticados e tratados uniformemente segundo as diretrizes estabelecidas pelo protocolo terapêutico do Grupo Brasileiro de Tratamento das Leucemias da Infância de 1999 (GBTLI-2000) entre o período de agosto de 2002 a outubro de 2005.

A casuística desse estudo foi composta de amostras de pacientes diagnosticados e tratados nas seguintes instituições: a) Hospital das Clínicas da Faculdade de Medicina de Ribeirão Preto da Universidade de São Paulo (HCFMRP-USP); b) Centro Infantil Boldrini (Campinas, SP) e c) Instituto de Oncologia Pediátrica da Universidade Federal de São Paulo (IOP-GRAACC-UNIFESP) (São Paulo, SP).

Além destes, também foram incluídos no presente estudo pacientes de LLA pertencentes ao grupo AIEOP (Associazione Italiana di Ematologia ed Oncologia Pediatrica) admitidos para tratamento no "Ospedale San Gerardo - Clinica Pediatrica. Fonzazione M. Tettamanti (Universita di Milano Biccoca)". Estes pacientes 
foram tratados segundo as diretrizes do protocolo Europeu BFM-2002 (“Berlim Frankfurt-Munster") e o projeto aprovado pelo comitê de ética e pesquisa do "Centro di Ricerca M. Tettamanti".

O material utilizado para a análise foi proveniente de amostras criopreservadas de medula óssea coletadas à ocasião do diagnóstico de LLA e o critério utilizado para inclusão no estudo foi a disponibilidade de amostra biológica (medula óssea ) coletada e devidamente criopreservada.

Todos os pacientes incluídos no estudo formalizaram a sua participação através da assinatura do "Termo de Consentimento Livre e Esclarecido" (Anexo A). O projeto foi aprovado pelo comitê de ética em pesquisa do HC-FMRP-USP (Anexo B: processo HCRP número 8681/2001).

Foram excluídos do estudo os pacientes cujas amostras coletadas apresentaram qualidade ou quantidade insatisfatória para a análise proposta e as crianças cujos pais ou responsáveis legais não concordaram em participar do estudo.

\subsubsection{Diagnóstico}

As amostras da medula óssea, na ocasião do diagnóstico de LLA, foram obtidas através de punção da crista ilíaca ou região pré-tibial e devidamente armazenadas, assim como as amostras de sangue periférico. $\mathrm{O}$ diagnóstico foi realizado através da análise do aspirado de medula óssea utilizando-se microscopia óptica, sendo confirmado pela presença de blastos linfóides em contagem superior a 25\% na medula óssea. 
A imunofenotipagem foi realizada nas respectivas instituições de origem por citometria de fluxo com anticorpos monoclonais. As leucemias de linhagem B foram subclassificadas em LLA pré-B precoce quando expressavam CD19 sem a presença de CD10; LLA comum (ou LLA CALLA positivo) quando apresentavam CD10; LLA Pré-B quando apresentavam imunoglobulina citoplasmática (cIg) sem a presença da imunoglobulina de superfície (sIg);e em LLA-B madura quando apresentavam imunoglobulina de superfície (sIg). Foram consideradas de linhagem $\mathrm{T}$ aquelas que apresentavam co-expressão de pelo menos dois marcadores associados a células T (CD7, CD5, CD3 e CD2).

A análise do cariótipo por bandamento $G$ foi realizada para a pesquisa de anormalidades cromossômicas do gene $M L L$ e do cromossomo Philadélfia. As translocações $\mathrm{t}(4 ; 11)(\mathrm{q} 21 ; \mathrm{q} 23)$ envolvendo os genes $M L L$ e AF4, TEL/AML1, BCR/ABLp190 e BCR/ABLp210 foram pesquisadas através de RT-PCR utilizando-se os primers propostos pelo European BIOMED-1 Concerned Action "Investigation of minimal residual disease in acute leukemia" (van Dongen et al., 1999).

Com relação à resposta ao tratamento, foram considerados bons respondedores aqueles pacientes com leucometria inferior a 5.000/mm3 no sétimo dia da indução, sem blastos periféricos detectáveis e que não apresentaram blastos no hemograma e no líquor (no caso deste ser positivo ao diagnóstico) no décimo quarto dia. Adicionalmente, devem apresentar medula óssea classificada como M1 (esfregaço medular contendo porcentagem de blastos inferior a 5\%) ou M2 (esfregaço medular contendo porcentagem de blastos entre 5 e 25\%) no décimo quarto dia da indução e medula M1 no vigésimo oitavo dia da indução (GBTLI, 2000). 
Como critérios para caracterização dos pacientes maus respondedores, foram considerados aqueles que apresentaram leucometria igual ou superior a 5.000/mm3 no sétimo dia da indução e/ou presença de blastos no sangue periférico ou líquor positivo no décimo quarto dia e/ou medula óssea classificada como M3 (esfregaço medular contendo porcentagem de blastos superior a $25 \%$ ) também no décimo quarto dia da indução e/ou no décimo oitavo dia com porcentagem de blastos maior que cinco por cento, independente da proporção de linfócitos maduros (GBTLI, 2000).

\subsubsection{Caracterização dos Pacientes}

Foram incluídas no estudo 201 amostras de pacientes com diagnóstico de LLA, sendo 141 tratadas pelo protocolo do GBTLI-99 e 60 tratadas pelo protocolo BFM-2002 (as quais apresentam as características clínicas descritas separadamente na Tabela 2). Foram analisados pacientes do Instituto Boldrini admitidos no período de agosto de 2002 a dezembro de 2004; pacientes do IOP-UNIFESP admitidos no período de janeiro de 2003 a dezembro de 2004 e do HC-FMRP-USP admitidos no período de dezembro de 2002 até outubro de 2005. A idade ao diagnóstico variou entre 8 a 214 meses (média de 80 meses).

Em relação ao imunofenótipo, 116 casos expressaram o antígeno CALLA (83\% dos casos). Quarenta e três casos (equivalente a 31\% dos casos analisados) apresentavam contagem de glóbulos brancos ao diagnóstico superior a $50.000 / \mathrm{mm} 3$. 
A pesquisa das translocações foi realizada nos pacientes provenientes do Instituto Boldrini e do HC-FMRP-USP (total de 92 pacientes dos 141 incluídos). Dentre estes, a translocação $t(4 ; 11)$ foi encontrada em apenas 4 pacientes do total pesquisado. A translocação TEL/AML1 foi detectada isoladamente em 19 casos e em 1 caso, em associação com a translocação t(9;22). A translocação $(9 ; 22)$ p190 foi encontrada isoladamente em 3 casos (3\% do total). Em 63 casos (ou 68\% do total de casos em que houve pesquisa de translocações) nenhuma das alterações genéticas pesquisadas foi encontrada.

Em relação ao tratamento foram considerados como sendo de alto risco para recidiva os pacientes que apresentaram pelo menos um dos seguintes critérios ao diagnóstico: idade igual ou superior a 9 anos ou inferior a 12 meses e/ou leucometria superior a $50.000 / \mathrm{mm}^{3}$. As crianças não portadoras de algum dos critérios acima mencionados foram consideradas como de baixo risco de recaída. Crianças inicialmente classificadas como sendo de baixo risco que apresentaram leucometria igual ou superior a 5.000/ mm3 no sétimo dia da indução e/ou presença de blastos no sangue periférico ou líquor positivo no décimo quarto dia e/ou medula óssea classificada como M3 (esfregaço medular contendo porcentagem de blastos superior a $25 \%$ ) também no décimo quarto dia da indução e/ou no décimo oitavo dia com porcentagem de blastos maior que cinco por cento foram reestratificados como de alto risco. Segundo esta estratificação de risco de recaída ao diagnóstico, a distribuição encontrada foi: $54 \%$ dos pacientes foram classificados como alto risco e $46 \%$ como baixo risco. Um dos pacientes foi inicialmente classificado como baixo risco e posteriormente realocado como alto risco devido à resposta insatisfatória. 
Ainda em relação à resposta, $85 \%$ dos pacientes apresentaram leucometria inferior a 5.000/ $\mathrm{mm}^{3}$ no sétimo dia da indução e, em 13 casos ela foi igual ou superior a este valor. Em $77 \%$ do total, a situação da medula óssea no décimo quarto dia da indução foi classificada como M1 ou M2, 11 casos foram avaliados como M3 (7\%) e em 21 casos não foram analisadas. No vigésimo oitavo dia da indução 128 casos apresentaram medula classificada como M1 (86\% dos casos), 8 casos apresentaram medula M2 ou M3 (6\%) e em 4 casos não havia dados disponíveis.

A presença de doença residual mínina foi avaliada no décimo quarto e no vigésimo oitavo dia após o início da indução da remissão, sendo considerada positiva nos pacientes que apresentaram clonalidade, para qualquer dos rearranjos analisados, na análise da medula no vigésimo oitavo dia.

A remissão clínica completa (RCC) foi definida como presença de quantidade inferior a 5\% de blastos leucêmicos na medula óssea, analisados por citologia convencional e ausência de sintomas ou sinais físicos atribuíveis à leucemia no vigésimo oitavo dia da indução (GBTLI, 2000). O tempo de remissão completa variou de 26 a 66 meses (mediana $=43$ meses). Trinta e dois pacientes (ou 22\% dos casos) apresentaram eventos desfavoráveis ao longo do período de observação verificado (cinco anos).

Em relação aos pacientes pertencentes à "Fondazione Tettamanti" estes foram divididos em três grupos: risco básico com boa resposta à prednisona, alto risco com boa resposta à prednisona e finalmente o grupo de maus respondedores. 
Cada um dos grupos é composto por 20 pacientes cujas características clínicas estão detalhadas na Tabela 2.

Tabela 2: Características Clínicas dos pacientes do grupo AIEOP

\begin{tabular}{lcc}
\hline Variáveis Clínicas & & N (\%) \\
\hline GD Diagnóstico & $<50.000$ & $47(78,3 \%)$ \\
& $>50.000$ & $13(21,7 \%)$ \\
Idade & $1-9$ anos & $46(76,7 \%)$ \\
\multirow{2}{*}{ Imunofenótipo } & $<1$ ou $>9$ anos & $14(23,3 \%)$ \\
\multirow{2}{*}{ Risco } & LLA B & $32(53,4 \%)$ \\
\multirow{2}{*}{ Resposta } & LLA pré B & $28(46,6 \%)$ \\
& AR & $40(66,6 \%)$ \\
DRM 33 & RB & $20(33,3 \%)$ \\
& Bom respond. & $40(66,6 \%)$ \\
Translocações & Mau respond & $20(33,3 \%)$ \\
\hline
\end{tabular}

\subsection{MATERIAIS E MÉTODOS}

\subsubsection{Coleta de Amostras}

As amostras de medula óssea foram coletadas em tubos de vidro Vacutainer ${ }^{\circledR}$ contendo EDTA e processadas conforme procedimento de rotina do laboratório de Oncologia Pediátrica do HC-FMRP-USP. Primeiramente, a medula óssea coletada foi transferida para tubo do tipo Falcon de $50 \mathrm{~mL}$ e lavada com $25 \mathrm{~mL}$ 
de solução de cloreto de amônio 0,144M e bicarbonato de amônio 0,01 M. Centrifugou-se a amostra a $4^{\circ} \mathrm{C}$ a $13.200 \mathrm{rpm}$ por 10 minutos, desprezando-se o sobrenadante. Ao final desta etapa, acrescentou-se $250 \mu \mathrm{L}$ de PBS. A seguir, adicionou-se TRIZOL LS Reagent® (Invitrogen, EUA) (na proporção de 3:1 de TRIZOL) homogeneizando com pipeta até lise completa das células. Após a permanência a temperatura ambiente por 5 minutos, o material foi estocado em alíquotas de $1 \mathrm{~mL}$ no freezer à $-80^{\circ} \mathrm{C}$.

\subsubsection{Extração de RNA}

Para o presente estudo, uma alíquota do material previamente processado como descrito acima foi manipulado como se segue. Acrescentou-se $200 \mu \mathrm{L}$ de clorofórmio ao tubo contendo a medula em TRIZOL®, agitando-se vigorosamente por 15 segundos. A solução final foi centrifugada a $4^{\circ} \mathrm{C}$ por 15 minutos (13.200 rpm) e a fase aquosa superior foi transferida para novos tubos devidamente identificados. O RNA foi precipitado com $500 \mu \mathrm{L}$ de álcool isopropílico $100 \%$ gelado e permaneceu à $-20^{\circ} \mathrm{C}$ por pelo menos 12 horas. Em seguida, centrifugou-se a amostra à $4^{\circ} \mathrm{C}$ por 20 minutos (13.200 rpm), desprezando a seguir o sobrenadante. Acrescentou-se $1 \mathrm{~mL}$ de etanol $75 \%$ seguido novamente de centrifugação refrigerada por 5 minutos . Desprezou-se a fase superior e dissolveu-se o pellet seco em água tratada com DEPC (dimetil pirocarbonato) por 15 minutos. Em seguida o material foi quantificado por meio do espectofotômetro Gene Quant (GE Life Science, USA) aliquotado e armazenado a $-80^{\circ} \mathrm{C}$. 


\subsubsection{Síntese de DNA complementar (cDNA)}

Para a síntese de cDNAs utilizou-se o kit "High Capacity cDNA arquive set" (Applied Biosystems, USA) segundo protocolo de instruções do fabricante. As reações foram padronizadas para um volume final de $25 \mu \mathrm{l}$ e utilizou-se $1 \mu \mathrm{g}$ de RNA para cada reação. A solução permaneceu a $25^{\circ} \mathrm{C}$ o por 10 minutos e em seguida mantida a $37^{\circ} \mathrm{C}$ por duas horas. As alíquotas de cDNA foram armazenadas em freezer a $-20^{\circ} \mathrm{C}$.

\subsubsection{Controle Endógeno}

Como controle endógeno foi utilizado o gene GUSB, tanto para avaliar a integridade das amostras de cDNA sintetizadas, como também para a normalização dos níveis de expressão dos genes estudados. O gene GUSB, que codifica a proteína beta-glucoronidase, apresenta níveis constantes de expressão em diferentes tipos celulares, não apresenta pseudogenes e não interfere no processo de ativação do ciclo celular, o que o torna uma boa escolha como controle endógeno. Além disso, o mesmo foi considerado por Beillard e colaboradores (2003) um "housekeeping" apropriado para estudos de leucemia.

Para avaliar a integridade das amostras de cDNA, realizou-se a reação de RT-PCR para o gene GUSB de acordo com o protocolo descrito a seguir: foi utilizado 1,0 $\mu \mathrm{L}$ de cDNA adicionado a uma solução contendo $0,5 \mu \mathrm{L}$ de solução 10mM de cada dNTP, 0,75 $\mu \mathrm{L}$ de cloreto de magnésio $50 \mathrm{nM}$ (Invitrogen, Brasil), 2,5 
$\mu \mathrm{L}$ de solução tampão 5X (Invitrogen), 15 pmoles de cada primer (antisense e sense), 0,2 $\mu \mathrm{L}$ de Taq-polimerase $5 \mathrm{U} / \mu \mathrm{L}$ (Platinum Taq DNA polymerase; Invitrogen). A reação de PCR foi padronizada em estudo-piloto para definição das melhores condições de desnaturação, anelamento e amplificação. As condições finais para a reação de RT-PCR foram as que se segue: desnaturação inicial a $94^{\circ} \mathrm{C}$ por 4 minutos e pareamento a $60^{\circ} \mathrm{C}$ por 2 minutos, seguido de 38 ciclos de desnaturação à $94^{\circ} \mathrm{C}$, pareamento à $60^{\circ} \mathrm{C}$ e extensão à $72^{\circ} \mathrm{C}$ por 1 minuto cada, seguidos de um ciclo de extensão final à $72^{\circ} \mathrm{C}$ por 10 minutos, realizadas em um termociclador PTC-200 (MJ Research, Inc, EUA). Os produtos de PCR foram submetidos à eletroforese em gel de agarose a $2 \%$ com brometo de etídeo juntamente com um controle negativo e visualizado através do transluminador com luz ultravioleta. A seqüência de primers do gene GUSB utilizada no presente estudo está descrita na Tabela 3. Somente as amostras de medula óssea que apresentaram amplificação para este gene foram estudadas.

\subsubsection{Seleção dos Primers}

Os genes utilizados no presente estudo foram escolhidos a partir dos dados descritos por Holleman et al., (2004); o critério de escolha foi baseado na razão R/S (resistentes/sensíveis) e consistiram em dois genes de sensibilidade e três de resistência para cada um dos quimioterápicos analisados. Os primers gene específicos utilizados foram construídos em éxons diferentes (exceto para o F8A que possui apenas um éxon) em regiões não sujeitas a splicing alternativo e sem polimorfismos descritos, com base nas sequências descritas no blast 
(www.ncbi.nlm.nih.gov/BLAST) e ensembl (www.ensembl.org), através do programa Oligo 3.0 (Whitehead Institute/;MIT Center for Genome Research).

O desenho dos primers foi realizado em éxons diferentes para se evitar a contaminação com o DNA genômico e também para que as formas derivadas de splicings alternativos também sejam englobadas na análise. Como características eles possuem tamanho variando de 18-22 pb, temperatura de anelamento em torno de $60^{\circ} \mathrm{C}$ (aceitável de $57-63^{\circ} \mathrm{C}$ ), conteúdo em GC entre 40-65\%, sem repetições seguidas de $C$ ou G maiores que $4 \mathrm{pb}$. Para o gene GUSB foram utilizados os primers descritos anteriormente por Beillard et al., (2003).

Os primers (descritos na Tabela 3) foram checados para especificidade no ensembl (URL: http://www.ensembl.org) e Basic Local Alignment Search Tool BLAST, sendo que todos se mostraram específicos para os respectivos genes. 
Tabela 3: Sequência dos primers utilizados

\begin{tabular}{|c|c|c|}
\hline Gene & Forward primer $\left(5^{\prime} \rightarrow 3^{\prime}\right)$ & Reverse primer $\left(5^{\prime} \rightarrow 3^{\prime}\right)$ \\
\hline \multicolumn{3}{|l|}{ Vincristina } \\
\hline RPLP2 & ACGTACTTGCCCAGGGTAT & GCAGCAGAGACGGCTACAG \\
\hline$C D 44$ & AGAAGGTGTGGGCAGAAGAA & ACTTGGCTTTCTGTCCTCCA \\
\hline TCFL5 & GAGAGGCATAACCGAATGGA & TGCAGAACGGCACTAAGAGA \\
\hline KCNN1 & TTCAGCATCTCCTCCTGGAT & GCTGGTCACTTCCTGCTTGT \\
\hline TRIM24 & CTGAGGTTCCCAGCAGTACA & ACACGTCTTGCAGAGCCATT \\
\hline \multicolumn{3}{|l|}{ Prednisona } \\
\hline$F 8 \mathrm{~A}$ & CTTCCCGAGGAGCTCTTTCT & GTGGGTAGCCATGACCAAAG \\
\hline$C D K 2 A P 1$ & GAAGAGCTGGGGAAGGAGAT & GCAGCTAGGATCTGGCATTC \\
\hline$B L V R B$ & CCTGAAGTACGTGGCTGTGA & CCCAGGTCATGTTTGGAGAT \\
\hline CD69 & AGGAACACTGGGTTGGACTG & CATGCTGCTGACCTCTGTGT \\
\hline \multicolumn{3}{|c|}{ Daunorrubicina } \\
\hline МАР3К12 & GGTGTGGGAAGCAACAGTCT & GCGATTTCGTGGTTTGCTAT \\
\hline SHOC2 & TGCTTAGCATTCGAGAGAACAA & TGTGAGCTACATCCAGCGTAA \\
\hline PCDH9 & CCAAGGAGGCTTCAAGACAA & GAGCCATCAGGGAGATGAAA \\
\hline EGR1 & TGACCGCAGAGTCTTTTCCT & GCGATTTCGTGGTTTGCTAT \\
\hline KCNN4 & CGGGAACAAGTGAACTCCAT & CCAGCGTGTCAATCTGTTTC \\
\hline \multicolumn{3}{|c|}{ L-Asparaginase } \\
\hline GPR56 & TCAGCCAGTTCCTGAAGCAT & СТCCTCGAAGGACACCATGT \\
\hline MAN1A1 & GGCCCAACACTACCTTGAAC & TGTAGCGATGGCTTCAACAC \\
\hline CLEC11A & TTGGAGGGCTGCCTGAAG & CGAGAGCAGGAAGCACTTGT \\
\hline IGFBP7 & GGGTCACTATGGAGTTCAAAGG & GCATGGCACTCATATTCTCCA \\
\hline GATA3 & CCGCCCTACTACGGAAACTC & CAGGGTAGGGATCCATGAAG \\
\hline \multicolumn{3}{|c|}{ House keeping } \\
\hline GUSB & GAAAATATGTGGTTGGAGAGCTCATT & CCGAGTGAAGATCCCCTTTTTA \\
\hline
\end{tabular}

\subsubsection{PCR Quantitativo em Tempo Real (RQ-PCR)}

3.2.6.1 Construção de curvas-padrão

Para se estimar a eficiência da reação de PCR, foram construídas curvas-padrão baseadas em diluições seriadas de uma amostra padrão. Esse padrão 
foi obtido através de plasmídeos purificados contendo a sequência alvo de cada um dos genes a serem analisados no estudo. Para a construção dos plasmídeos foi utilizada a tecnologia TOPO TA Cloning® Kits (Invitrogen) segundo as instruções do fabricante (Anexo C). A eficiência das reações foi calculada a partir do valor de slope obtido, através da formula:

$$
E=10(-1 / \text { inclinação da curva) }-1
$$

Todas as reações de PCR consideradas obtiveram eficiência igual ou superior a $95 \%$.

\subsubsection{Condições padronizadas para as reações de RQ-PCR}

Para a determinação do nível de expressão do RNAm dos genes alvo e do gene de referência endógena GUSB foi utilizada a da técnica de PCR em tempo real (RQ-PCR) utilizando os reagentes SYBR Green I e também sondas fluorescentes provenientes do sistema UPL (Universal Probe Library - Roche Applied). Todas as reações foram realizadas no aparelho $A B I$ 7500® (PE Applied Biosystems).

As reações foram preparadas utilizando-se SYBR Green PCR Master Mix (Applied Biosystems) contendo SYBR Green dye, AmpliTaq Gold DNA Polimerase, dNTPs (com dUTP), referência passiva e tampão otimizado. O preparo das reações foi realizado segundo as instruções do fabricante e para cada reação foram utilizadas amostras de cDNA em diluições de 1:10. Utilizou-se para o preparo de todas as reações, placas de polipropileno para 96 reações (ultraAmp 96-well Semi-Skirt PCR 
plates, Sorenson BioScience, Inc.) cobertas com adesivos para microplacas resistente a álcool e altas temperaturas (Adhesive PCR Film, ABgene).

Os parâmetros do aparelho foram ajustados para pré-aquecimento inicial a $50^{\circ} \mathrm{C}$ por 2 minutos, desnaturação a $95^{\circ} \mathrm{C}$ por 10 minutos e 50 ciclos de amplificação e quantificação $\left(15\right.$ segundos a $95^{\circ} \mathrm{C}$ e 60 segundos a $60^{\circ} \mathrm{C}$ ), seguidos de um período de dissociação para análise da curva de melting de 60 segundos a $95^{\circ} \mathrm{C}$.

Cada amostra analisada foi testada em duplicata, além de um calibrador e controles negativos referentes a cada um dos genes analisados. Além disso, foram realizadas curvas de dissociação para todas as reações para verificar a especificidade dos produtos amplificados. A figura 1 exemplifica os gráficos de amplificação e dissociação obtidos para uma das amostras de LLA analisadas.
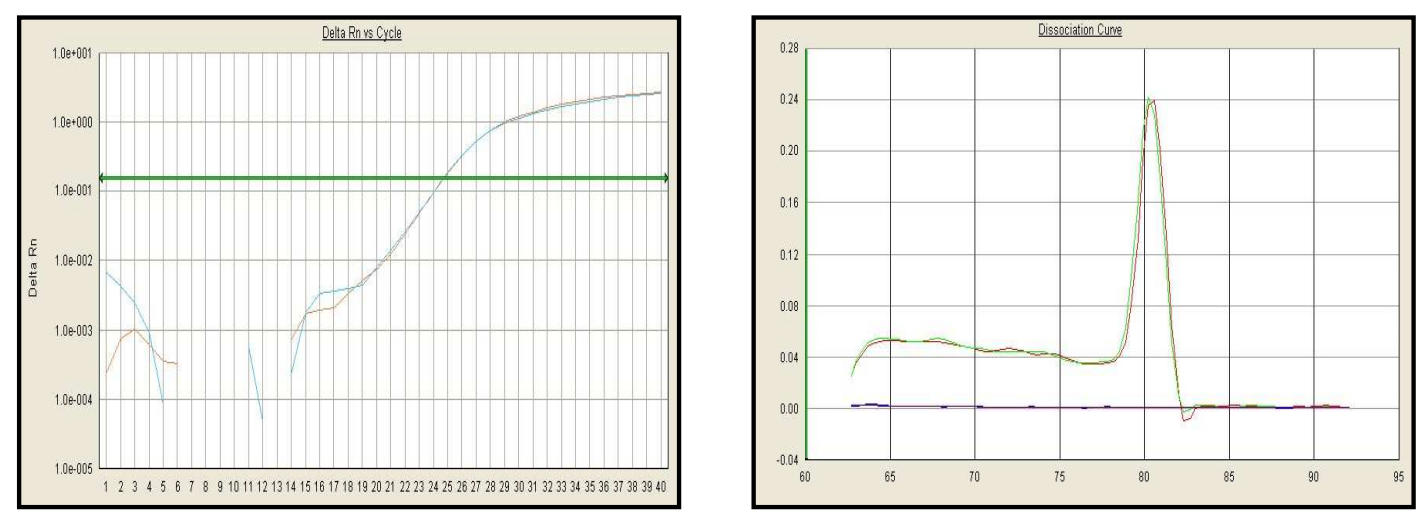

Figura 1. Curva de amplificação e dissociação da amostra LE4/0053 para o gene SHOC2

Para as amostras de LLA admitidas para tratamento na "Fondazione Tettamantti - Ospedale San Gerardo, Universita di Milano, Biccoca", a análise do perfil de expressão gênica foi realizada utilizando-se a técnica UPL (Universal Probe Library). Essa tecnologia é baseada em pequenas sondas hidrolisadas que são marcadas com 
um fluoróforo (FAM) na extremidade $5^{\prime}$ e com um quencher dye na extremidade $3^{\prime}$. A extensa cobertura de transcrição pelas sondas UPL ocorre devido à sua pequena extensão (8-9 nucleotídeos) e por suas sequências selecionadas. Para manter a especificidade e a temperatura de melting (Tm) necessária, os LNA (Locked nucleic acids) são incorporados em cada sequência das sondas universais. As seqüências das 165 sondas universais são cuidadosamente selecionadas para detectar de 8-9 mermotifs que são prevalentes no transcriptoma (Figura 2).

No transcriptoma humano, cada sonda se liga a aproximadamente 7000 transcritos, e cada um desses transcritos é detectado por aproximadamente 16 sondas diferentes. Apenas um único transcrito é detectado em um tempo determinado durante a PCR, de acordo com a definição dos primers selecionados. Para cada ensaio de PCR, um software sugere um set de primers ótimo para a reação e também a sonda. A sequência dos primers utilizados e suas respectivas sondas estão descritos na Tabela 4.

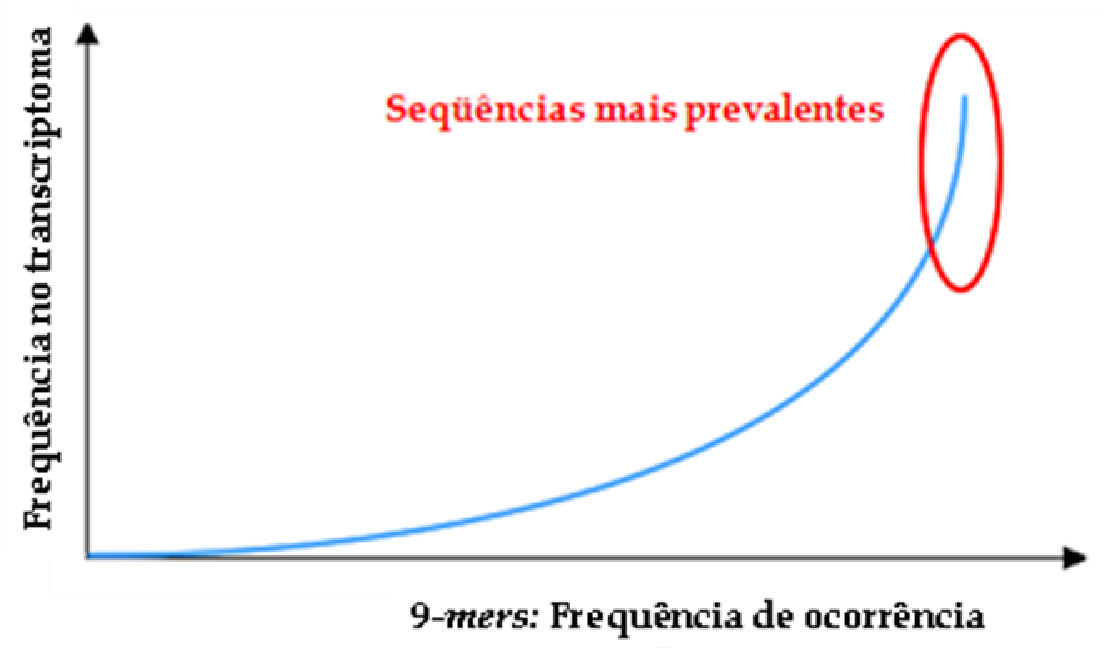

Figura 2. Frequência das sequências 9-mers mais prevalentes incluídas na "Universal Probe Library". Fonte: https://www.roche-applied-science.com/sis/rtpcr/upl/index 
Tabela 4: Sequência de primers e suas respectivas sondas

\begin{tabular}{llc}
\hline & Primers & Sonda \\
SHOC2 & TGCTTAGCATTCGAGAGAACAA-F & $\# 62$ \\
& TGTGAGCTACATCCAGCGTAA-R & \\
GPR56 & TCAGCCAGTTCCTGAAGCAT-R & $\# 13$ \\
& CTCCTCGAAGGACACCATGT-F & \\
\hline
\end{tabular}

\subsubsection{Quantificação da Expressão Gênica}

A quantificação da expressão gênica avaliada neste estudo foi baseada na metodologia de quantificação relativa, onde se pode inferir a expressão gênica do gene alvo em relação a um calibrador pré determinado. Foram utilizadas como parâmetro de expressão (calibrador) amostras de medula óssea provenientes de pacientes pediátricos não oncológicos. Somente foram consideradas para a análise as amostras cuja diferença de amplificação entre as duplicatas não excedesse um desvio padrão no valor de 0.4 (Van der Velden et al., 2003).

Para o cálculo da expressão gênica dos genes estudados foi utilizado o método de quantificação 2- $\Delta \Delta$ Ct (Livak; Schimittgen, 2001). Os dados foram analisados através da equação:

$$
\text { Quantificação relativa }=2^{-\Delta \Delta C t}
$$

Onde $\Delta \Delta \mathrm{Ct}=\Delta \mathrm{Ct}_{\text {gene de referência }}-\Delta \mathrm{C} \mathrm{t}_{\text {gene alvo }}$ 


\subsubsection{Análise da expressão proteica - Western Blotting}

\subsubsection{Extração de proteínas}

A extração de proteínas das amostras de LLA foi realizada de acordo com as instruções do fabricante (TRIZOL $®$, Invitrogen), modificada como descrito a seguir: Adicionou-se $200 \mu \mathrm{L}$ de solução de lise (Tris-Base 10mM, uréia 7,7M, tiouréia 2.2M, CHAPS 4.4\%) e coquetel de inibidores de proteases (na proporção de $10 \%$ em relação ao volume do tampão de lise) ao pellet seco, após a extração de RNA e DNA. Foram realizados 3 ciclos de 5' no sonicador seguidos de 15 segundos no vortex e, em seguida, as amostras foram congeladas em nitrogênio líquido por 10 segundos. Posteriormente o lisado foi centrifugado a $12.000 \mathrm{rpm}$, a $4^{\circ} \mathrm{C}$ por 30 minutos. $\mathrm{O}$ sobrenadante correspondeu ao extrato protéico que por sua vez foi congelado a $-80^{\circ} \mathrm{C}$ em alíquotas para posterior quantificação das proteínas totais.

Para a extração de proteínas das amostras da linhagem celular Jurkat (Linhagem proveniente de leucemia de células $\mathrm{T}$ ), foi utilizado o tampão de lise RIPA ${ }^{\circledR}$ (Pierce) juntamente com inibidor de proteases seguindo-se as recomendações do fabricante. Posteriormente a concentração de proteínas foi determinada pelo método de Bradford (1976). Uma solução de soro albumina bovina (BSA, 0,1 $\mathrm{mg} / \mathrm{mL}$ ) foi utilizada como padrão. Os valores de absorbância foram obtidos através da leitura em espectrofotômetro (leitor de microplacas) utilizando-se o comprimento de onda de $595 \mathrm{~nm}$. 


\subsubsection{Western Blotting}

A metodologia utilizada foi seguida de acordo com Sambrook e colaboradores (1989). Massas iguais de proteínas totais $(50 \mu \mathrm{g})$ foram aplicadas em gel de poliacrilamida-SDS 10\%, utilizando-se o sistema Mini Protean II Dual Slab Cell (Bio-Rad, EUA). Em seguida, iniciou-se a corrida em condições constantes de voltagem $(80 \mathrm{~V})$ e variável de miliamperagem (15 a $45 \mathrm{~mA})$. Após a separação protéica, deu-se início à transferência (por uma hora, 100 V, 250 mA) para membrana de nitrocelulose onde se utilizou o sistema Mini transblot electrophoretic transfer cell (Bio-Rad ou GE, EUA) imerso em gelo. Após a transferência, as membranas foram coradas em solução de Ponceau S, para verificação da qualidade do processo. Em seguida, as membranas foram lavadas em tampão Tris/salinatamponada/ Tween-20 (TBST) e bloqueadas com solução TBST/Non-fat dry milk 5\% por uma hora, sob agitação constante. As soluções utilizadas estão descritas no anexo C.

Posteriormente, iniciou-se o processo de imunodetecção através da incubação com o anticorpo primário adequado (Anti-SHOC2 1:1000, ABCam, EUA), diluído em TBS-TWEEN $20(0.1 \%)$ por uma hora. Em seguida foram feitas três lavagens em TBS-T para a retirada do excesso de anticorpo primário e em seguida a incubação com o anticorpo secundário adequado (Anti-rabbit 1:25000, Chemicon, EUA, conjugado a uma enzima horseradish peroxidase) por uma hora. Para a detecção da proteína de referência utilizou-se anticorpo primário para GADPH (1:1000, Santa Cruz Biotechnology, EUA) e o anticorpo secundário adequado (Anti-mouse conjugado com peroxidase, 1:5000, Amersham Bioscience, EUA). A revelação foi 
realizada através do emprego do substrato quimioluminescente ECL (Amersham, EUA) e de filmes de raios-x ultra-sensíveis (Hyperfilm Amersham, GE Healthcare, EUA). Os filmes foram expostos às membranas utilizando um tempo de exposição inicial de 30 segundos.

\subsubsection{Silenciamento por RNA de interferência (RNAi)}

\section{Linhagens celulares e condições de cultivo}

Foi utilizada a linhagem Jurkat, cultivada em meio RPMI suplementado com $1 \%$ de glutamina, $100 \mathrm{mg} / \mathrm{ml}$ de estreptomicina, $100 \mathrm{U} / \mathrm{ml}$ de penicilina, e $10 \%$ de soro fetal bovino ( $\mathrm{pH} 7,2-7,4)$ em atmosfera úmida contendo $5 \% \mathrm{CO}_{2}$ a $37^{\circ} \mathrm{C}$. Para produzir o silenciamento gênico foram utilizados oligômeros silencer ${ }^{\circledR}$ pré designed and validated siRNA específico para o gene SHOC2 e como controle foi utilizado o silencer ${ }^{\circledR}$ negative \#1 siRNA. O duplex de siRNA (previamente validado pelo fabricante) foi obtido através da Ambion (Applied Biosystems, EUA) e diluído de acordo com as instruções do fabricante. Após atingirem a concentração de aproximadamente $1,0 \times 10^{6}$ células $/ \mathrm{mL}$ a suspensão celular foi centrifugada e posteriormente ressuspendida em meio RPMI suplementado com $10 \%$ de soro bovino fetal e sem antibióticos. $1 \times 10^{6}$ células foram incubadas em placas de 6 poços e mantidas a $37^{\circ} \mathrm{C}$ em atmosfera úmida contendo $5 \%$ de $\mathrm{CO}_{2}$ por 24 horas (antecedentes à transfecção).

A transfecção com siRNA para silenciamento do gene SHOC2, assim como do siRNA utilizado como controle negativo, foi realizada utilizando-se Lipofectamina 2000 (Invitrogen Inc, Carsdab, CA) segundo instruções do fabricante. 
A lipofectamina e o siRNA foram diluídos separadamente em meio Opti-MEM® (Invitrogen, EUA) e após incubação de 30 minutos. Segue-se então outro período de incubação de 20 minutos e em seguida o complexo foi adicionado à suspensão celular. As placas foram incubadas por 6 horas (tempo suficiente para a transfecção) e posteriormente seguiram-se as análises nos tempos subsequentes $(24,48,72$ e 96 horas após a transfecção). O silenciamento específico do gene alvo foi confirmado pela análise da expressão gênica por RT-PCR em tempo real e por análise da expressão protéica por Western Blotting.

\subsubsection{Ensaios Funcionais}

\section{Ensaio de Proliferação Celular}

A proliferação celular foi avaliada através do ensaio com 3-(4,5dimetitiazol-2)-2,5-difeniltetrazolium. Para detectar o efeito do silenciamento gênico, a massa de células viáveis foi medida utilizando-se o ensaio colorimétrico Cell Proliferation Kit II XTT (Roche Applied Science, Mannheim Germany). 5 x $10^{3}$ células da suspensão da linhagem de leucemia (Jurkat) foram semeadas em triplicata em placas de 96 poços e colocadas para crescimento por 24, 48, 72 e 96 horas. Para cada intervalo, foi adicionado o reagente 3-(4,5-dimetitiazol-2)-2,5-difeniltetrazolium e nova incubação por 4 horas para permitir o aparecimento de cor na solução. A absorbância foi lida em $450 \mathrm{~nm}$ e com referência em 620nm e o valor obtido foi comparado entre o grupo de células silenciadas e as células não silenciadas. A porcentagem de inibição da proliferação devido ao silenciamento por RNAi foi 
calculado através da subtração da taxa de proliferação das células não silenciadas e a taxa de proliferação das células silenciadas.

\section{Ensaio de Apoptose}

Para o ensaio de apoptose foi coletado em um tubo de microcentrífuga $100 \mu \mathrm{L}$ de suspensão celular com $2 \mu \mathrm{L}$ da solução de corantes: $25 \mu \mathrm{L}$ de Iodeto de

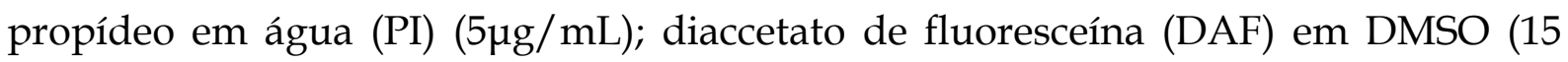
$\mu \mathrm{g} / \mathrm{mL})$; Hoecchst 33342 (HO) em água $(2 \mu \mathrm{g} / \mathrm{mL})$. A suspensão foi incubada em banho-maria a $37^{\circ} \mathrm{C}$ por 5 minutos. Deste material, foi coletado $15 \mu \mathrm{L}$ e colocado em lâmina com lamínula. As células apoptóticas foram contadas utilizando microscópio de epifluorescência com filtro triplo (DAPI, propídeo e FITC). Foram analisadas 500 células por lâmina, discriminando-se células normais das apoptóticas e necróticas de acordo com os seguintes critérios:

1) Células normais: núcleo íntegro corado em azul e citoplasma verde.

2) Células apoptóticas: núcleo azul com corpos apoptóticos e citoplasma verde.

3) Células necróticas: núcleo vermelho íntegro, esférico ou em vesículas.

\subsection{Análise Estatística}

Para a para avaliação de associação estatística entre níveis de expressão dos genes estudados e as variáveis clínicas e biológicas (idade ao diagnóstico, contagem inicial de glóbulos brancos, presença de alterações $M L L / A F 4$ e $B C R / A B L$ presença da translocação TEL/AML1, presença do antígeno de superfície CALLA, 
contagem de glóbulos brancos no sangue periférico no sétimo dia da indução, avaliação de medula óssea no décimo quarto e vigésimo oitavo dias da indução e doença residual mínima no vigésimo oitavo dia da indução), utilizou-se o teste de Mann-Whitney.

A presença de correlação entre os valores de expressão dos genes foi analisada pelo teste de Spearman.

Para o grupo de pacientes de mesma classificação de risco e variantes clínicas e biológicas e, alta ou baixa expressão dos diversos genes analisados foram construídas curvas de sobrevida livre de evento (SLE) através do método de KaplanMeier. A comparação entre as curvas foi realizada pelo teste log-rank. Foram considerados como aumentados os valores de expressão acima da mediana.

A SLE foi calculada considerando-se o tempo decorrido desde o início do tratamento até a ocorrência da primeira recidiva, falha indutora ou óbito (GBTLI, 2000). Os dados referentes à SLE foram atualizados em março de 2009.

Para os ensaios funcionais, realizou-se o experimento em triplicata e foi utilizada a média dos mesmos para a análise final através do teste T de Student.

As análises estatísticas foram realizadas com o auxílio do programa estatístico SPSS 15.0 for Windows (SPSS Inc, Chicago, EUA). A significância estatística foi adota através de um valor de $\mathrm{p} \leq 0,05$. 
Resultados 


\section{RESULTADOS}

\subsection{ANÁlisE DE EXPRESSÃO GÊNICA - Genes envolvidos com resistência/ sensibilidade a quimioterápicos em pacientes portadores de LLA submetidos ao protocolo do GBTLI-99}

Foram considerados como hiperexpressos os genes que apresentaram valores de expressão acima da mediana e como hipoexpressos aqueles que apresentaram valores abaixo da mediana. A correlação entre os níveis de expressão dos genes estudados foi avaliada pelo teste de correlação de Spearman. A comparação entre os valores de expressão dos genes e as variáveis clínicas: idade (entre 1-9 anos versus <1 ano/>9 anos), número de glóbulos brancos ao diagnóstico (maior ou menor que 50000/ $\mathrm{mm}^{3}$ ) e no dia 7 (maior ou menor que $5000 / \mathrm{mm}^{3}$ ), status da medula óssea nos dias 14 (M1/M2 vs M3) e 28 (M1 vs M2/M3), resposta (boa ou lenta), grupo de risco, imunofenotipagem (pré-B CALLA positivo versus outros), presença de cariótipo desfavorável $[\mathrm{t}(9 ; 22)$ ou $\mathrm{t}(4 ; 11)]$ e evento (morte/recidiva vs remissão completa) foi realiza pelo teste não paramétrico de Mann-Whitney. A sobrevida livre de eventos em 5 anos foi realizada utilizando-se curvas de KaplanMeier e o teste Log-rank.

Análise de expressão foi realizada em 141 pacientes para os genes descritos na tabela abaixo (Tabela 5). Os valores de média, desvio padrão, mediana e percentís dos genes analisados estão demonstrados na Tabela 6. 
Tabela 5 - Genes de resistência/sensibilidade a quimioterápicos

\begin{tabular}{lcccc}
\hline & Prednisona & Vincristina & Asparaginase & Daunorrubicina \\
\hline Sensibilidade & $F 8 A$ & RPLP2 & GPR56 & MAP3K12 \\
& CDK2AP1 & CD44 & MAN1A1 & SHOC2 \\
\hline Resistência & BLVRB & TCFL5 & CLEC11A & PCDH9 \\
& CD69 & KCNN1 & IGFBP7 & EGR1 \\
& & TRIM24 & GATA3 & KCNN4 \\
\hline
\end{tabular}

Tabela 6 - Valores de média e desvio padrão, mediana e percentís dos genes analisados.

\begin{tabular}{lcccccccc}
\hline & & Média & $\begin{array}{c}\text { Desvio } \\
\text { Padrão }\end{array}$ & Mínimo & Máximo & \multicolumn{3}{c}{ Percentís } \\
& $\mathrm{N}$ & & & & & $\mathbf{2 5} \%$ & Mediana & $\mathbf{7 5 \%}$ \\
\hline BLVRB & 141 & 1,8726 & 8,28946 & 0 & 87,13 & 0,0515 & 0,168 & 0,5415 \\
CD44 & 141 & 2,0397 & 3,85632 & 0,02 & 31,2 & 0,3635 & 0,857 & 1,837 \\
CD69 & 141 & 7,4807 & 12,1469 & 0,01 & 75,78 & 0,5986 & 2,752 & 10,9475 \\
CDK2AP1 & 141 & 4,0595 & 3,93074 & 0,05 & 23,99 & 1,536 & 2,693 & 5,191 \\
F8A & 141 & 7,4075 & 17,28066 & 0,03 & 124,7 & 0,9795 & 2,306 & 4,9205 \\
KCNN4 & 141 & 1,2863 & 2,15002 & 0 & 15,07 & 0,2035 & 0,537 & 1,436 \\
MAP3K12 & 141 & 6,5411 & 16,82322 & 0 & 127,62 & 1,2545 & 2,589 & 4,917 \\
PCDH9 & 141 & 10,1933 & 17,70961 & 0 & 91,84 & 0,377 & 3,175 & 10,012 \\
SHOC2 & 141 & 1,6036 & 1,81335 & 0,01 & 10,18 & 0,631 & 1,093 & 1,824 \\
GATA3 & 140 & 1715,782 & 20252,90672 & 0 & 239639,52 & 0,102 & 0,3285 & 1,7613 \\
GPR56 & 140 & 39,7083 & 378,27382 & 0 & 4454,18 & 0,5125 & 1,834 & 7,3045 \\
IGBP7 & 140 & 2,8933 & 8,37949 & 0 & 81,78 & 0,2475 & 0,926 & 2,138 \\
KCNN1 & 140 & 0,0024 & 0,01495 & 0 & 0,14 & 0 & 0 & 0,0001 \\
MAN1A1 & 140 & 5,1116 & 40,69211 & 0 & 482,32 & 0,3772 & 0,7785 & 2,118 \\
RPLP2 & 140 & 2,6761 & 13,35418 & 0,01 & 125,28 & 0,348 & 0,592 & 0,8425 \\
CLEC11A & 140 & 2,5783 & 11,29345 & 0 & 112,81 & 0,161 & 0,5345 & 1,309 \\
TCFL5 & 140 & 15,9418 & 56,96099 & 0 & 586,47 & 1,1628 & 3,039 & 12,7305 \\
TRIM24 & 140 & 3,1913 & 8,07156 & 0 & 81,63 & 0,8703 & 1,6075 & 2,6948 \\
\hline
\end{tabular}

A análise de comparação entre a contagem inicial de glóbulos brancos e o perfil de expressão dos genes analisados mostrou correlação estatística para os genes BLVRB, IGFBP7 e GPR56. O grupo de pacientes que apresentou, ao diagnóstico, contagem de glóbulos brancos superior a 50.000/ $\mathrm{mm}^{3}$ apresentou valores de expressão significativamente superiores $(p \leq 0,05)$ em relação ao do grupo de pacientes com contagem inferior a este valor. Os dados estão descritos na tabela 7. 
Tabela 7. Expressão relativa dos genes analisados em relação à contagem de glóbulos brancos ao diagnóstico.

\begin{tabular}{cccccc}
\hline Gene & $\begin{array}{c}\text { GB } \\
\text { diagnóstico }\end{array}$ & Média & Mediana & $\begin{array}{c}\text { Desvio } \\
\text { padrão }\end{array}$ & p \\
\hline GPR56 & $<50.000 / \mathrm{mm}^{3}$ & 51,5150 & 1,4830 & 456,67867 & \\
& $\geq 50.000 / \mathrm{mm}^{3}$ & 17,7169 & 3,3880 & 77,73198 & $\mathbf{0 , 0 0 9}$ \\
BLVRB & $<50.000 / \mathrm{mm}^{3}$ & 2,0761 & 0,2120 & 9,34407 & \\
& $\geq 50.000 / \mathrm{mm}^{3}$ & 1,4553 & 0,0740 & 5,39721 & $\mathbf{0 , 0 3 2}$ \\
SHOC2 & $<50.000 / \mathrm{mm}^{3}$ & 1,7804 & 1,1600 & 2,06008 & \\
& $\geq 50.000 / \mathrm{mm}^{3}$ & 1,2243 & 0,9600 & 1,01210 & 0,28 \\
IGFBP7 & $<50.000 / \mathrm{mm}^{3}$ & 4,0256 & 1,008 & 10,97156 & $\mathbf{0 , 0 5}$ \\
& $\geq 50.000 / \mathrm{mm}^{3}$ & 1,3659 & 0,6020 & 2,41944 & \\
\hline
\end{tabular}

p = nível de significância

Quando se analisou o perfil de expressão gênica em relação à presença do antígeno de superfície CALLA observou-se uma associação significativa entre a hiperexpressão dos genes SHOC2, GATA3 e MAN1A1 e os pacientes com LLA CALLA positivos. Por outro lado, os genes CD44 e MAP3K12 mostraram expressão elevada entre os casos LLA CALLA negativos. Além disso, o gene KCNN1 embora tenha se mostrado hiperexpresso nos pacientes CALLA positivos, em relação aos negativos, pode-se observar que os níveis de expressão foram extremamente baixos. Os valores de p estão descritos na tabela 8 assim como os valores de média e desvio padrão. 
Tabela 8- Expressão relativa dos genes analisados em relação ao marcador CD10 (CALLA).

\begin{tabular}{lccccc}
\hline Gene & CALLA & média & mediana & $\begin{array}{c}\text { desvio } \\
\text { padrão }\end{array}$ & p \\
\hline CD44 & Positivo & 2,0114 & 0,7100 & 4,08353 & \\
& Negativo & 2,2287 & 1,4465 & 2,78433 & $\mathbf{0 , 0 3}$ \\
MAP3K12 & Positivo & 5,3417 & 2,2145 & 13,36578 & \\
& Negativo & 11,1858 & 3,1460 & 27,17098 & $\mathbf{0 , 0 3}$ \\
PCDH9 & Positivo & 10,5139 & 3,5385 & 17,61684 & \\
& Negativo & 9,1806 & 1,0525 & 18,65056 & $\mathbf{0 , 0 8}$ \\
SHOC2 & Positivo & 1,7512 & 1,1435 & 1,95902 & \\
& Negativo & 0,9885 & 0,7520 & 0,83062 & $\mathbf{0 , 0 3}$ \\
GATA3 & Positivo & 2140,7409 & 0,2400 & 22643,7006 & $\mathbf{0 , 0 0 1}$ \\
& Negativo & 17,2465 & 2,9860 & 61,00119 & \\
KCNN1 & Positivo & 0,0030 & 0 & 0,01667 & $\mathbf{0 , 0 0 4}$ \\
& Negativo & 0 & 0 & 0 & \\
MAN1A1 & Positivo & 7,1527 & 0,8725 & 46,96374 & $\mathbf{0 , 0 5}$ \\
& Negativo & 1,5588 & 0,5215 & 3,20235 & \\
\hline
\end{tabular}

Em relação à avaliação da medula óssea no $28^{\circ}$ dia da indução, apenas os genes MAP3K12 e TRIM24 apresentaram associação significativa entre o nível de expressão aumentado e a presença de medula M1 (Tabela 9).

Tabela 9- - Expressão relativa dos genes analisados em relação à Medula óssea no $28^{\circ}$ dia.

\begin{tabular}{cccccc}
\hline Gene & MO 28 & média & mediana & $\begin{array}{c}\text { Desvio } \\
\text { padrão }\end{array}$ & p \\
\hline MAP3K12 & M1 & 6,8708 & 2,6700 & 17,53504 & \\
& M2/M3 & 1,5228 & 1,3327 & 1,18876 & $\mathbf{0 , 0 3 2}$ \\
TRIM24 & M1 & 3,3534 & 1,6640 & 8,46511 & \\
& M2/M3 & 1,6789 & 0,9505 & 2,71624 & $\mathbf{0 , 0 4}$ \\
\hline
\end{tabular}

$\mathrm{p}=$ nível de significância 
Na análise da expressão gênica de acordo com a resposta ao tratamento foram analisados pacientes considerados bons respondedores versus maus respondedores, sendo encontrada uma única associação significativa entre a hiperexpressão do gene TCFL5 e o grupo de pacientes considerados bons respondedores $(p=0,031)$. Todos os demais genes analisados não apresentaram associação estatisticamente significativa (dados não mostrados).

Quanto à associação entre a expressão gênica diferencial e a presença da translocação t(12;21) (ETV6-RUNX1 ou TEL/AML1) observamos uma correlação significativa entre os genes TCFL5 e TRIM24, que se apresentaram hiperexpressos, e a ausência da translocação. A análise mostrou ainda uma associação positiva entre a presença da mesma e o gene KCNN1 (embora com níveis de expressão extremamente baixos), além da uma tendência de correlação com o gene $C D 69$ (p=0,058). Os dados referentes a essa análise estão destacados na tabela 10.

Para as demais translocações, foram feitas análises considerando-se a ausência ou a presença isolada da $t(12 ; 21)$ versus as translocações $t(9 ; 22)$ e $t(4 ; 11)$ agrupadas, entretanto não foi observada correlação significativa. 
Tabela 10- Expressão relativa dos genes analisados em relação à presença de translocações

\begin{tabular}{lccccc}
\hline \multicolumn{1}{c}{ Gene } & TEL/AML1 & média & mediana & $\begin{array}{c}\text { desvio } \\
\text { padrão }\end{array}$ & p \\
\hline CD69 & Positivo & 9,2572 & 4,1810 & 13,48505 & \\
& Negativo & 3,5593 & 1,5550 & 4,97366 & 0,058 \\
TCFL5 & Positivo & 11,5714 & 2,8165 & 25,35271 & \\
& Negativo & 104,1087 & 5,2510 & 236,50491 & $\mathbf{0 , 0 1}$ \\
KCNN1 & Positivo & 0,0035 & 0 & 0,01798 & \\
& Negativo & 0 & 0 & 0,000001 & $\mathbf{0 , 0 0 5}$ \\
& Positivo & 2,1610 & 1,4175 & 3,85508 & $\mathbf{0 , 0 3}$ \\
TRIM24 & Negativo & 18,7568 & 1,1740 & 32,56989 & \\
\hline $\mathrm{p}=$ nível de significância & & & &
\end{tabular}

Em relação à presença de doença residual mínima (DRM), avaliada no $28^{\circ}$ dia após o início do tratamento, observamos uma associação significativa entre a hiperexpressão dos genes CD69 ( $p=0,037), \operatorname{PCDH9}(p=0,034), \operatorname{KCNN1}(p=0,001)$, TCFL5 $(0,005)$ e TRIM24 $(\mathrm{p}=0,031)$ e a presença de DRM (Figura 3).

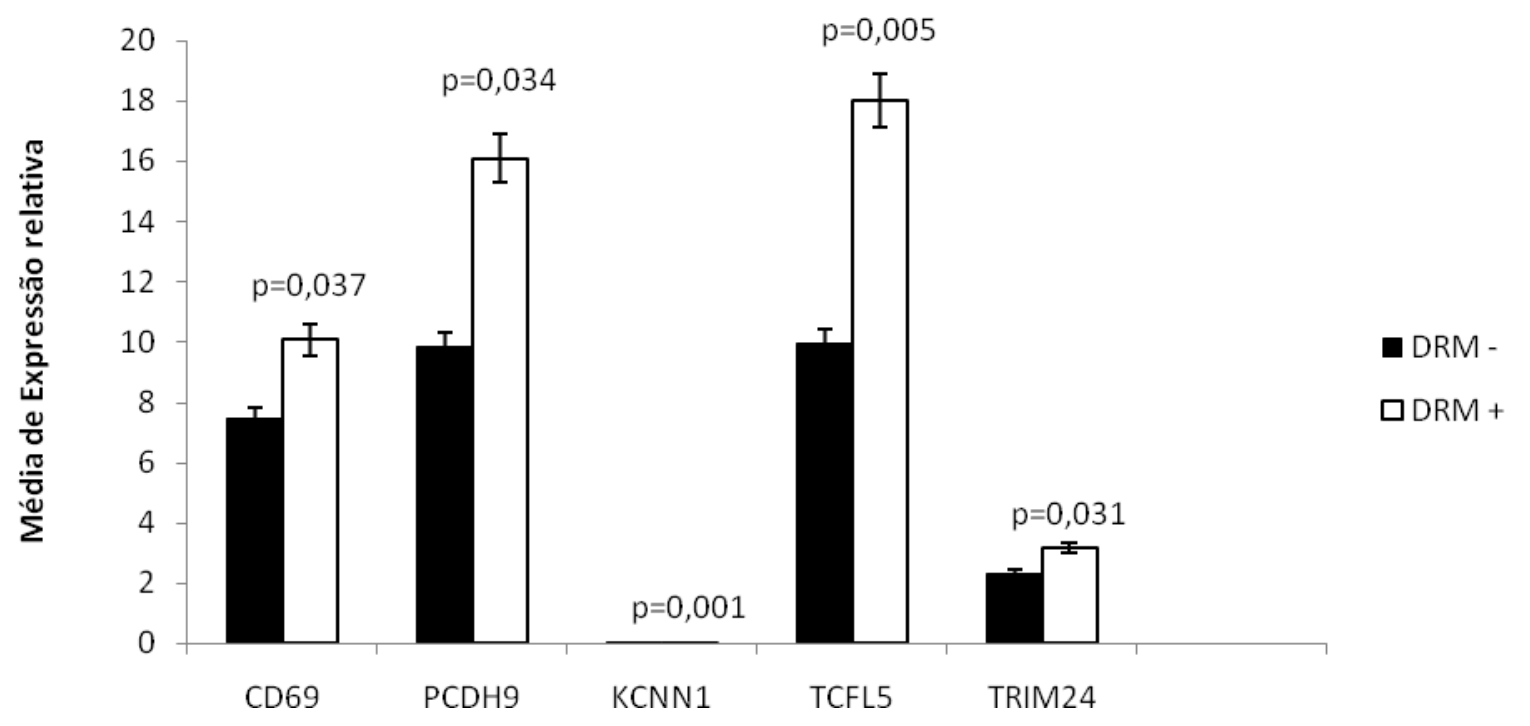

Figura 3. Perfil de expressão gênica dos genes TRIM24, TCFL5, KCNN1, PCDH9 e CD69 em relação à presença de doença residual mínima no $28^{\circ}$ dia após a indução. 
Comparando os subtipos de LLA (LLA B versus LLA T) observou-se valores de expressão significativamente maiores entre o grupo de leucemias $\mathrm{B}$, em relação às leucemias $\mathrm{T}$, para os genes MAP3K12, PCDH9, GATA3 e KCNN1. Além disso, observamos ainda uma tendência de associação dos genes IGFBP7, GPR56, SHOC2, CDK2AP1 e CD44, no entanto, os valores de $\mathrm{p}$ não tenham atingido significância estatística. Todos os dados e os respectivos valores de p estão representados na Tabela 11.

Tabela 11- Expressão relativa dos genes analisados em relação ao imunofenótipo.

\begin{tabular}{|c|c|c|c|c|c|}
\hline Gene & Imunofenótipo & média & mediana & $\begin{array}{l}\text { desvio } \\
\text { padrão }\end{array}$ & $\mathrm{p}$ \\
\hline \multirow[t]{2}{*}{ CD44 } & LLA B & 2.0560 & 0,770 & 4.03225 & \multirow[b]{2}{*}{0.073} \\
\hline & LLA T & 2.2290 & 1,396 & 3.02212 & \\
\hline \multirow[t]{2}{*}{ МАРЗК12 } & LLA B & 5.2487 & 2,190 & 13.09526 & \multirow[b]{2}{*}{0.006} \\
\hline & LLA T & 14.9011 & 4,201 & 32.19416 & \\
\hline \multirow[t]{2}{*}{ PCDH9 } & LLA B & 10.7233 & 4,080 & 17.43413 & \multirow[b]{2}{*}{0.03} \\
\hline & LLA T & 8.8568 & 0,656 & 21.13791 & \\
\hline \multirow{2}{*}{ SHOC2 } & LLA B & 1.6603 & 1,120 & 1.81881 & \multirow[b]{2}{*}{0.08} \\
\hline & LLA T & 0.9761 & 0,692 & 0.80538 & \\
\hline \multirow{2}{*}{ GATA3 } & LLA B & 2049.3041 & 0,230 & 22154.57834 & \multirow[b]{2}{*}{$<0.0001$} \\
\hline & LLA T & 24.5198 & 7,001 & 72.73132 & \\
\hline \multirow{2}{*}{ KCNN1 } & LLA B & 0.0029 & 0 & 0.01632 & \multirow[b]{2}{*}{0.015} \\
\hline & LLA T & 0.0000 & 0 & 0.00002 & \\
\hline \multirow{2}{*}{ IGFBP7 } & LLA B & 3.5823 & 1,750 & 9.98979 & \multirow[b]{2}{*}{0.062} \\
\hline & LLA T & 1.0893 & 0,353 & 2.15730 & \\
\hline \multirow[t]{2}{*}{$C D K 2 A P 1$} & LLA B & 3.7976 & 2,640 & 3.65717 & \multirow[b]{2}{*}{0.08} \\
\hline & LLA T & & 5,169 & & \\
\hline \multirow[t]{2}{*}{ GPR56 } & LLA B & 44,328 & 1,80 & 418,709 & \multirow{2}{*}{0.056} \\
\hline & LLA T & 28,775 & 4,80 & 103,96 & \\
\hline
\end{tabular}


Para as demais variáveis clínicas como idade, grupo de risco, glóbulos brancos no sétimo dia da indução, medula óssea no décimo quarto dia da indução, resposta à indução, presença de translocações, ocorrência de evento desfavorável e acometimento do sistema nervoso central, não foi observada correlação estatística através do teste não-paramétrico de Mann-Whitney para os genes analisados. Os dados referentes a essas análises foram resumidos e descritos na Tabela 12.

Tabela 12. Associação entre as variáveis clínicas e a expressão dos demais genes analisados (valores de p).

\begin{tabular}{lcccccccc}
\hline & Evento & GBd7 & Idade & MO14 & Resposta & Risco & SNC & $\begin{array}{c}\text { Translo - } \\
\text { cação }\end{array}$ \\
\hline BLVRB & 0,81 & 0,597 & 0,725 & 0,349 & 0,726 & 0,381 & 0,251 & 0,593 \\
CD44 & 0,511 & 0,759 & 0,866 & 0,585 & 0,925 & 0,449 & 0,734 & 0,704 \\
CD69 & 0,933 & 0,911 & 0,214 & 0,539 & 0,771 & 0,826 & 0,076 & 0,254 \\
CDK2AP1 & 0,967 & 0,98 & 0,567 & 0,379 & 0,642 & 0,973 & 0,556 & 0,955 \\
EGR1 & 0,404 & 0,59 & 0,14 & 0,817 & 0,937 & 0,29 & 0,270 & 0,933 \\
F8A & 0,971 & 0,693 & 0,78 & 0,31 & 0,813 & 0,481 & 0,817 & 0,278 \\
KCNN4 & 0,971 & 0,916 & 0,488 & 0,743 & 0,832 & 0,467 & 0,101 & 0,456 \\
MAP3K12 & 0,912 & 0,467 & 0,808 & 0,134 & 0,126 & 0,607 & 0,651 & 0,888 \\
PCDH9 & 0,846 & 0,888 & 0,599 & 0,996 & 0,852 & 0,368 & 0,70 & 0,278 \\
SHOCK2 & 0,257 & 0,49 & 0,877 & 0,122 & 0,178 & 0,565 & 0,218 & 0,746 \\
GATA3 & 0,528 & 0,924 & 0,792 & 0,284 & 0,366 & 0,656 & 0,811 & 0,644 \\
GPR56 & 0,063 & 0,40 & 0,437 & 0,188 & 0,339 & 0,417 & 0,069 & 0,105 \\
IGBP7 & 0,377 & 0,667 & 0,757 & 0,957 & 0,777 & 0,288 & 0,815 & 0,434 \\
KCNN1 & 0,352 & 0,371 & 0,440 & 0,677 & 0,698 & 0,515 & 0,435 & 0,185 \\
MAN1A1 & 0,572 & 0,180 & 0,014 & 0,254 & 0,325 & 0,151 & 0,491 & 0,728 \\
RPLP2 & 0,918 & 0,394 & 0,248 & 0,722 & 0,628 & 0,232 & 0,380 & 0,306 \\
CLEC11A & 0,579 & 0,649 & 0,950 & 0,471 & 0,626 & 0,808 & 0,216 & 0,091 \\
TCFL5 & 0,658 & 0,240 & 0,166 & 0,144 & 0,871 & 0,772 & 0,498 & 0,541 \\
TRIM24 & 0,743 & 0,758 & 0,31 & 0,468 & 0,702 & 0,776 & 0,737 & 0,744 \\
\hline
\end{tabular}




\subsection{ANÁLISE DE SOBREVIDA LIVRE DE EVENTOS - Pacientes portadores}

\section{de LLA submetidos ao protocolo de tratamento do GBTLI}

Para a análise da sobrevida livre de eventos (SLE) foram utilizados os dados de expressão de cada gene estudado de acordo com os valores abaixo da mediana (hipoexpressos) e acima da mediana (hiperexpressos) de cada paciente. As curvas de sobrevida foram feitas para todos os genes estudados, pelo teste log hank e as curvas de Kaplan Meiyer estão representadas nas figuras 4 a 13.

A SLE em 5 anos de todos os pacientes analisados em conjunto foi de $76 \%$ (RB-82\% vs AR-66\%). Na análise de SLE em 5 anos dos genes analisados, observamos uma associação significativa entre a sobrevida dos pacientes e a hiperexpressão dos genes SHOC2 ( $\mathrm{p}=0,032)$ e GPR56 $(\mathrm{p}=0,05)$.

Todos os demais genes analisados não apresentaram associação significativa entre a sobrevida e os níveis de expressão.
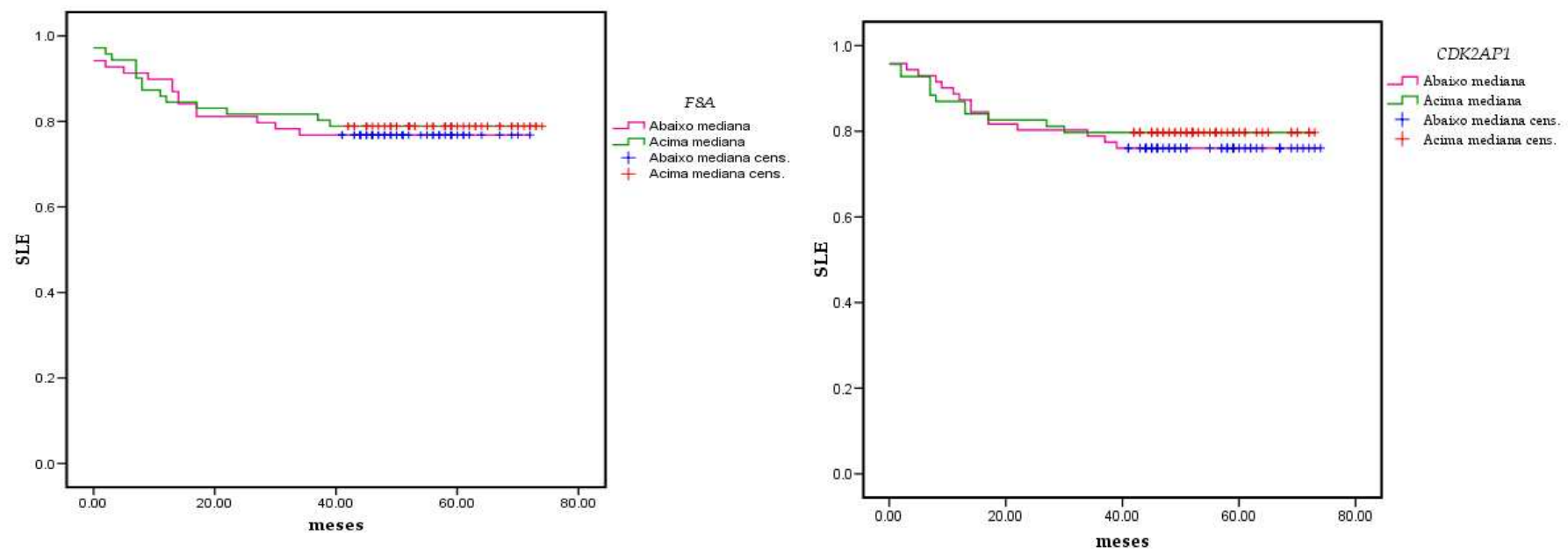

Figura 4- Sobrevida livre de eventos para os grupos de pacientes com expressão do gene $F 8 A$ $(\mathrm{p}=0,781)$ e $C D K 2 A P 1(0,062)$. 

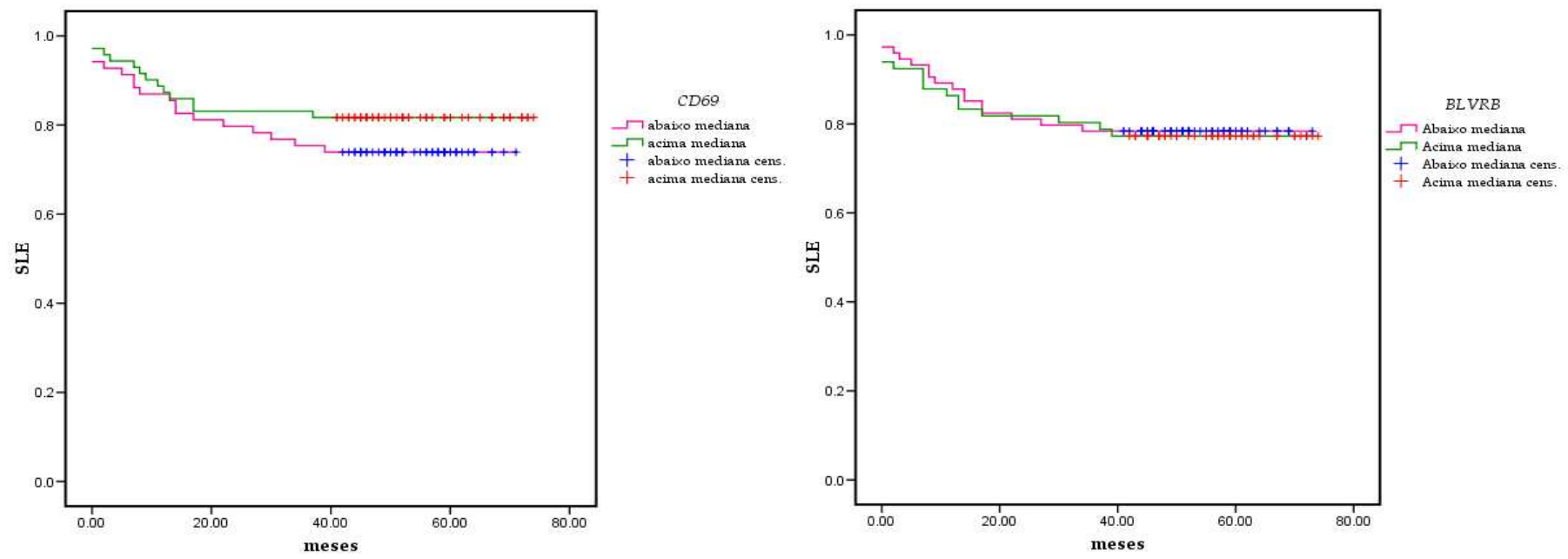

Figura 5- Sobrevida livre de eventos para os grupos de pacientes com expressão do gene $C D 69(\mathrm{p}=0,285)$ e $B L V R B(\mathrm{p}=0,854)$
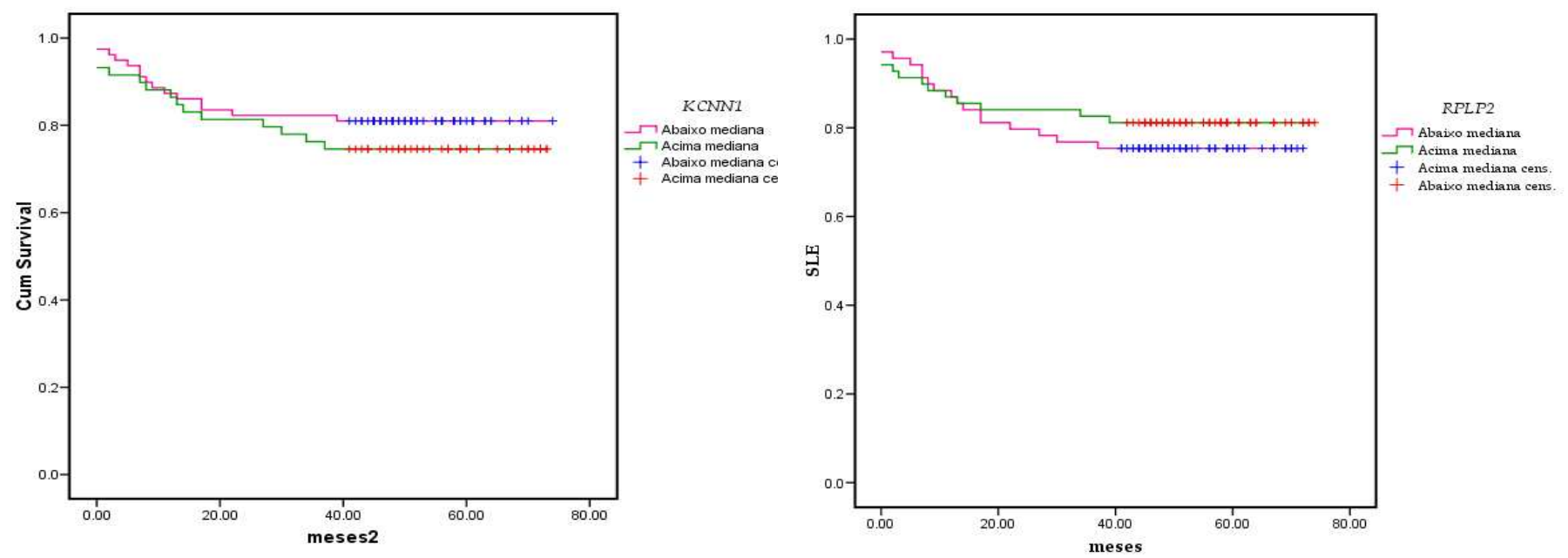

Figura 6- Sobrevida livre de eventos para os grupos de pacientes com expressão do gene KCNN1 $(\mathrm{p}=0,662)$ e RPLP2 $(\mathrm{p}=0,453)$. 

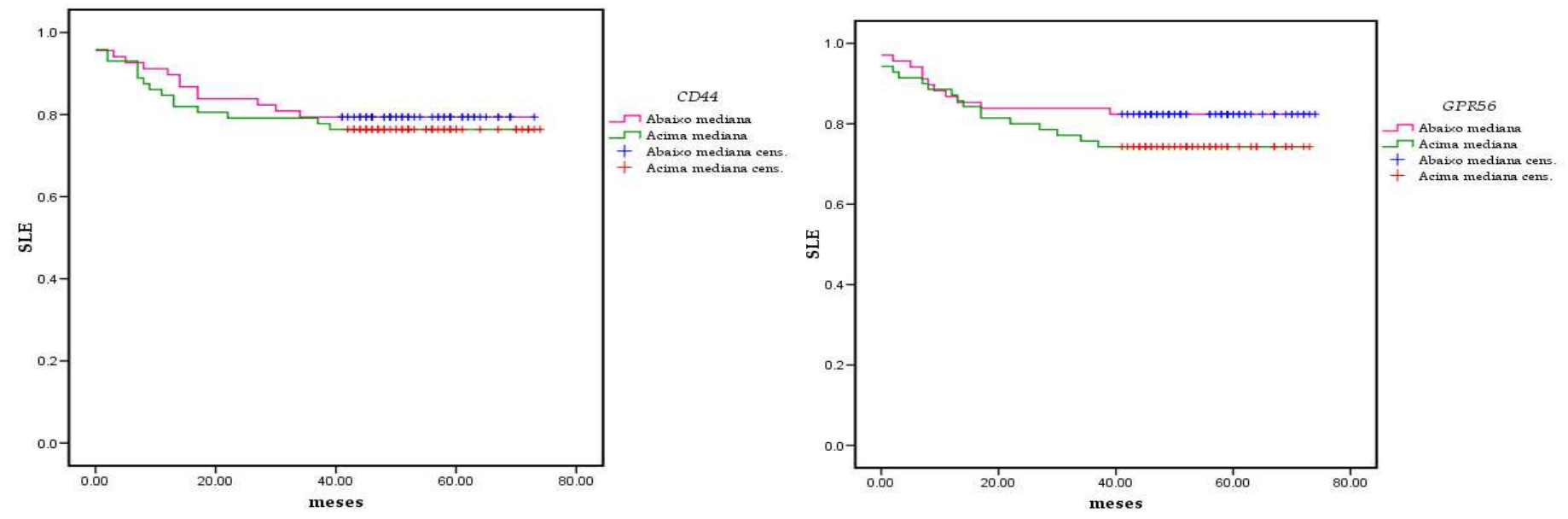

Figura 7: Sobrevida livre de eventos para os grupos de pacientes com expressão do gene CD44 ( $\mathrm{p}=0,692)$ e GPR56 $(\mathrm{p}=0,052)$.
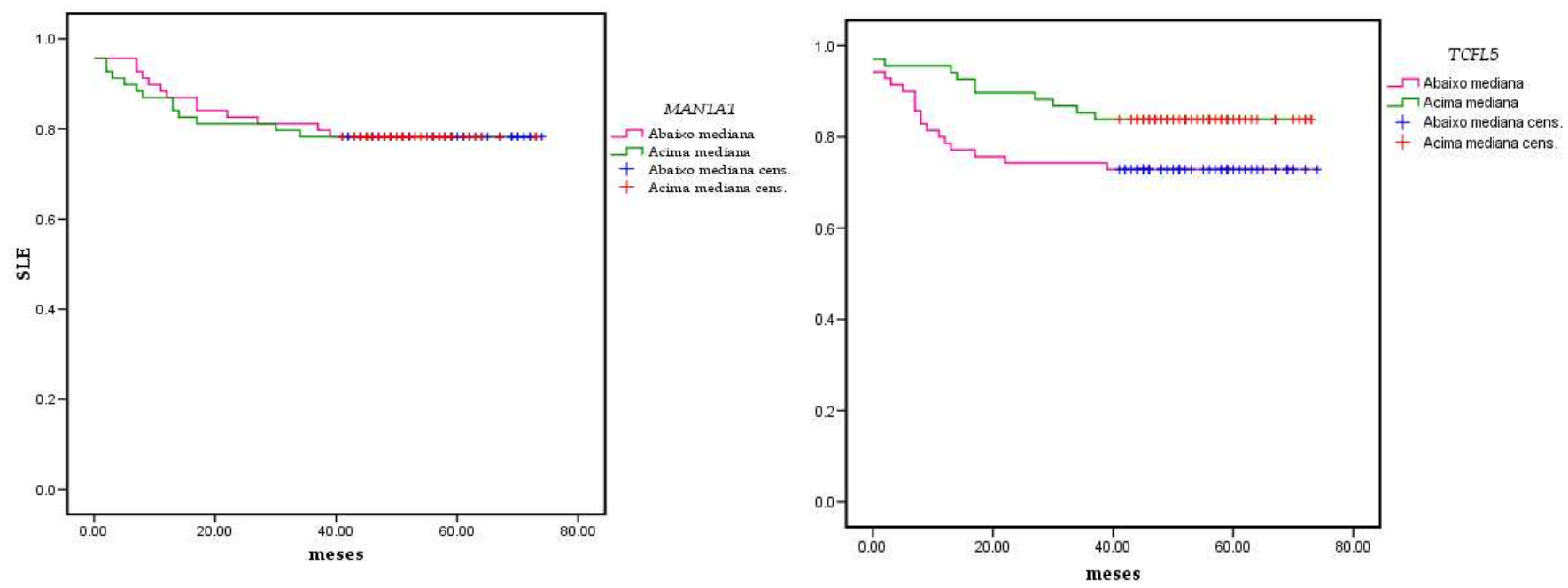

Figura 8- Sobrevida livre de eventos para os grupos de pacientes com expressão do gene MAN1A1 $(\mathrm{p}=0943)$ e TCFL52 $(\mathrm{p}=0,094)$. 

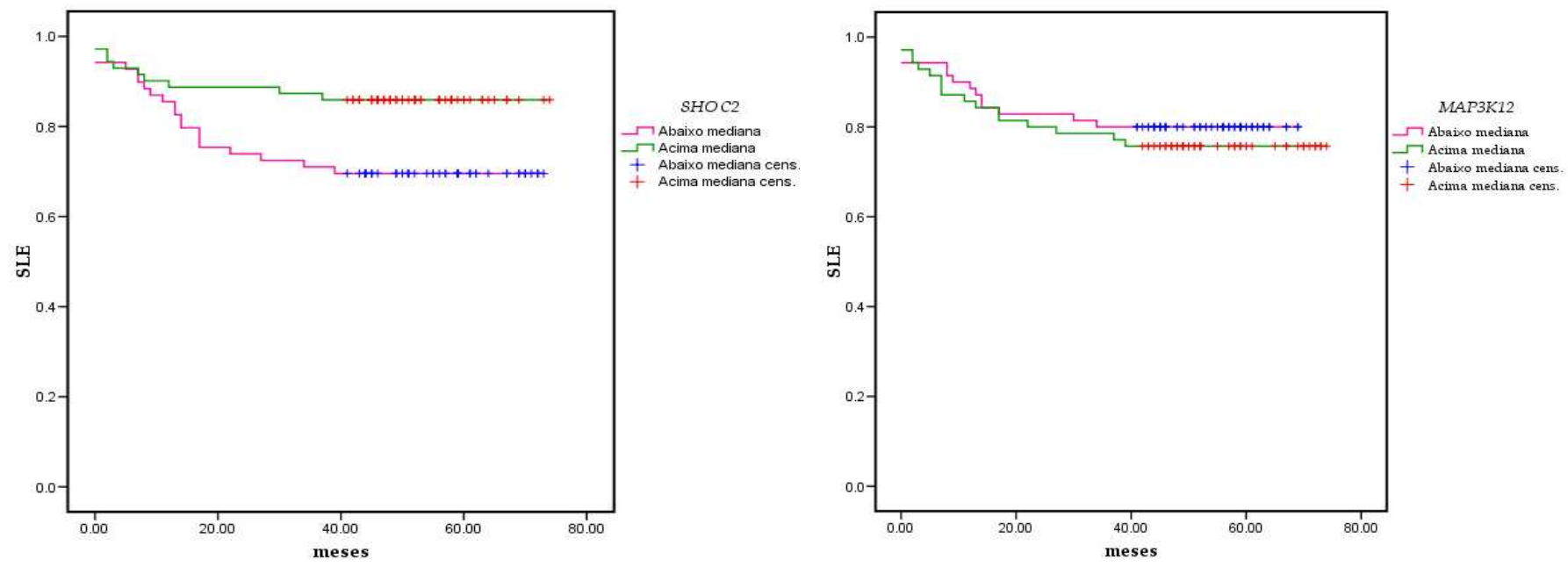

Figura 9- Sobrevida livre de eventos para os grupos de pacientes com expressão do gene TC SHOC2 $(\mathrm{p}=0,023)$ e MAP3K12 $(\mathrm{p}=0,547)$.
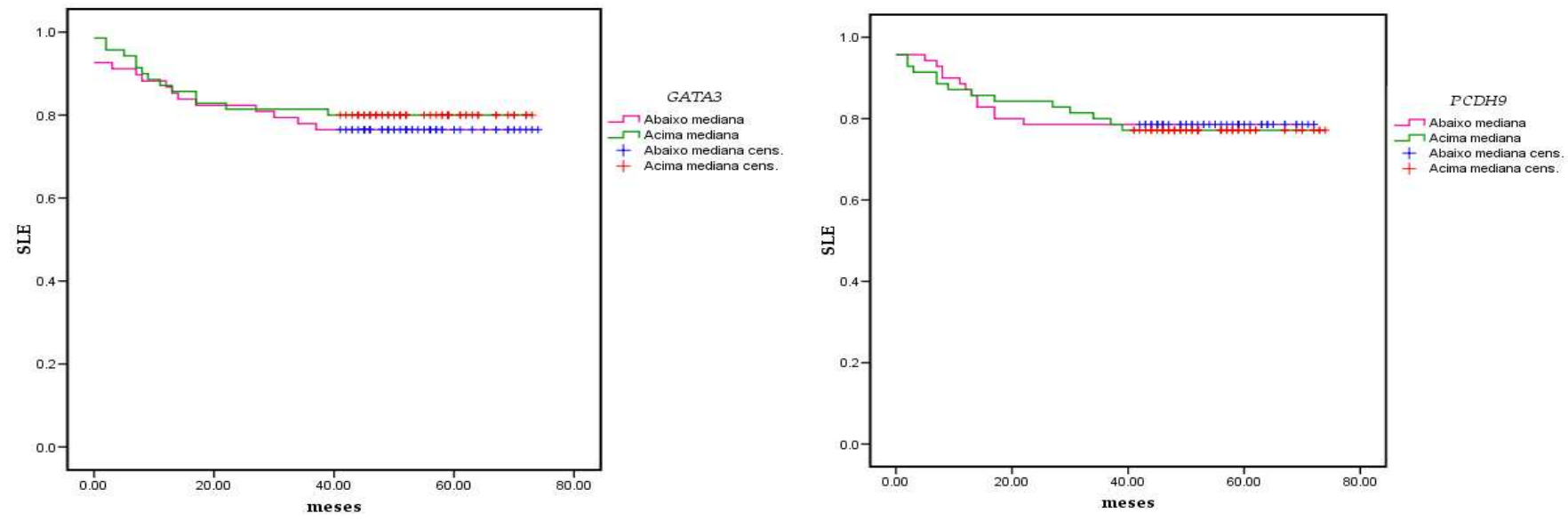

Figura 10- Sobrevida livre de eventos para os grupos de pacientes com expressão do gene GATA3 $(\mathrm{p}=0,617)$ e PCDH9 $(\mathrm{p}=0,857)$ 

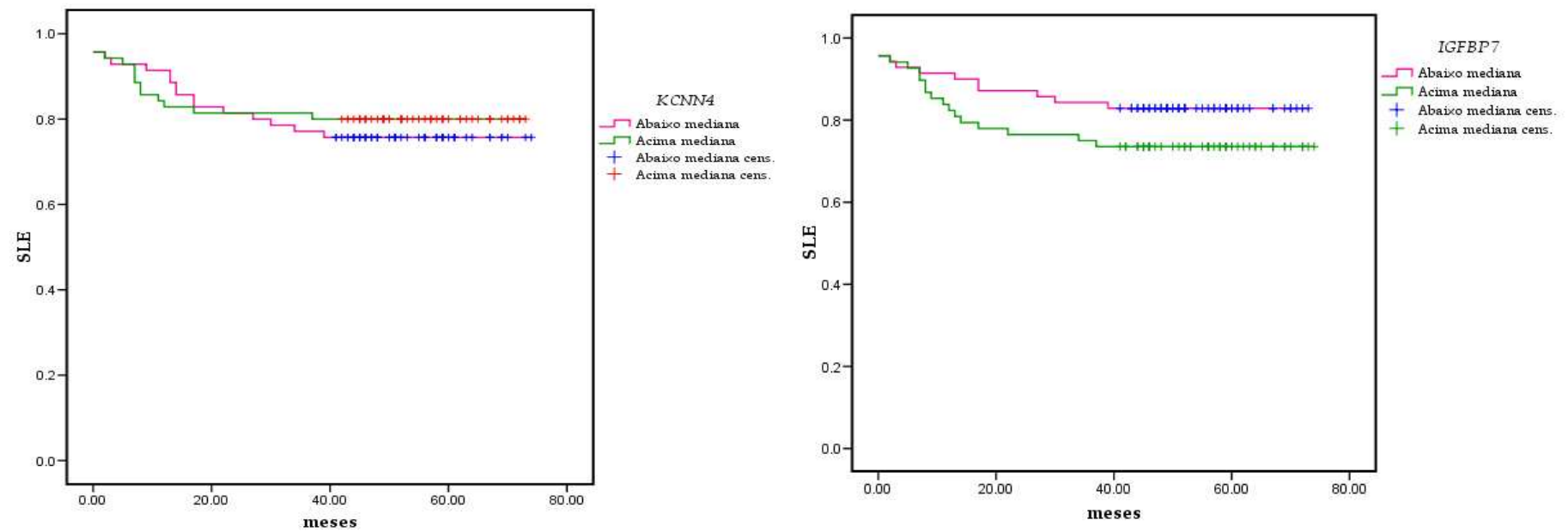

Figura 11- Sobrevida livre de eventos para os grupos de pacientes com expressão do gene KCNN4 $(\mathrm{p}=0,626)$ e IGFBP7 $(\mathrm{p}=0,182)$
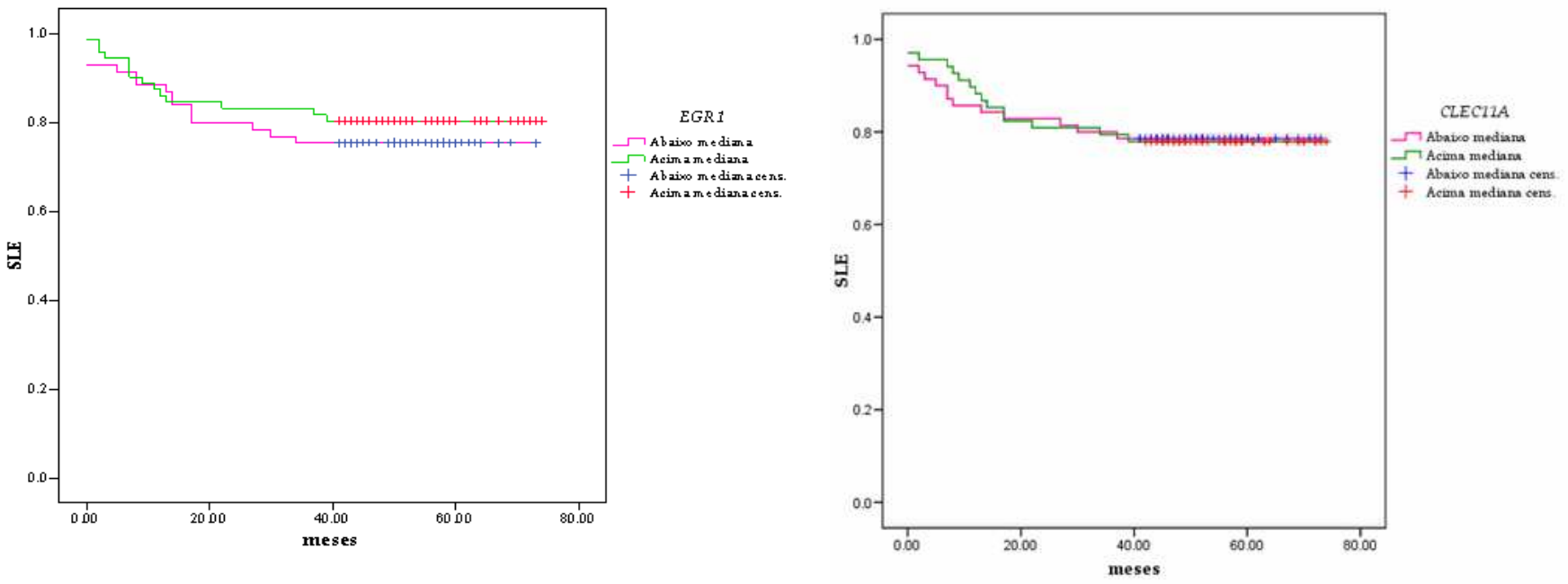

Figura 12- Sobrevida livre de eventos para os grupos de pacientes com expressão do gene EGR1 $(\mathrm{p}=0,500)$ e CLEC11A ( $\mathrm{p}=0,991)$ 


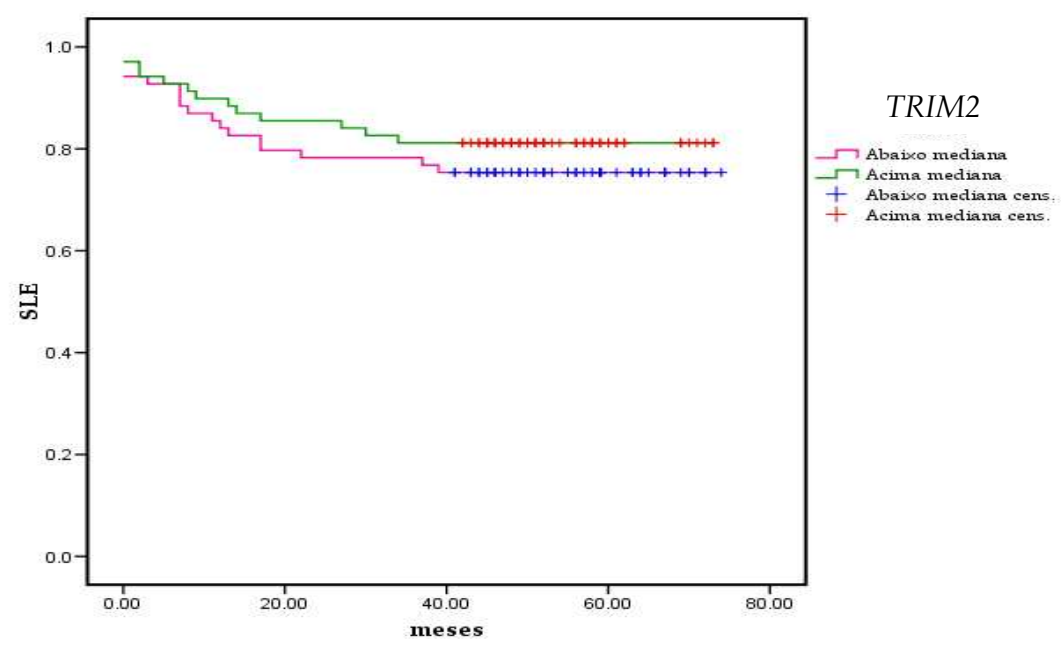

Figura 13- Sobrevida livre de eventos para os grupos de pacientes com expressão do gene TRIM24 $(\mathrm{p}=0,407)$

\subsection{ANÁLISE DE CORRELAÇÃO ENTRE OS VALORES DE EXPRESSÃO}

Para verificar se os genes estudados no presente trabalho apresentavam correlação entre si, realizou-se a análise da correlação entre os valores de expressão dos genes através do coeficiente de correlação de Spearman. Os genes foram agrupados com relação à resistência e/ou sensibilidades aos quimioterápicos prednisona, asparaginase, daunorrubicina e vincristina.

Entre o grupo de genes associados à prednisona observou-se uma forte correlação entre os genes $B L V R B, C D K 2 A P 1$ e $F 8 A(\mathrm{p}<0,02)$. Para os genes associados à vincristina, verificou-se uma correlação significativa entre os genes CD44 e RPLP2, KCNN1, TCFL5 e RPLP2 e ainda entre os genes TCFL5, TRIM24 e RPLP2 ( $<<0,05)$.

Os valores verificados para essa correlação encontram-se detalhados nas tabelas 13 e 14 . 
Tabela 13: Coeficiente de relação de Spearman observado entre os genes associados à prednisona

\begin{tabular}{|c|c|c|c|c|c|c|}
\hline & & & $B L V R B$ & CD69 & $C D K 2 A P 1$ & $F 8 A$ \\
\hline \multirow[t]{8}{*}{ Spearman's rho } & \multirow[t]{2}{*}{$B L V R B$} & Coeficiente de relação & 1,000 & 0,045 & 0,200 & 0,405 \\
\hline & & Sig. (2-tailed) & & 0,599 & $0,018^{*}$ & $0,000^{*}$ \\
\hline & \multirow[t]{2}{*}{ CD69 } & Coeficiente de relação & 0,045 & \multirow[t]{2}{*}{1,000} & 0,141 & 0,312 \\
\hline & & Sig. (2-tailed) & 0,599 & & 0,097 & $0,000^{*}$ \\
\hline & \multirow[t]{2}{*}{ CDK2AP1 } & Coeficiente de relação & 0,200 & 0,141 & \multirow[t]{2}{*}{1,000} & .075 \\
\hline & & Sig. (2-tailed) & $0,018^{*}$ & 0,097 & & 0,376 \\
\hline & \multirow[t]{2}{*}{$F 8 A$} & Coeficiente de relação & 0,405 & 0,312 & 0,075 & \multirow[t]{2}{*}{1,000} \\
\hline & & Sig. (2-tailed) & $0,000^{*}$ & $0,000^{*}$ & 0,376 & \\
\hline
\end{tabular}

*Estatisticamente significativo

Tabela 14: Coeficiente de relação de Spearman observado entre os genes associados à vincristina

\begin{tabular}{|c|c|c|c|c|c|c|c|}
\hline & & & CD44 & KCNN1 & TCFL5 & TRIM24 & RPLP2 \\
\hline \multirow{10}{*}{ Spearman's rho } & \multirow[t]{2}{*}{$\overline{C D 44}$} & Coeficiente de relação & 10,000 & $-0,159$ & $-0,082$ & $-0,036$ & 0,219 \\
\hline & & Sig. (2-tailed) & & 0,063 & 0,342 & 0,678 & 0,010 \\
\hline & \multirow[t]{2}{*}{ KCNN1 } & Coeficiente de relação & $-0,159$ & 10,000 & 0,312 & 0,141 & $-0,174$ \\
\hline & & Sig. (2-tailed) & 0,063 & & 0,000 & 0,099 & 0,041 \\
\hline & \multirow[t]{2}{*}{ TCFL5 } & Coeficiente de relação & $-0,082$ & 0,312 & 10,000 & 0,494 & 0,442 \\
\hline & & Sig. (2-tailed) & 0,342 & 0,000 & & 0,000 & 0,000 \\
\hline & \multirow[t]{2}{*}{ TRIM24 } & Coeficiente de relação & $-0,036$ & 0,141 & 0,494 & 10,000 & 0,195 \\
\hline & & Sig. (2-tailed) & 0,678 & 0,099 & 0,000 & & 0,022 \\
\hline & \multirow[t]{2}{*}{$R P L P 2$} & Coeficiente de relação & 0,219 & $-0,174$ & 0,442 & 0,195 & 10,000 \\
\hline & & Sig. (2-tailed) & 0,010 & 0,041 & 0,000 & 0,022 & \\
\hline
\end{tabular}

* Estatisticamente significativo

Com relação aos genes associados à resistência e ou sensibilidade à daunorrubicina, verificou-se uma correlação positiva entre os genes MAP3K12, EGR1 e KCNN4 $(\mathrm{p}<0,02)$. O gene SHOC2 também esteve significativamente correlacionado 
com os genes PCDH9 e EGR1 $(\mathrm{p}<0,05)$ além de apresentar uma tendência à correlação com o gene KCNN4 $(\mathrm{p}=0,09)$. Todos os dados estão representados na tabela 15.

Tabela 15: Coeficiente de relação de Spearman observado entre os genes associados à daunorrubicina.

\begin{tabular}{|c|c|c|c|c|c|c|c|}
\hline & & & МАРЗК12 & SHOC2 & PCDH9 & EGR1 & KCNN4 \\
\hline \multirow[t]{10}{*}{ Spearman's rho } & MAР3К12 & Coeficiente de relação & 1,000 & 0,046 & 0,049 & 0,406 & 0,201 \\
\hline & & Sig. (2-tailed) & & 0,590 & 0,566 & $0,000^{*}$ & $0,017^{*}$ \\
\hline & SHOC2 & Coeficiente de relação & 0,046 & 1,000 & 0,176 & 0,207 & 0,144 \\
\hline & & Sig. (2-tailed) & 0,590 & & $0,038^{*}$ & $0,014^{*}$ & 0,090 \\
\hline & PCDH9 & Coeficiente de relação & 0,049 & 0,176 & 1,000 & 0,135 & 0,033 \\
\hline & & Sig. (2-tailed) & 0,566 & 0,038 & & 0,112 & 0,702 \\
\hline & EGR1 & Coeficiente de relação & 0,406 & 0,207 & 0,135 & 1,000 & 0,282 \\
\hline & & Sig. (2-tailed) & $0,000^{*}$ & $0,014^{*}$ & 0,112 & & $0,001^{*}$ \\
\hline & KCNN4 & Coeficiente de relação & 0,201 & 0,144 & 0,033 & 0,282 & 1,000 \\
\hline & & Sig. (2-tailed) & $0,017^{*}$ & 0,090 & 0,702 & $0,001^{*}$ & \\
\hline
\end{tabular}

${ }^{*}$ Estatisticamente significativo

Para os genes pertencentes ao grupo de resistência relacionado ao quimioterápico asparaginase, o teste de Spearman mostrou uma correlação estatisticamente significativa entre os genes GATA3 e IGFBP7 $(\mathrm{p}=0,008)$. Outra correlação positiva, destacada na tabela 16, foi observada entre os genes GPR56 e MAN1A1 $(\mathrm{p}<0,001)$ e entre os genes IGFBP7 e CLEC11A $(\mathrm{p}=0,002)$. 
Tabela 16: Coeficiente de relação de Spearman observado entre os genes associados à asparaginase

\begin{tabular}{|c|c|c|c|c|c|c|c|}
\hline & & & GATA3 & GPR56 & IGFBP7 & MAN1A1 & CLEC11A \\
\hline \multirow[t]{10}{*}{ Spearman's rho } & \multirow[t]{2}{*}{ GATA3 } & Coeficiente de relação & 1,000 & $-0,098$ & $-0,226$ & $-0,090$ & 0,062 \\
\hline & & Sig. (2-tailed) & & 0,251 & $0,008^{*}$ & 0,293 & 0,469 \\
\hline & \multirow[t]{2}{*}{ GPR56 } & Coeficiente de relação & $-0,098$ & \multirow[t]{2}{*}{1,000} & $-0,026$ & 0,486 & 0,152 \\
\hline & & Sig. (2-tailed) & 0,251 & & 0,760 & $0,000^{*}$ & 0,076 \\
\hline & \multirow[t]{2}{*}{ IGFBP7 } & Coeficiente de relação & $-0,226$ & $-0,026$ & \multirow[t]{2}{*}{1,000} & $-0,108$ & 0,264 \\
\hline & & Sig. (2-tailed) & $0,008^{*}$ & 0,760 & & 0,206 & $0,002^{*}$ \\
\hline & \multirow[t]{2}{*}{ MAN1A } & Coeficiente de relação & $-0,090$ & 0,486 & $-0,108$ & \multirow[t]{2}{*}{1,000} & 0,011 \\
\hline & & Sig. (2-tailed) & 0,293 & $0,000^{*}$ & 0,206 & & 0,894 \\
\hline & \multirow[t]{2}{*}{ CLEC11 } & Coeficiente de relação & 0,062 & 0,152 & 0,264 & 0,011 & \multirow[t]{2}{*}{1,000} \\
\hline & & Sig. (2-tailed) & 0,469 & 0,076 & $0,002^{*}$ & 0,894 & \\
\hline
\end{tabular}

*Estatisticamente significativo

\subsection{ANÁLISE DE EXPRESSÃO GÊNICA DOS GENES SHOC2 E GPR56 -}

\section{Pacientes portadores de LLA submetidos ao protocolo de tratamento BFM-2000}

De acordo com as análises realizadas anteriormente observamos que dentre o painel de genes avaliados os genes SHOC2 e GPR56 mostraram-se significativamente associados a uma elevada SLE, destacando-se entre os demais como possíveis marcadores de bom prognóstico (associado à resposta ao tratamento). Dessa forma, com o intuito de avaliar o perfil de expressão dos mesmos em pacientes portadores de LLA submetidos a outro protocolo de tratamento, foram analisados 60 pacientes pertencentes ao grupo AIEOP e submetidos ao protocolo do BFM-2000.

Os pacientes foram divididos inicialmente de acordo com o risco de recaída, avaliado no $14^{\circ}$ dia da indução e que determina dois grupos: risco básico e risco alto risco, sendo que ambos apresentaram boa resposta à prednisona na fase de 
indução. Quando se avaliou o perfil de expressão dos dois grupos observou-se um padrão de expressão significativamente superior do gene SHOC2 entre os pacientes de risco básico quando comparados aos pacientes classificados como de alto risco $(\mathrm{p}=0,0005)$. Por outro lado, a análise de expressão para o gene GPR56 não apresentou diferença estatisticamente significativa entre os dois grupos analisados $(p=0,136)$. Os dados referentes a essas análises estão demonstrados nas figuras 14 e 15.

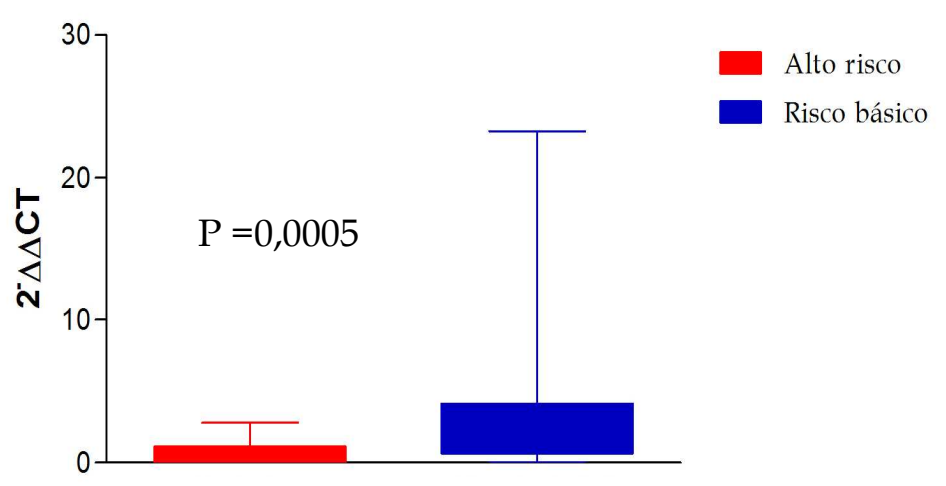

SHOC2

Figura 14. Perfil de expressão do gene $S H O C 2$ entre os grupos de pacientes de alto e baixo risco $\equiv$

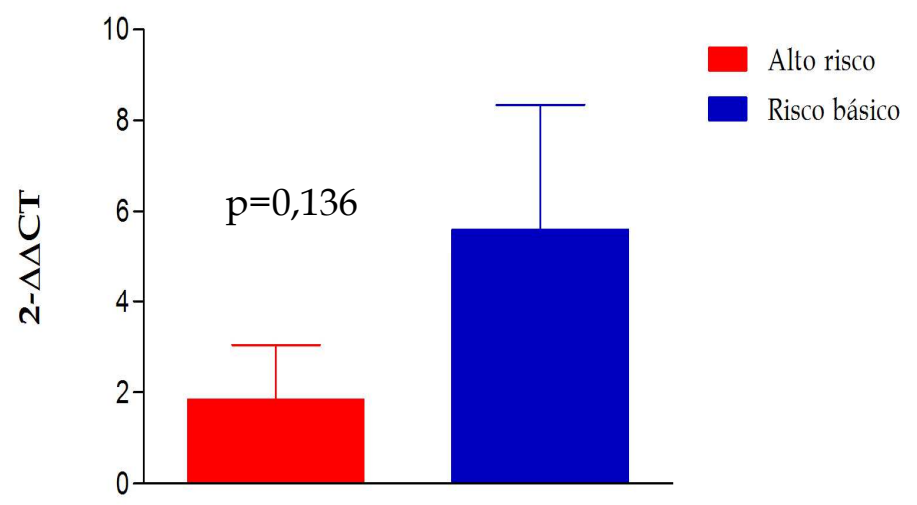

GPR56

Figura 15. Perfil de expressão do gene GPR56 entre os grupos de pacientes de alto e baixo $\equiv$ o. 
Posteriormente, foram incluídos na análise os pacientes inicialmente classificados como maus respondedores à prednisona na fase de indução. O perfil de expressão gênica dos genes SHOC2 e GPR56 foi então avaliado em três grupos de pacientes: bons respondedores e de risco básico, bons respondedores e de alto risco de recidiva e finalmente os maus respondedores à prednisona.

O perfil de expressão do gene SHOC2 observado inicialmente se manteve quando reagrupamos os pacientes e incluímos o grupo de maus respondedores e, além disso, observou-se que a média de expressão tende a diminuir de acordo com um pior fator prognóstico. Quando comparamos o grupo de risco básico e o grupo de pacientes que apresentaram má resposta à prednisona, observamos índices de expressão significativamente diminuídos $(p=0,009)$. Ao analisar o perfil de expressão entre os grupos de alto risco e de maus respondedores, observou-se uma tendência de associação entre a elevada média de expressão do SHOC2 e o grupo de alto risco, entretanto a diferença obtida não foi estatisticamente significativa $(p=0,06)$.

Na análise do gene GPR56 também se pode observar uma queda na expressão relacionada com um pior fator prognóstico porém, não foram observadas diferenças estatisticamente significativas entre os grupos analisados (Figuras 16 e 17). 


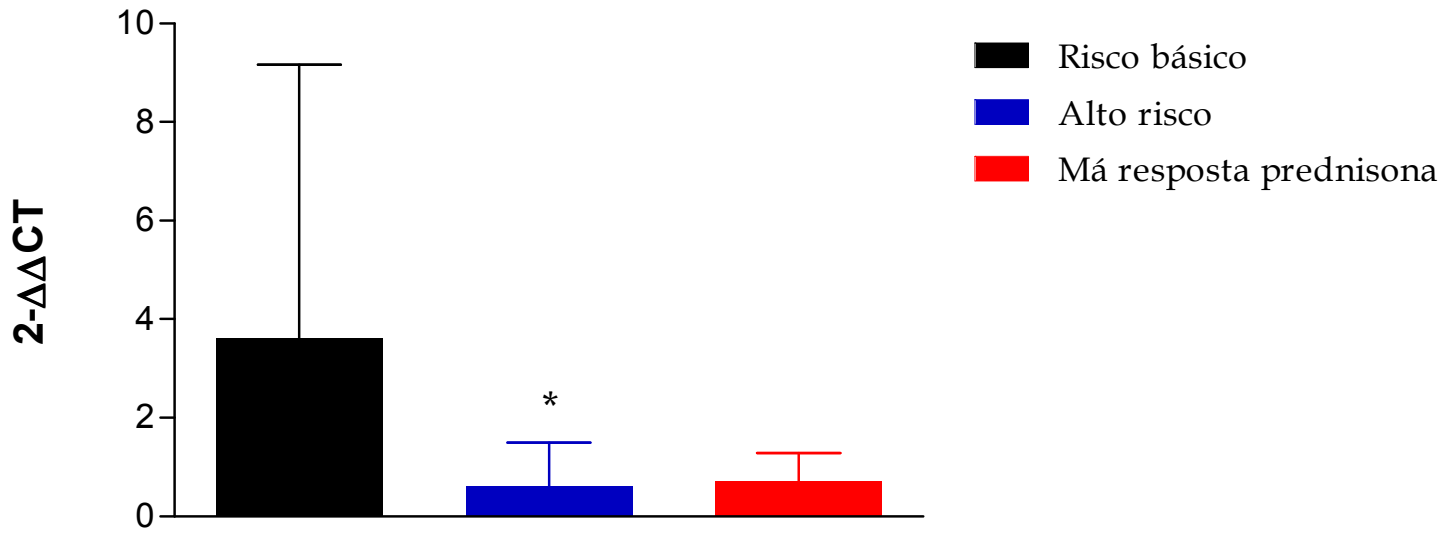

SHOC2

Figura 16. Perfil de expressão do gene $S H O C 2$ entre os pacientes de riscos básico e alto e pacientes com lenta resposta à prednisona. Risco básico vs maus respondedores apresentaram $\mathrm{p}=0,009$ e alto $\equiv$vsmausrespondedores $\mathrm{p}=0,06$.

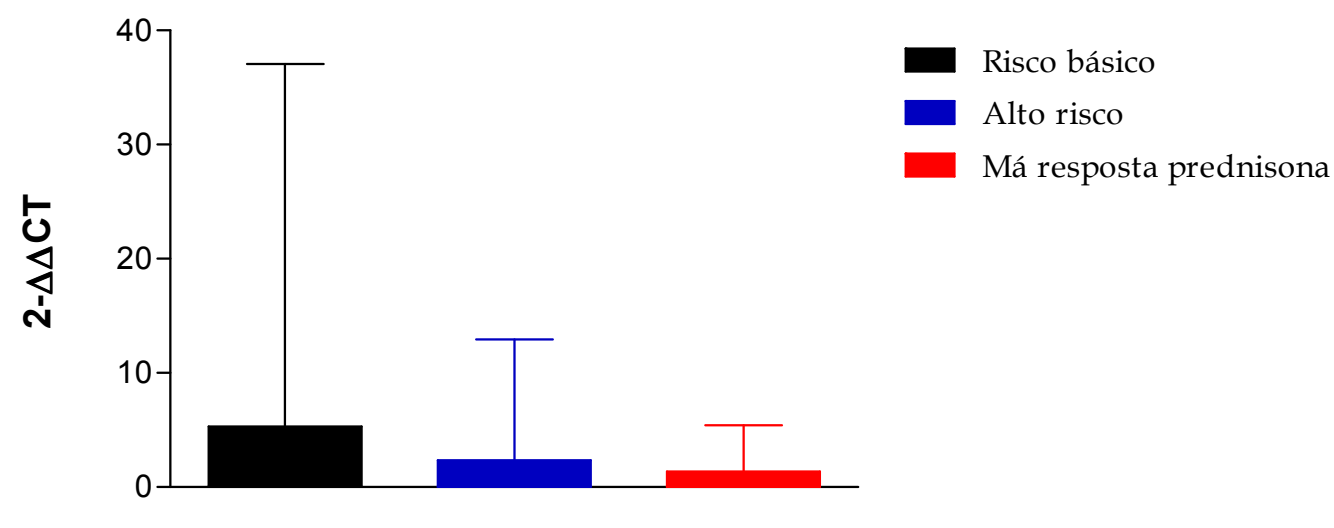

GPR56

Figura 17. Perfil de expressão do gene GPR56 entre os pacientes de riscos básico, alto e pacientes com lenta resposta à prednisona. Risco básico vs maus respondedores apresentaram $p=0,20$ e alto risco $v$ s maus respondedores $p=0,83$. 
Para verificar a relação entre a expressão dos genes estudados e as variáveis clínicas realizou-se a análise comparativa entre a expressão dos genes SHOC2 e GPR56 e as variáveis: idade (entre 1-9 anos versus <1 ano/>9 anos), número de glóbulos brancos ao diagnóstico (maior ou menor que 50000/ $\mathrm{mm}^{3}$ ) e presença de doença residual mínima no trigésimo terceiro dia da indução. A análise do perfil de expressão do gene $S H O C 2$ em relação ao número de glóbulos brancos ao diagnóstico não apresentou diferença significativa $(p=0,06)$ e o mesmo ocorreu para o gene GPR56 $(\mathrm{p}=0,11)$. A figura 18 representa os resultados encontrados para essa análise. Com relação à idade e à DRM também não observamos diferença significativa ( $p=0,35$ e $p=0,27$ para o gene SHOC2 e $p=0,15$ e $p=0,48$ para o gene GPR56, respectivamente).

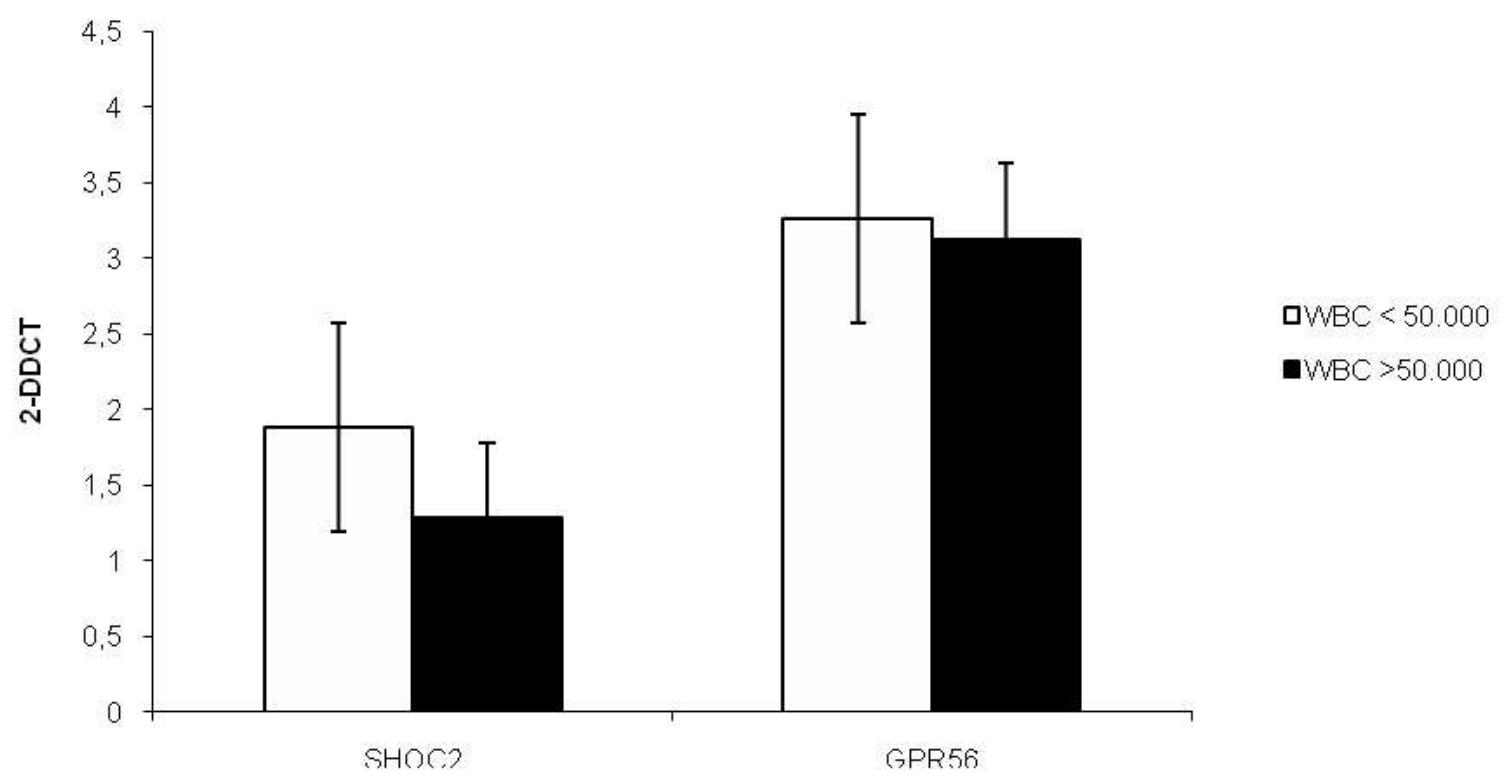

Figura 18. Perfil de expressão dos genes $S H O C 2$ e GPR56 em relação à contagem inicial de glóbulos brancos (WBC); $\mathrm{p}=0,06$ e $\mathrm{p}=0,11$ respectivamente). 


\subsection{ANÁLISE DA EXPRESSÃO PROTÉICA DO GENE SHOC2}

Após a análise do perfil de expressão dos 19 genes descritos anteriormente e da análise dos genes SHOC2 e GPR56 nos pacientes de LLA submetidos ao protocolo de tratamento do BFM-2000, decidiu-se avaliar a expressão protéica do gene SHOC2 por ter se mostrado o gene mais promissor como possível candidato a marcador prognóstico.

Para avaliar a expressão protéica do gene SHOC2 foram estudadas 50 amostras de LLA de pacientes submetidos ao protocolo de tratamento do GBTLI-99. Avaliou-se também a expressão protéica da amostra de medula óssea normal utilizada inicialmente como calibrador na análise de expressão gênica por RT-PCR em tempo real. Como controle endógeno do experimento foi avaliada a expressão da proteína GAPDH e como controle positivo da expressão protéica do SHOC2 foi utilizado o lisado protéico da linhagem celular leucêmica Jurkat, que sabidamente apresenta elevada expressão de tal proteína.

As amostras de proteína dos pacientes portadores de LLA foram divididas em dois grupos baseando-se no perfil de expressão gênica. As amostras que apresentaram níveis de expressão abaixo da mediana foram consideradas como hipoexpressas e da mesma maneira, as que apresentaram expressão acima da mediana foram consideradas como hiperexpressas.

Dentre as amostras pertencentes aos dois grupos analisados observamos uma correlação altamente significativa entre o perfil de expressão do gene SHOC2 e a expressão protéica. Quando avaliamos o grupo de pacientes que 
apresentaram baixos níveis de expressão do gene SHOC2, verificamos que $84 \%$ das amostras analisadas apresentavam hipoexpressão da proteína comparadas à expressão do controle endógeno. Por outro lado, a análise do grupo de pacientes que apresentou níveis de expressão significativamente elevados quando avaliado por RTPCR em tempo real, apresentou um índice de expressão protéica de 97\%, mostrando uma correlação extremamente significativa entre a expressão gênica e a expressão protéica do gene SHOC2. A figura 19 ilustra a expressão gênica do gene $S H O C 2$ e a validação da expressão protéica através de western blotting. 
A)

\section{Expressão gênica $\mathrm{SHOC2}$}

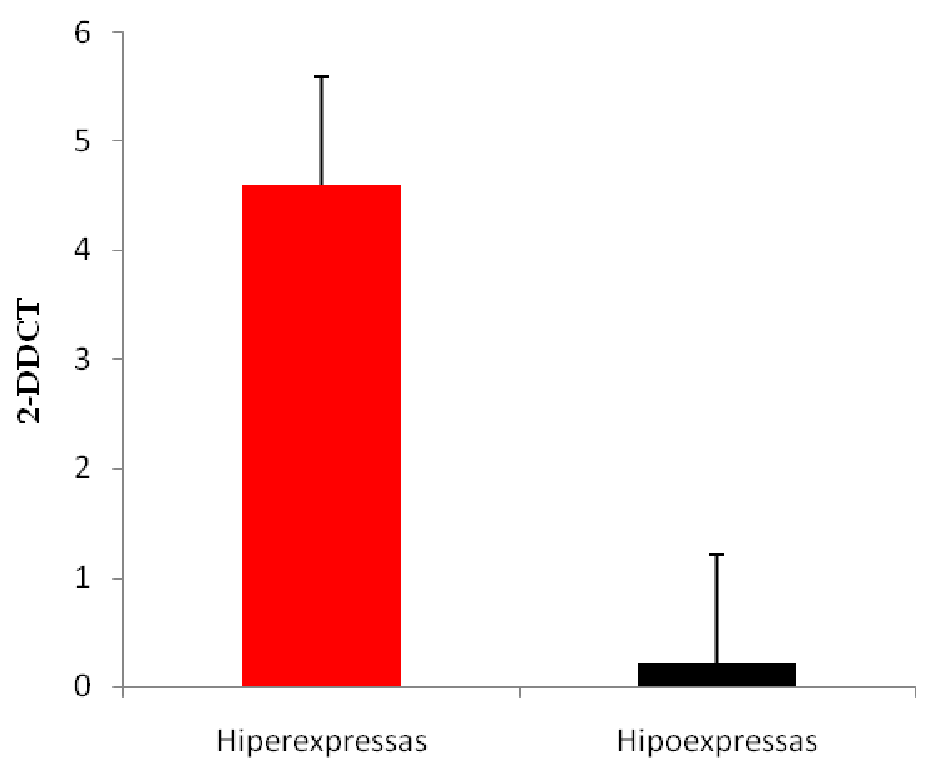

Hiperexpressas

- Hipoexpressas

B) Hiperexpressas

Hipoexpressas

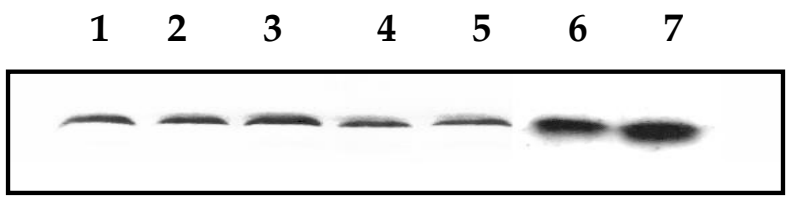

1

34

$\begin{array}{lll}5 & 6 & 7\end{array}$

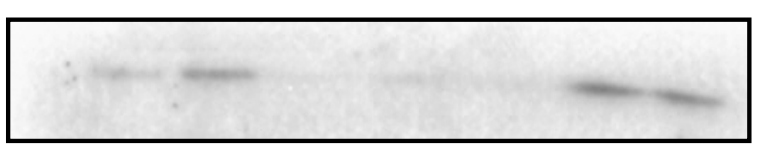

SHOC2

$(65 \mathrm{kDa})$
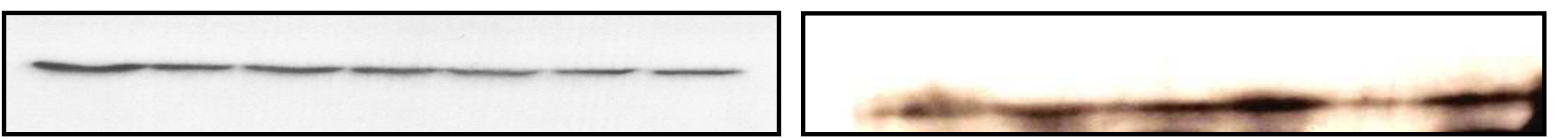

GAPDH

$(40 \mathrm{kDa})$

Figura 19. Perfil de expressão do gene SHOC2. A) Perfil de expressão gênica através de RTPCR quantitativa e B) Confirmação da expressão protéica através da análise realizada por 三tern blotting. 


\subsection{SILENCIAMENTO DO GENE SHOC2 POR RNAI}

Com o intuito de verificar o papel da proteína SHOC2 no processo de sensibilidade às drogas, realizou-se o silenciamento do gene SHOC2 para determinar o efeito da supressão gênica na linhagem celular leucêmica Jurkat. Suspensões de células Jurkat foram transfectadas com o siSHOC2 e com o siRNA controle negativo e coletadas após 48 horas para análise de expressão do RNAm, e após 24, 48, 72 e 96 horas para análise da expressão protéica. Outro controle realizado foi a manutenção da cultura celular somente com o agente utilizado na transfecção, a lipofectamina. Quando comparadas com as células Jurkat mantidas normalmente em meio de cultura RPMI, a transfecção com o siRNA controle negativo assim como as células mantidas em meio com lipofectamina não apresentaram alteração da expressão gênica e protéica referente ao SHOC2.

As células Jurkat transfectadas com o siSHOC2 apresentaram uma redução na expressão gênica de $83 \%$ em relação ao siRNA controle negativo e às células não transfectadas após 48 horas. O ensaio de silenciamento gênico através do siRNA está representado na figura 20.

Para a verificação da supressão protéica foram coletadas amostras de proteínas das células transfectadas com siSHOC2, transfectadas com o siRNA controle negativo e somente com o lipofectamina. A supressão da expressão protéica foi observada 96 horas após a transfecção (Figura 21). 


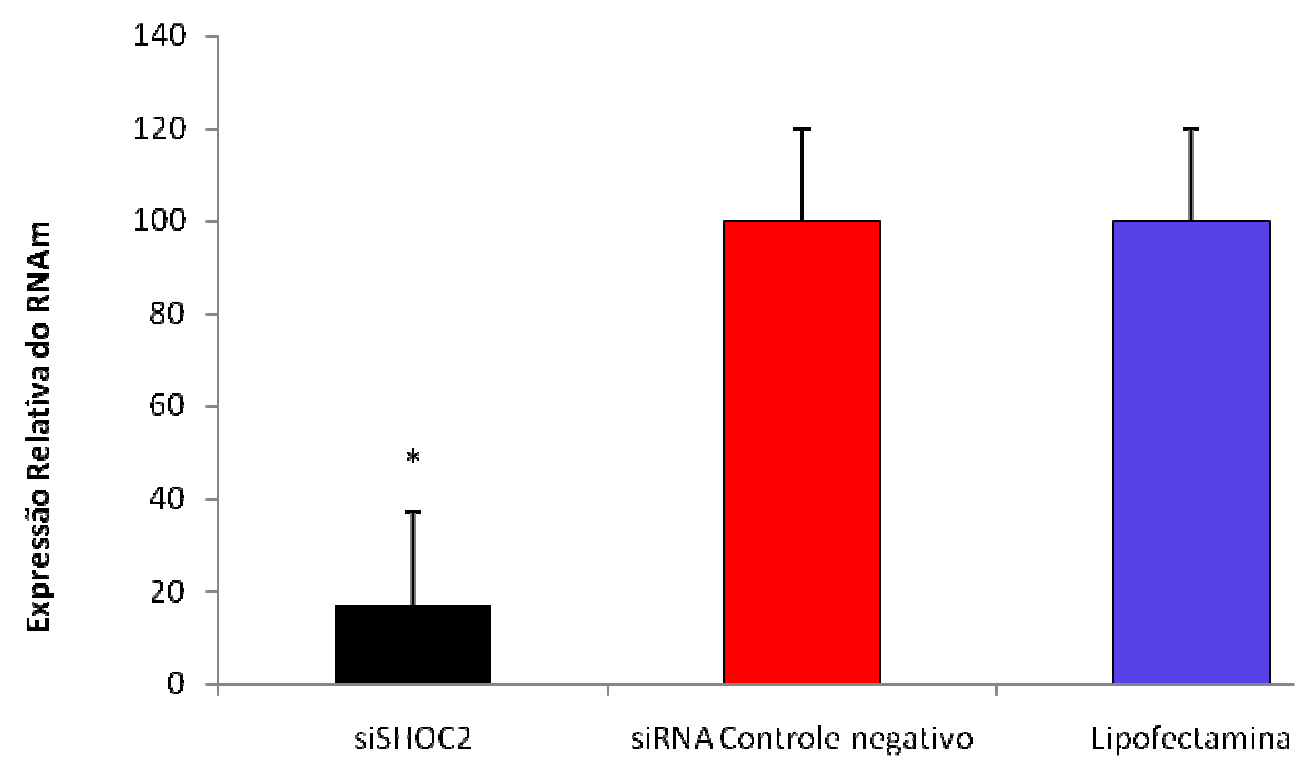

Figura 20. Silenciamento gênico do gene SHOC2. Silenciamento gênic $\equiv$ dução de $83 \%$ na expressão gênica do gene SHOC2 48 horas após a transfecção com o sisHOC2. Os dados representam a média de três experimentos independentes.

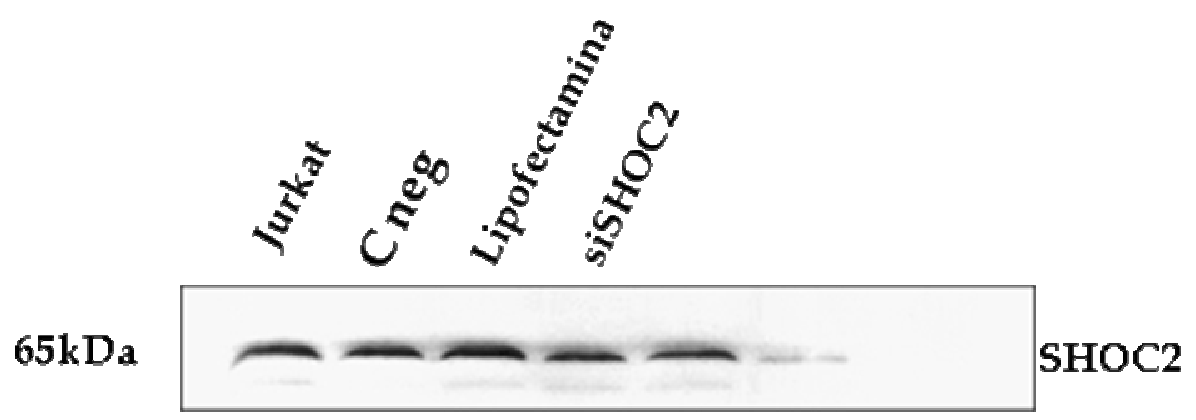

24h $48 h 72$ h $96 h$

Figura 21. Western blotting para análise da expressão protéica da proteína SHOC2. supressão protéica foi verificada 96 horas após a transfecção. A expressão de GAPDH fơ utilizada como controle. 


\subsection{ENSAIO DE PROLIFERAÇÃO E VIABILIDADE CELULAR $\equiv$}

A linhagem celular Jurkat foi cultivada em meio RPMI suplementado com SBF (10\%) assim como as linhagens transfectadas com o siSHOC2 e o siRNA controle negativo. Todas as linhagens foram cultivadas em placa com uma contagem inicial de $1,0 \times 10^{3}$ células e avaliadas nos tempos 24, 48, 72 e 96 horas após a transfecção. A linhagem Jurkat assim como a linhagem transfectada com o siRNA controle negativo apresentaram taxa de proliferação constante ao longo das 96 horas avaliadas, sendo que houve um pico de proliferação após 72 horas seguido de redução da proliferação quando avaliadas após 96 horas.

A linhagem celular transfectada com o siSHOC2 no entanto, apresentou uma significativa redução na proliferação quando comparada à linhagem celular normal (não transfectada) observada 24 e 48 horas após a transfecção ( $p=0.0005$ e p=0,05, respectivamente). Quando comparada ao controle negativo, a linhagem Jurkat transfectada apresentou uma redução significativa na proliferação 24 horas após a transfecção $(p=0,03)$. Nos demais tempos analisados, embora a curva de crescimento demonstre uma clara redução na proliferação das células transfectadas, não foi observada diferença estatística. As curvas de proliferação estão demonstradas na figura 21.

O teste de viabilidade celular demonstrou que todas as linhagens apresentaram índices de viabilidade celular equivalentes a $85 \%$ ao longo das primeiras 72 horas e todas apresentaram um decréscimo na viabilidade celular no último tempo analisado (96 horas). Embora a viabilidade celular tenha reduzido, as linhagens celulares transfectadas ou não, apresentaram índices de viabilidade semelhantes (61\%). 


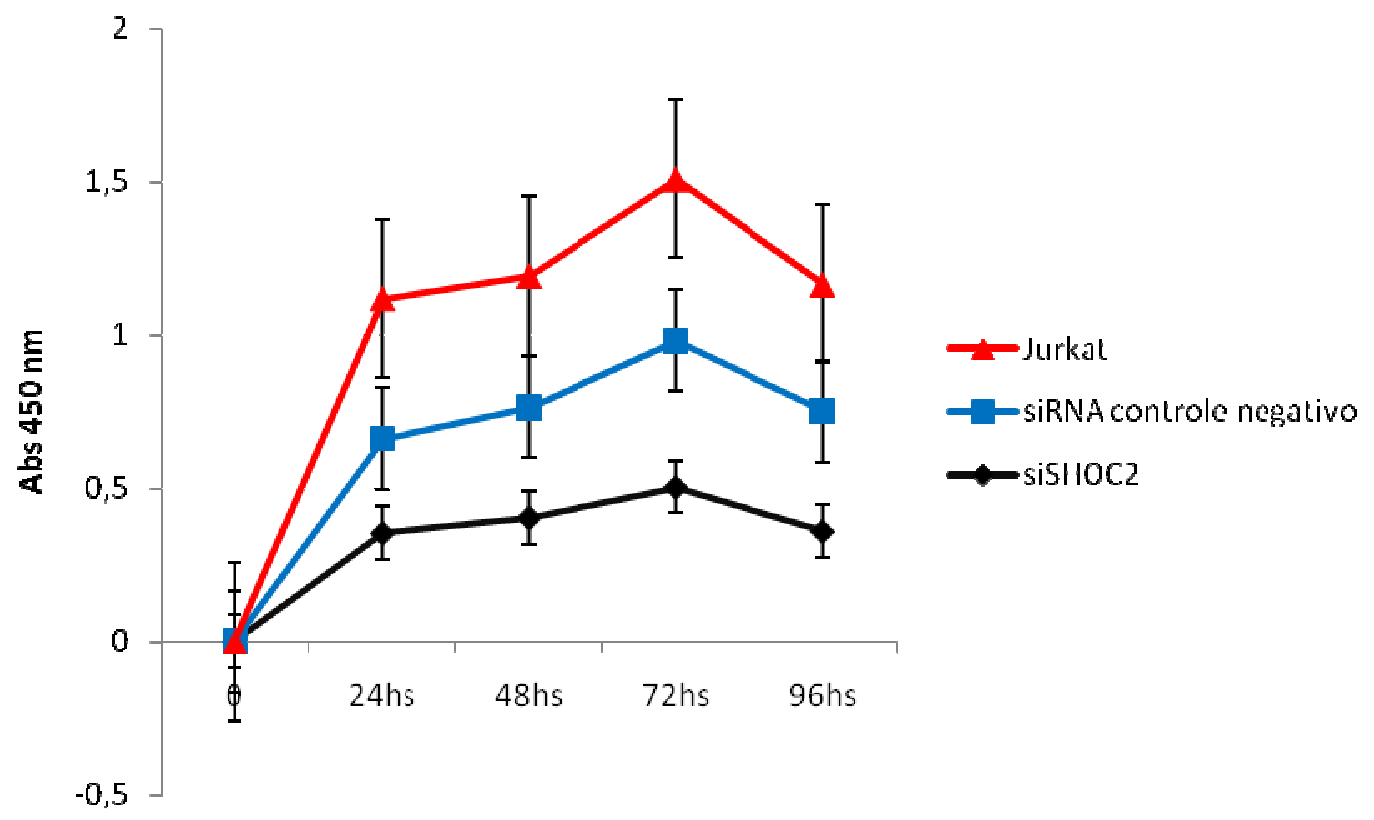

Figura 22. Proliferação celular da linhagem Jurkat. Padrão de proliferação obtido após a transfecção das linhagens com o siSHOC2 e com o siRNA controle negativo em relação à linhagem celular normal (não transfectada). O gráfico representa os dados obtidos através da média de três experimentos independentes (desvio padrão <0,05). 


\subsection{ENSAIO DE INDUÇÃO DE APOPTOSE}

Após verificarmos a redução da viabilidade celular através da transfecção com o siRNA, tornou-se importante avaliar se a mesma estava ocorrendo por meio da indução de apoptose ou simplesmente por indução de necrose celular. As linhagens foram então transfectadas com o siSHOC2 e com o siRNA controle negativo e analisadas 96 horas após a transfecção (tempo em que foi comprovada a repressão da expressão protéica do gene $S H O C 2)$. Além destas, analisamos também a linhagem Jurkat que foi utilizada como parâmetro normal.

O ensaio de indução de apoptose confirmou o índice de necrose celular indicado pelo ensaio de viabilidade, mostrando que a redução da viabilidade ocorreu pela presença de necrose celular e não pela indução de apoptose. Quando comparamos o número de células apoptóticas entre a linhagem celular transfectada com siSHOC2 e as linhagens transfectada com o siRNA controle negativo e a linhagem Jurkat não transfectada, não foram observadas diferenças estatisticamente significativas $(p=1,0$ e $p=0,21$ respectivamente). Por outro lado, ao analisar a porcentagem de células viáveis observou-se uma diferença significativa entre a linhagem transfectada com o siSHOC2 em relação à linhagem celular normal $(p=0,01)$ e ao controle negativo, transfectada com o siRNA controle, $(p=0,04)$. Os dados referentes a essa análise estão destacados na figura 22. 


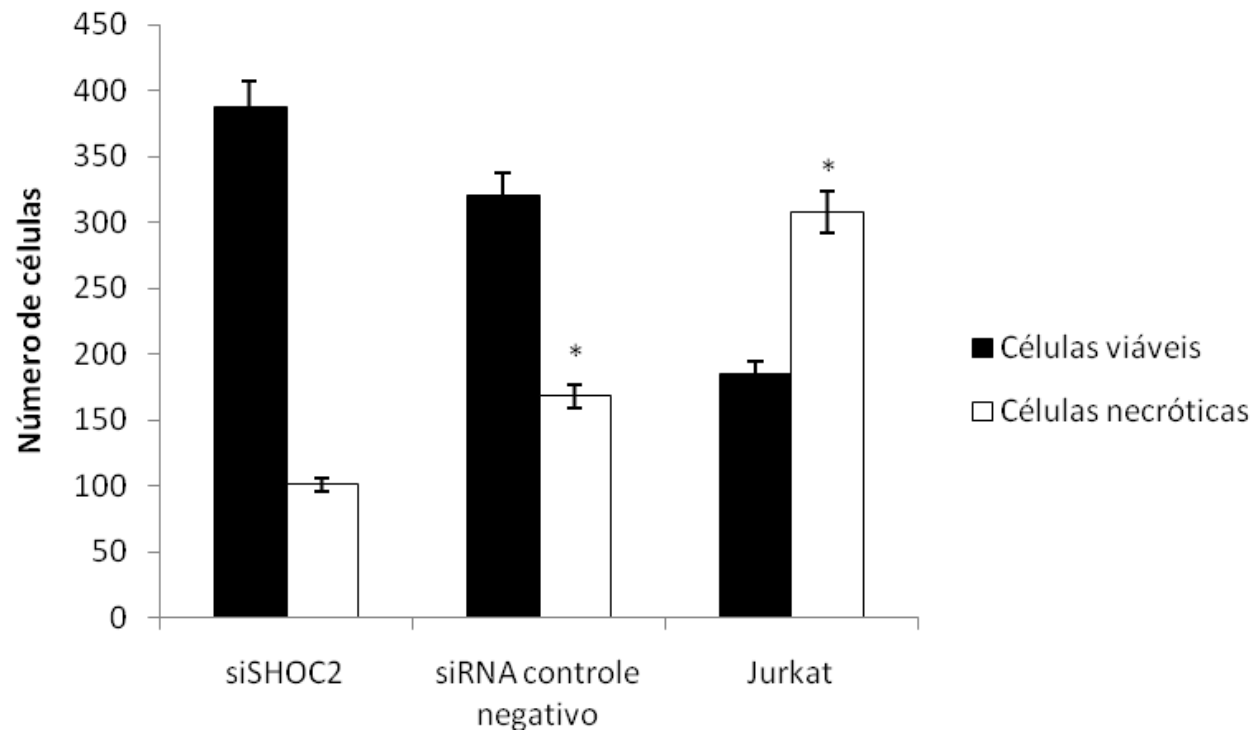

Figura 23. Ensaio $\equiv$ viabilidade celular. Padrão de necrose celular $\equiv$ aliados 96 horas após a transfecção demonstrando a redução da porcentagem de necrose celular entre a linhagem transfectada com siSHOC2 em relação ao controle negativo $(p=0,02)$ e à linhagem normal não transfectada $(p=0,01)$. 


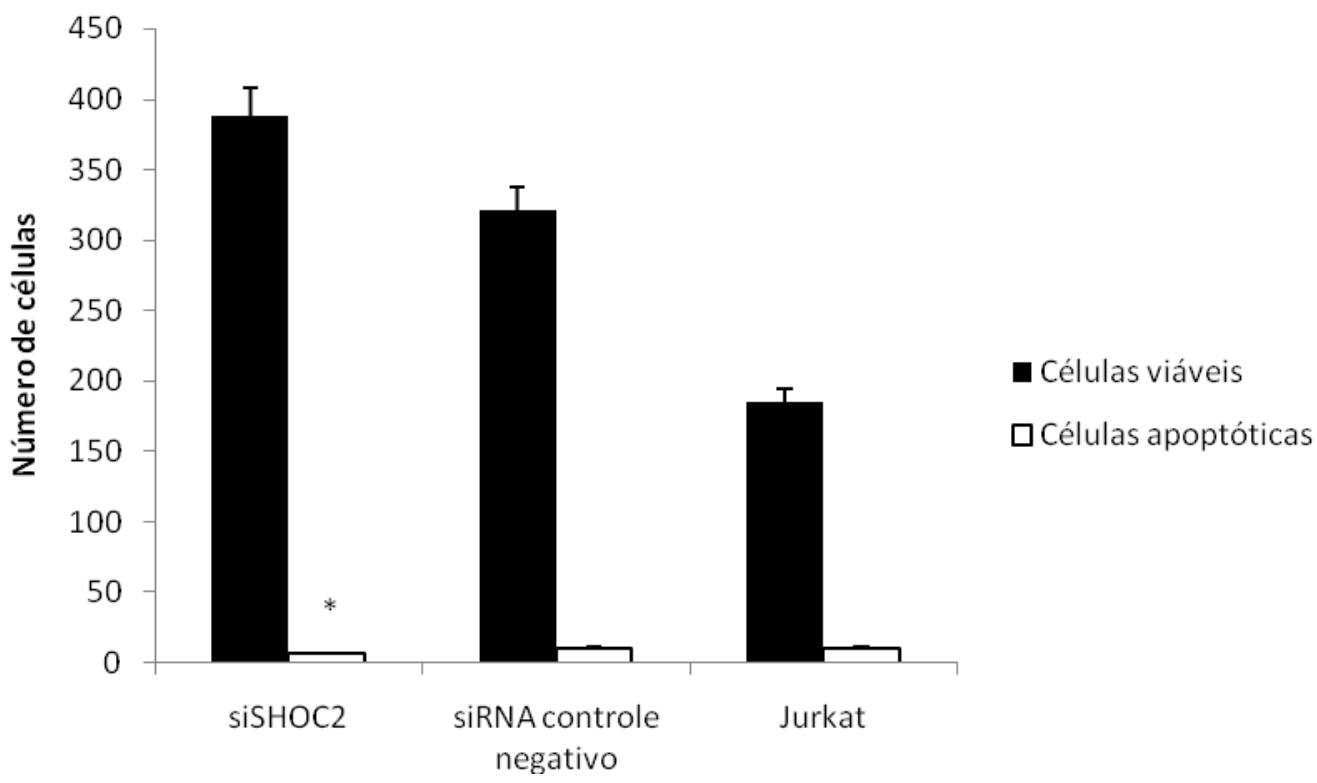

Figura 24: Ensaio $\equiv$ ndução de apoptose. Padrão de indução de apoptose $\equiv$ liado 96 horas após a transfecção đemonstrando a redução da porcentagem de apoptose entre a linhagem transfectada com siSHOC2 em relação ao controle negativo $(p=0,50)$ e à linhagem normal não transfectada $(p=0,03)$. 
Discussão 


\section{DISCUSSÃO}

\subsection{ANÁLISE DO PERFIL DE EXPRESSÃO GÊNICA}

Holleman e colaboradores (2004), através de microarranjos de oligonucleotídeos, determinaram uma série de genes cuja expressão está associada à resistência ou sensibilidade aos diferentes quimioterápicos normalmente utilizados na fase de indução do tratamento de LLA: prednisona, vincristina, L-asparaginase e daunorrubicina, demonstrando que o padrão de expressão gênica apresentou-se associado com a evolução clínica dos pacientes. Com o intuito de confirmar a expressão gênica desses genes e identificar possíveis marcadores prognósticos, o presente trabalho avaliou crianças e adolescentes portadores de LLA em relação à expressão gênica de 19 genes.

\subsubsection{Padrão de expressão dos genes associados à prednisona}

Dentre os genes envolvidos com a resistência e/ou sensibilidade ao quimioterápico prednisona estão os genes: $F 8 A, C D K 2 A P 1, B L V R B$ e CD69.

O gene F8A, responsável pela codificação do fator de coagulação sanguínea 8, foi inicialmente descrito em 1984 (Toole et al., 1984) e mutações nesse gene acarretam a hemofilia, que representa a desordem de coagulação mais frequentemente descrita. O fator VIII é um heterodímero não covalente formado de 
uma cadeia pesada e uma cadeia leve. Os íons metálicos são críticos para a integridade do fator VIII, sendo que os íons $\mathrm{Cu}$ e $\mathrm{Ca}^{++}$são responsáveis, respectivamente, por estabilizar o heterodímero e gerar a conformação ativa do fator. A ativação do fator VIII, catalisada pela trombina, parece ser dependente de interações com ligantes aniônicos que convertem o heterodímero para o cofator ativo, conhecido como FVIIIA (Fay, 2006). No presente trabalho não foi observada nenhuma associação entre a expressão do gene $F 8 A$ e os parâmetros clínicos analisados. Por outro lado, embora esse dado não tenha relatado nenhuma associação significativa, ele se mostra importante visto que a real participação do gene F8A em processos de resistência e sensibilidade aos quimioterápicos ainda permanece desconhecida e até o presente momento não tem sido relatada pela literatura.

CDK2AP1, também conhecido como p12DOC-1 é um gene supressor de crescimento altamente conservado e que foi identificado e isolado de queratinócitos normais (Todd et al., 1995). Estudos têm demonstrado que a P12 pode inibir a replicação do DNA através da ligação à DNA polimerase a-primase (Matsuo et al., 2000) e mais recentemente foi demonstrada também sua interação com a regulação de quinases dependentes de ciclina (cdks). A P12 está associada com a regulação negativa da atividade da CDK2, pelo seqüestro do pool monomérico (inativo) de CDK2 e sinalizando a CDK2 para a proteólise em condições de superexpressão da P12 nas células (Hu et al., 2004).

No presente estudo, a análise do perfil de expressão do gene CDK2AP1 mostrou um padrão elevado de expressão entre os pacientes de LLA do tipo B em 
relação aos portadores de LLA do tipo T, sugerindo que a hiperexpressão desse gene poderia ser correlacionada como fator de prognóstico favorável em leucemia, visto que normalmente as leucemias do tipo B apresentam melhor prognóstico em relação às leucemias do tipo $\mathrm{T}$. Outras associações da expressão da P12 com fatores prognósticos já foram descritas pela literatura em diferentes tipos de câncer. Shintani e colaboradores (2001) demonstraram que em carcinomas orais de células escamosas a redução ou a perda da expressão da P12 esteve associada com graus elevados de invasão tumoral, além de piores índices de sobrevida dos pacientes. Além disso, a hiperexpressão do gene foi relacionada com a redução do crescimento celular e a indução de apoptose, os quais provavelmente podem ser indicados como responsáveis pela presença de fenótipos menos invasivos e a baixa agressividade tumoral descritas em neoplasias como câncer de próstata e câncer gástrico (Zolochevska; Figueiredo, 2009; Choi et al., 2009; Hiyoshi et al., 2009). No entanto, apesar dos nossos achados e das diversas associações concordantes relatadas pela literatura, a relevância fisiológica da interação entre a P12 e a CDK2 não somente em leucemia como nas neoplasias em geral ainda precisa ser elucidada.

A biliverdina redutase é uma enzima oxidoredutase responsável por catalisar o último passo da degradação heme, convertendo o produto heme degradado, biliverdina, em bilirrubina. Pode ser classificada em duas isoformas de acordo com a especificidade do substrato: biliverdina IX alfa redutase e biliverdina IX beta redutase (Komuro et al., 1996). A biliverdina IX beta redutase (BLVRB), catalisa a produção, dependente de pirimidina, de bilirrubina IX beta, que é o maior catabólito heme durante o desenvolvimento fetal inicial e que no adulto apresenta 
também atividade como redutase férrica (Pereira et al., 2001). No presente trabalho, observou-se um perfil de expressão elevado do gene $B L V R B$ relacionado com a baixa contagem de glóbulos brancos ao diagnóstico $\left(<50.000 / \mathrm{mm}^{3}\right)$. O alto índice de expressão gênica do $B L V R B$ pode sugerir consequentemente, um aumento da bilirrubina que embora não tenha sido associada a nenhum tipo de neoplasia, já foi descrita participando de processos como a inibição da resposta imune de linfócitos humanos, produção de interleucina2 e citotoxidade celular mediada por anticorpos.

Além disso, a bilirrubina pode atuar não somente como antioxidante, mas também pode inibir a fosforilação protéica e a atividade de enzimas como a proteína quinase C e a NADPH oxidase, que uma vez inibida pode causar depleção de NADH e consequentemente causar o bloqueio da formação de radicais livres e depleção de ATP, acarretando, por exemplo, a apoptose de células tumorais (Saito et al., 1995; Maines et al., 1999; Whitby et al., 2002).

Último gene associado à prednisona a ser analisado, o gene CD69 codifica um antígeno indutor de ativação, que atua como receptor de transdução de sinais e faz parte do complexo de células da família natural killer (NK). A CD69 é uma glicoproteína transmembrana do tipo II e sua expressão é induzida in vitro na maioria das células da linhagem hematopoiética incluindo linfócitos B e T, células NK, macrófagos, eosinófilos e neutrófilos, enquanto nos humanos é constitutivamente expressa nos monócitos plaquetas e células de Langerhans (Marzio et al., 1999). Além disso, relatos da literatura demonstraram que as células B secretam imunoglobulina e produzem citocinas depois de interagirem com as células 
NK, ilustrando a importância da interação entre essas duas linhagens celulares (Cho et al., 2004).

Nossos dados mostraram uma associação significativa entre a hiperexpressão da molécula CD69 e os pacientes que apresentaram DRM positiva no $28^{\circ}$ dia após a indução, sugerindo que o aumento da expressão desse gene pode estar relacionado com algum tipo de resistência ao tratamento, acarretando um pior prognóstico e consequentemente uma elevada possibilidade de recaída. Outros autores como Cho e colaboradores (2004) encontraram achados semelhantes ao investigarem o mecanismo de resistência à quimioterapia citotóxica em culturas de células NK e em células Raji. Eles verificaram que na presença de células NK, as células Raji adquiriram resistência à doxorrubicina, além de detectar a upregulation da CD69 nessas células, sugerindo a participação das células NK e da molécula CD69 no processo de resistência à doxorrubicina.

Outro dado interessante, apresentado por Hantschel e colaboradores (2008), demonstra a hiperexpressão de CD69 em presença da translocação $B C R-A B L$ em pacientes portadores de leucemia mielóide crônica e a posterior queda de expressão após tratamento com inibidores de $B C R-A B L$ sugerindo ainda a participação da molécula CD69 como marcador da atividade $B C R-A B L$. Estes relatos da literatura, juntamente com os dados descritos no presente trabalho, embora muito interessantes, indicam ainda a necessidade de maiores investigações para elucidar a exata função do gene CD69 em leucemias. 


\subsubsection{Padrão de expressão dos genes associados à vincristina}

Dentre os genes analisados nesse estudo e associados à vincristina estão: CD44, RPLP2, TCFL5, KCNN1 e TRIM24.

A CD44, principal receptor de ácido hialurônico (HA) em diversos tipos celulares (Underhill, 1992), é uma glicoproteína transmembrana que pertence à família de moléculas de adesão e inicialmente foram tidas como mediadoras de linfócitos aos tecidos linfóides periféricos. Na análise do perfil de expressão realizada neste trabalho, observou-se apenas a associação do perfil de expressão elevado entre pacientes CALLA negativos $(p=0,03)$, sugerindo a participação desse gene como um marcador de prognóstico desfavorável. Atualmente a participação das moléculas de CD44 desencadeando processos fisiológicos e patológicos tais como interações célulacélula e célula - matriz extracelular, migração celular e apresentação de quimiocinas e fatores de crescimento, já é bem reconhecida. Além disso, a CD44 pode participar da ativação de leucócitos, hematopoiese e ainda da propagação metastática de células tumorais, o que também poderia caracterizar a participação dessa molécula como fator prognóstico (Lesley et al., 1993; Naor et al., 1997; Kincade, et al., 1997; Bourguignon et al., 1998; Jothy, 2003). No entanto, o papel preciso da CD44 como elemento regulatório no crescimento e invasão tumoral, bem como seu papel no processo de resistência a drogas, ainda não foi claramente descrito pela literatura.

RPLP2 que codifica a proteína ribossomal P2, que desempenha um importante papel no processo de elongação durante a síntese protéica. Já foi previamente descrita em células mutantes de câncer pancreático, apresentando-se 
significativamente hiperexpressa (Künzli et al., 2007), entretanto não existem outros relatos na literatura a respeito do seu padrão de expressão. Os dados apresentados neste trabalho também não observaram nenhuma alteração no seu perfil de expressão.

O gene TCFL5 codifica um fator de transcrição, também conhecido como Cha, pertencente à família bHLH (basic helix-loop-helix). A região HLH do fator Cha apresenta um domínio de dimerização (Myc-type) necessário para a formação de heterodímeros entre os membros dessa classe. Neste trabalho observamos um aumento de expressão do gene TCFL5 entre pacientes bons respondedores e que apresentavam a translocação TEL/AML1 sugerindo a participação desse gene como um fator de bom prognóstico para os pacientes portadores de LLA. Em contrapartida, observou-se também que a hiperexpressão gênica esteve associada com a presença de DRM no $28^{\circ}$ dia após a indução. Sabe-se que tanto o RNAm como a proteína Cha, são expressos ubiquamente em diversos tecidos humanos, podendo explicar a presença da expressão elevada mesmo quando comparamos os pacientes portadores de LLA estratificados por variáveis clínicas. Já foi relatada ainda, a participação da proteína Cha em células $\mathrm{T}$ onde a hiperexpressão protéica reduz a expressão da molécula CD2 (gene upstream stimulatory factor (USF) dependente), indicando que a proteína Cha pode ser um novo fator de transcrição que regula negativamente a transcrição USF dependente (Rodríguez et al., 2003). No entanto, até o presente momento, não existem dados na literatura, que descrevam a real participação desse gene em processos neoplásicos e em processos de resistência a quimioterapia, que possam explicar a discrepância dos dados obtidos. 
Outro gene que teve o perfil de expressão analisado foi o gene TRIM24. A proteína por ele codificada é responsável pelo controle transcricional por meio da interação com a região de ativação de função (conhecida como AF2) de diversos receptores nucleares, como estrógeno, ácido retinóico e receptores de vitamina D. Já foram descritas duas variantes derivadas de splicing alternativo do gene, sendo uma delas (HTIF1 alpha) um coativador de transcrição capaz de mediar a atividade RARalpha e interagir com o gene PML (região conhecidamente crítica na leucemia mielóide aguda). A análise da expressão do gene TRIM24 no presente estudo apresentou índices elevados entre pacientes com medula M1 no $28^{\circ}$ dia após a indução e pacientes TEL/AML1 positivos. Além disso, observamos uma associação significativa entre a expressão aumentada do gene e a presença de DRM no $28^{\circ}$ dia, indicando o possível papel do gene como um marcador prognóstico. Esses dados, porém, não podem ser explicados por ser este o primeiro trabalho a caracterizar o perfil de expressão desse gene em pacientes portadores de LLA. Outros autores como Gandini e colaboradores (2002) demonstram que a hiperexpressão da variante HTIF1alpha esteve presente entre pacientes portadores de LMA subtipo M1, além de descreverem o alto índice de expressão entre células de linhagem mielóide, sugerindo a participação desse gene no processo de diferenciação mielóide. Entretanto, ainda são necessárias investigações que possam elucidar a função do gene TRIM24 em neoplasias e em processos de resistência ao tratamento quimioterápico.

A análise do último gene associado ao quimioterápico vincristina, o gene $K C N N 1$, mostra diversas associações positivas entre a hiperexpressão do gene e 
diversas variáveis clínicas como presença do antígeno CALLA, a presença da translocação TEL/AML1 e também de DRM. Observou-se ainda uma freqüência elevada de expressão entre pacientes com LLA do tipo T. A proteína codificada por esse gene é uma proteína de membrana que forma um canal de cálcio voltagem independente e é membro da família KCNN de canais de potássio (Litt et al., 1999). Até o presente momento a literatura não dispõe de dados que corroborem com os dados encontrados neste trabalho, sendo este o primeiro a descrever o perfil de expressão do gene KCNN1 em LLA. Por outro lado, é muito importante ressaltar que os dados encontrados, embora muito interessantes e estatisticamente significativos, demonstraram um baixíssimo nível de expressão do gene $K C N N 1$, fato que deve ser levado em consideração.

\subsubsection{Padrão de expressão dos genes associados à L- asparaginase}

Dentre os genes envolvidos com a resistência e/ou sensibilidade ao quimioterápico L-asparaginase foram analisados os seguintes: MAN1A1, CLEC11A, IGFBP7, GPR56,e GATA3.

Quando analisamos os genes MAN1A1 e GATA3 observamos uma associação significativa ( $p=0,05$ e $p<0,001$ respectivamente) entre o perfil de expressão e a presença do antígeno CALLA, sugerindo que a hiperexpressão desses genes poderia estar correlacionada com um fator de bom prognóstico. O gene MAN1A1 codifica a proteína transmembrana manosidase que é responsável por catalisar a hidrólise de resíduos terminais não redutores de alfa-D-manose em alfa-D- 
manosídeos além de desempenhar um importante papel no catabolismo de glicoproteínas N-ligantes por meio da degradação de oligossacarídeos (Daniel et al., 1994). Até o presente momento, não existem relatos da sua participação em leucemias que possam ser confrontados com os dados encontrados nesse trabalho. No entanto, seu valor prognóstico, embora raramente descrito pela literatura, já foi relatado em um trabalho que demonstra a hiperexpressão de MAN1A1 em adenocarcinoma de junção gastroesofágica quando comparada à mucosa gástrica normal. (Altorjay et al., 2005).

Outro gene analisado, o GATA3, além da associação com o antígeno de superfície CALLA, esteve hiperexpresso entre a LLAs do tipo B quando comparado às do tipo $\mathrm{T}(\mathrm{p}=)$. O fator de transcrição GATA3, que é expresso especificamente nas células $T$ helper 2 (Th2), desempenha um papel fundamental no processo de diferenciação dessas células (Ho et al, 1991) e já foi descrito em leucemia promieolocítica aguda, onde se apresentou significativamente hipoexpresso. Neste trabalho publicado por Rice e colaboradores (2004) foram avaliados diversos fatores de transcrição e sua relação quanto a resposta ao ácido transretinóico (ATRA), que é um inductor de diferenciação celular. Porém, embora o perfil de expressão do gene GATA3 se mostrou significativamente alterado, os autores ressaltam que os fatores de transcrição não agem individualmente como marcadores de resposta ao ATRA.

Um outro dado interessante descrito pela literatura, demonstra a amplificação do gene GATA3, por meio de análise genômica comparativa (CGH) em leucemias agudas secundárias em linfomas não Hodkin (Brusa et al., 2007). Uma outra tentativa no intuito de elucidar o papel do gene GATA3 foi a análise do perfil 
de expressão do gene somente entre pacientes com LLA do tipo T. No entanto, não foi encontrada nenhuma associação significativa, o que demonstra que embora os dados obtidos sugerem uma participação do gene como fator prognóstico, o perfil de expressão desse fator de transcrição em LLA e sua possível participação no processo de resistência ao tratamento ainda permanecem desconhecidos.

O gene CLEC11A, que codifica uma glicoproteína membro da superfamília lecitina C-type, desempenha um papel como fator de crescimento de células progenitoras hematopoiéticas primitivas (Hiraoka et al., 2001). Embora não foram encontradas diferenças significativas em relação a expressão desse gene, no presente trabalho, a participação desse gene no processo de proliferação de células leucêmicas foi recentemente descrito (Hiraoka, 2008).

Dentre os diversos fatores de crescimento conhecidos, analisou-se também a expressão do gene IGFBP7, um fator de crescimento análogo à insulina, descrito inicialmente em linhagens celulares de meningioma, onde se encontrava hiporregulado (Murphy et al., 1993). A expressão desse gene já foi descrita em diversos tipos de neoplasias, sendo que o perfil da mesma varia desde hiper como hipo regulado de acordo com o tipo tumoral (Komatsu et al., 2000; Watson et al., 2002). Na análise do perfil de expressão desse gene em pacientes com LLA observouse um aumento significativo da expressão entre pacientes com baixa contagem de glóbulos brancos ao diagnóstico (inferior a 50.000; $\mathrm{mm}^{3}$ ). Esse dado concorda com outros relatos da literatura que descreveram o papel negativo do gene no crescimento de diversos tipo de células tumorais(Wilson et al., 2002; Mutaguchi et al., 
2003; Kato, 2000), sugerindo que o fator de crescimento IGFBP7 desempenha uma função como gene supressor tumoral.

Finalmente, o último gene, associado com o quimioterápico Lasparaginase, analisado foi o gene GPR56. Inicialmente descrito por Liu e colaboradores (1999), o gene GPR56 codifica uma proteína G pertencente à subclasse B de receptores acoplados a proteínas $\mathrm{G}$ secretin-like. As proteínas $\mathrm{G}$, em geral, estão associadas a processos como transdução de sinais e particularmente a GPR56, está associada ao processo de desenvolvimento neural (Piao et al., 2004) além de contribuir com o crescimento celular, seja ele de células normais como também de células tumorais, sendo que vários autores já descreveram a alteração do seu perfil de expressão (Ahola et al., 2002; Ikeguchi et al., 2003). Outros trabalhos anteriores demonstraram a expressão seletiva desse gene em células tronco hematopoiéticas, sugerindo a participação do mesmo no processo de desenvolvimento e de identidade celular multipotente (Terskikh et al., 2007). No presente estudo, o gene GPR56 que no trabalho inicial realizado por Holleman e colaboradores (2004) esteve associado à sensibilidade à asparaginase, se mostrou associado a fatores clínicos como baixa contagem de glóbulos brancos ao diagnóstico e também com elevada sobrevida livre de eventos $(p=$ e $p=$ respectivamente), sugerindo o envolvimento do GPR56 como fator prognóstico positivo. Por outro lado, quando se avaliou a expressão entre os pacientes submetidos ao protocolo BFM, não foi observada nenhuma diferença significativa. Os dados existentes na literatura até o presente momento, também são divergentes. 
Diversos autores demonstraram o papel oncogênico do GPR56, por meio da sua hiperexpressão em vários tecidos tumorais, dentre eles metástases ósseas de carcinomas de mama e de próstata, sugerindo que este gene promove a proliferação de células tumorais (Hoey, et al., 2003). Por outro lado, Xu e colaboradores (2006) descreveram o papel da proteína GPR56 como supressora do crescimento tumoral além da inibição do processo de metástase celular em melanomas. Essas divergências podem ser explicadas pelo fato de que a expressão do GPR56, assim como a expressão gênica como um todo, pode ser altamente variada quando analisada em diferentes tipos de tumores. Além disso, sabe-se a proteína GPR56 participa do processo de crescimento celular por meio da interação com diversas vias complexas, como por exemplo, através da ativação de membros da família MAPK (proteínas quinases ativadas por mitógeno) que consequentemente podem ativar fatores de transcrição e promover a síntese de DNA e a divisão celular (Gutkind, 2000). Entretanto, apesar dos relatos disponíveis ate o presente momento, nenhum dado relacionado à LLA ou mesmo à malignidades hematopoiéticas, foi descrito até o momento, demonstrando a importância de estudos futuros para elucidar a função da GPR56 no processo de desenvolvimento e progressão da leucemia linfóide aguda.

\subsubsection{Padrão de expressão dos genes associados à daunorrubicina}

Os genes MAP3K12, PCDH9, EGR1, KCNN4 e SHOC2 estiveram associados à daunorrubicina. As proteínas quinases ativadas por mitógeno (MAPKs) são uma família de proteínas (serinas ou treoninas), que atuam mediando os sinais 
de estímulo externo à maquinaria de processos biológicos fundamentais como crescimento, proliferação, diferenciação, migração e apoptose (Chang; Karin, 2001). O gene MAP3K12 se mostrou hiperexpresso entre as leucemias do tipo $\mathrm{T}$ quando comparado às leucemias do tipo $B(p=0,006)$. Além disso, esteve associado com o antígeno CALLA, apresentando-se hipoexpresso entre os pacientes CALLA positivos. Esses dados sugerem a participação do gene MAP3K12 com fatores de pior prognóstico em LLA. As evidencias pré - clinicas da atividade anti - leucêmica dos inibidores MAPK, sozinhos ou combinados com pequenas moléculas pro apoptóticas ou agentes quimioterápicos convencionais, fazem dos inibidores baseados nas MAPKs, estratégias de tratamento que poderiam enriquecer a terapêutica contra as leucemias humanas (Milella et al., 2004).

O EGR1 é um fator de transcrição multifuncional que regula respostas celulares desde o surgimento da célula até o processo de apoptose, como crescimento, diferenciação, transformação e senescência celular (Adamson et al., 2003). Já esteve associado juntamente com as MAPKs, como elemento regulador da transcrição de genes envolvidos na resposta à doxorrubicina, como o gene SERCA2 (Arai et al., 2000). Entretanto neste trabalho não se observou nenhuma associação significativa entre o seu perfil de expressão e fatores prognósticos importantes.

A protocaderina PCDH9 faz parte de uma subfamília de proteínas de adesão e reconhecimento célula-célula, dependente de cálcio, da superfamília de caderinas (Strehl et al., 1998). No presente trabalho observou-se a associação entre a hiperexpressão do gene $P C D H 9$ e a presença de doença residual mínima no $28^{\circ}$ dia, indicando o possível envolvimento desse gene no processo de resistência ao 
tratamento, além de caracterizar um fator de mau prognóstico uma vez que pacientes que apresentam DRM positiva apresentam chance significativamente maior de recidiva. Este achado valida os dados descritos anteriormente por Holleman e colaboradores, que também descreveram a associação deste gene com a resistência à daunorrubicina. Essa hipótese, também foi levantada por Chen e colaboradores (2002), que demonstraram a associação das protocaderinas com a resistência ao processo de apoptose em células tumorais. Entretanto, devido à escassez de dados disponíveis na literatura até o momento, estudos futuros que elucidem a participação das protocaderinas no processo de resistência à quimioterápicos em leucemias ainda são necessários.

KCNN4, também conhecido como SK4 ou KCa4, é um canal condutor intermediário de íons potássio operado pelo fluxo intracelular de íons $\mathrm{Ca}^{2+}$. A expressão de KCNN4 parece estar associada primariamente com sistemas de secreção como glândulas salivares mama, próstata e pulmões, mas também já foi descrito em células sanguíneas, epiteliais e endoteliais (Jensen et al., 2001). O papel fisiológico do KCNN4 foi recentemente caracterizado utilizando camundongos knock out, onde a deficiência do gene KNCC4 foi associada ao controle da proliferação dos linfócitos T bem como na regulação do volume de células vermelhas. Bloqueadores seletivos de KCNN4 também foram utilizados no intuito de revelar sua função no envolvimento patológico de doenças como inflamação mediada por células $\mathrm{T}$, anemia falciforme (Jensen et al., 2001; Hoffman et al., 2003) e câncer (Stocker et al., 2003). No presente trabalho, entretanto, não foi observada nenhuma alteração 
significativa na expressão desse gene que pudesse associá-lo à algum fator prognóstico importante.

O último gene avaliado, que esteve associado à sensibilidade ao quimioterápico daunorrubicina, foi o gene SHOC2. Sua participação no processo de resposta ao tratamento será discutida a parte, no item seguinte.

\subsection{PAPEL DO GENE SHOC2 - Processo de resposta ao tratamento em LLA}

No estudo feito por Holleman e colaboradores (2004) o gene SHOC2 se apresentou associado à sensibilidade ao quimioterápico daunorrubicina. No intuito de confirmar esse dado, analisou-se o seu perfil de expressão em pacientes pediátricos portadores de LLA.

\subsubsection{Análise do perfil de expressão gênica e protéica}

A análise inicial do padrão de expressão gênica mostrou um aumento significativo da expressão relacionada a dois importantes fatores prognósticos. Dentre eles a presença do antígeno CALLA e a correlação mais importante, a elevada sobrevida livre de eventos. Dentre todos os genes analisados, este foi o que mais se ressaltou, visto que pareceu estar fortemente relacionado a fatores de bom prognóstico e poderia ser considerado um importante marcador na LLA. Para confirmar essa hipótese, seria importante avaliar o perfil de expressão gênica do gene SHOC2 em um grupo diverso de pacientes. Decidiu-se então, avaliar pacientes pertencentes ao grupo AIEOP, que caracterizariam não somente um grupo amostral 
com um background genético distinto, como também permitiria a análise do perfil de resposta ao tratamento de pacientes submetidos ao protocolo BFM. Essa análise confirmou os dados obtidos inicialmente e demonstrou uma correlação altamente significativa entre a hiperexpressão do gene SHOC2 e o grupo de pacientes de risco básico e que apresentaram com boa resposta inicial ao tratamento. Finalmente, para verificar o nível de correlação do gene, posteriormente foi analisada a expressão protéica do mesmo, onde se pode confirmar a presença da proteína SHOC2 entre os pacientes de LLA, sugerindo mais uma vez que este gene pode representar um importante marcador de bom prognóstico em LLA.

O gene SOC-2 foi descrito primariamente em C. elegans e codifica uma proteína composta basicamente de repetições de leucina, um domínio que está envolvido em interações proteína-proteína. O homólogo desse gene em humanos, SHOC2, demonstra um alto grau de conservação de sequências, sugerindo que ambas as proteínas podem compartilhar importantes funções celulares (Selfors et al., 1998). Em análise da família de proteínas RAS, com o intuito de encontrar fatores possivelmente envolvidos na regulação dessa via, Derek e colaboradores (1998) descreveram o papel da proteína SOC-2, durante o desenvolvimento de C. elegans, como importante regulador da via RAS, agindo downstream, entretanto, acima da proteína RAF. A análise do homólogo humano, SHOC2 também demonstrou a possível participação da proteína na via, agindo como ligante da proteína RAS, entretanto essa ligação pareceu ser específica das formas N-RAS e K-RAS, não ocorrendo entre a forma H-RAS. 
Posteriormente, verificou-se que a proteína SHOC2 pode se ligar tanto à proteína RAS como também à RAF1. O processo de ativação da via RAS é já bastante conhecido, e sabe-se que RAS pode se ligar diretamente à RAF no processo de ativação da via. No entanto, na presença da SHOC2 essa afinidade de ligação aumenta consideravelmente e consequentemente a sinalização dos eventos subseqüentes da cascata. (Li et al., 2000). Outro dado interessante, destacado por Rodriguez-Viciana e colaboradores (2006) é o fato de que a proteína SHOC2 não é capaz de se ligar às formas mutantes de RAS. Dessa forma pode-se caracterizar a proteína SHOC2 como um importante fator de regulação para os processos normais de proliferação e diferenciação celular, visto que sua ligação com RAS e RAF para a formação de um complexo ternário mais estável, proporciona a ativação de ERK, que é a proteína efetora da via (Robinson; Cobb, 2000; Huang et al., 2003).

A importância da proteína SHOC2 na ativação da via RAS foi ainda confirmada por Rodriguez-Viciana e colaboradores (2006) que caracterizaram o complexo ternário que atua como efetor no processo de modulação da atividade de RAF. Esse complexo é formado pela proteína SHOC2 juntamente com a subunidade catalítica da enzima fosfatase 1 (PP1c). Na ausência da SHOC2 (avaliada por ensaios de RNA de interferência) a ativação de ERK foi inibida, reafirmando a participação fundamental do SHOC2 no processo de ativação de RAF. Para melhor compreensão da cascata RAS/RAF/MEK/ERK e da participação da proteína SHOC2 a figura 25 ilustra a via. 


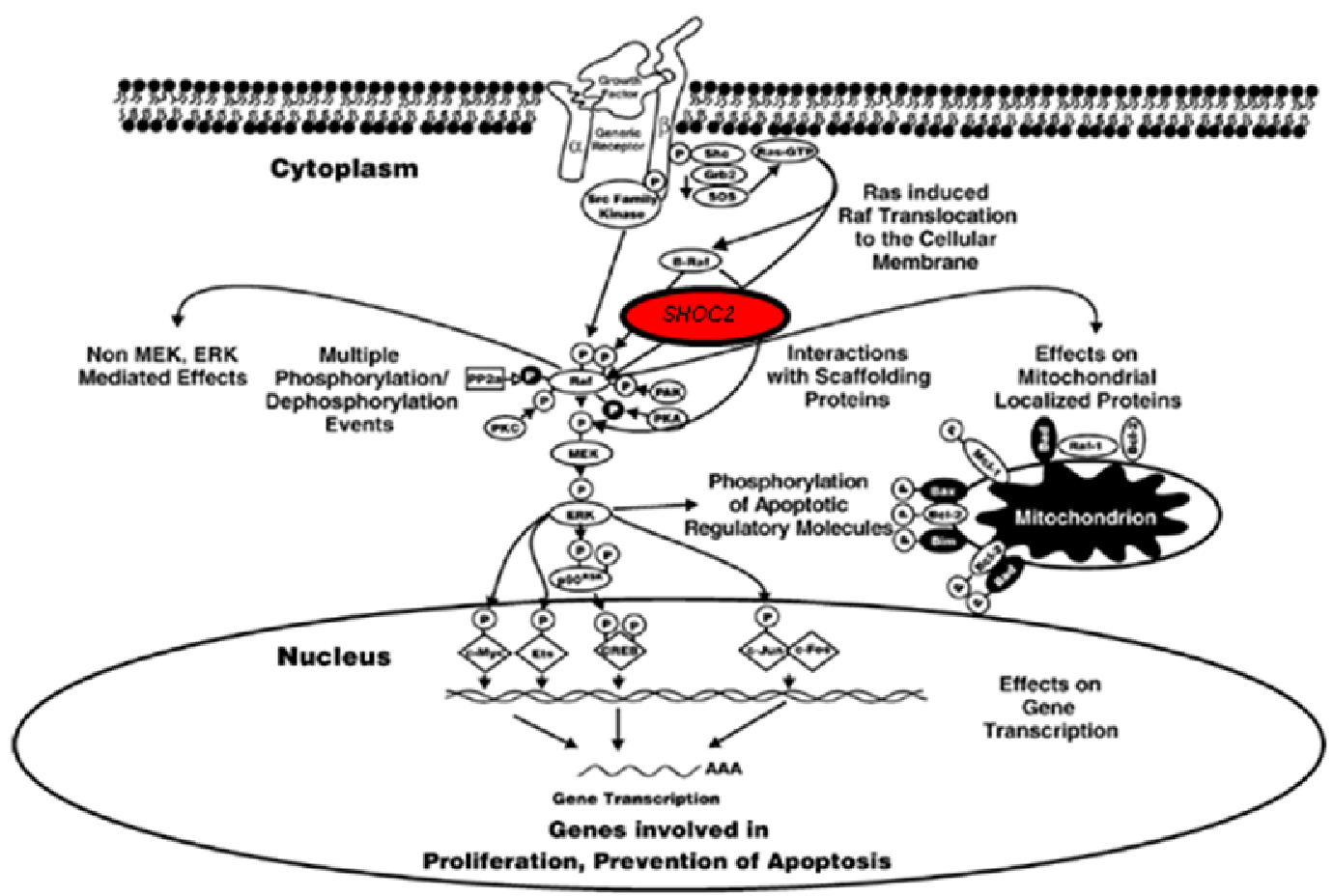

Figura 25. Via Ras/Raf/Mek/Erk. Via regulada por RAS assim como diversas outras quinases que fosforilam os resíduos de RAF. Os eventos de fosforilação podem induzir a atividade de Raf ( círculos brancos) como também para inibir ( círculos pretos). Os fatores de transcrição downstream que são regulados por essa via se encontram destacados em triângulos (Adaptada segundo McCubrey et.al., 2007).

Uma vez definida a provável função da proteína SHOC2, decidiu-se compreender melhor os mecanismos que levavam a hiperexpressão da mesma, participar de um processo de maior sensibilidade à quimioterapia, resultando em melhores índices de sobrevida entre os pacientes.

Observando-se a cascata de ativação da via Ras, pode-se notar a imensa complexidade da via. O principal efetor da via, a ERK, uma vez ativado pode participar de diversos processos biológicos e dentre eles estão a regulação da apoptose e da proliferação celular (Steelman et al., 2004). Postulando-se que a hiperexpressão da proteína SHOC2 pode ativar a complexo Ras/Raf e 
consequentemente desencadear a ativação do efetor ERK, decidiu-se verificar o mecanismo pelo qual a SHOC2 pode induzir a sensibilidade das células leucêmicas ao quimioterápico. Para elucidar essa hipótese, realizou-se o silenciamento do gene SHOC2 (knockdown que representou um silenciamento de $83 \%$ da expressão e a completa ausência da expressão protéica) em linhagem de células leucêmicas, com o intuito de avaliar a sua função.

Uma vez realizado o silenciamento gênico, realizou-se dois tipos de ensaios funcionais sendo eles os ensaios de proliferação e viabilidade celular e ensaios de indução de apoptose. Os dados encontrados mostram que na ausência da proteína SHOC2 houve uma inibição da proliferação celular em comparação às células não silenciadas, indicando que a presença de SHOC2 pode desempenhar um papel importante no processo de proliferação celular, atuando como regulador positivo na ativação de ERK, a qual pode inibir os efeitos antiproliferativos de fatores como o TGF $\beta$ (transforming growth factor beta) (Fong et al., 2006). Consequentemente, pode-se sugerir que a provável indução da proliferação celular pela proteína SHOC2 pode levar ao aumento da sensibilidade às drogas quimioterápicas. Essa hipótese pode ser explicada pelo fato de que a daunorrubicina, quimioterápico o qual o SHOC2 foi inicialmente associado, é um inibidor de topoisomerase II ciclo celular específico, o que indica que níveis elevados de proliferação poderiam tornar as células leucêmicas mais susceptíveis à ação dos quimioterápicos (Hait; Hambley, 2009).

Existe, no entanto, outra possibilidade plausível para explicar a redução da proliferação celular ocasionada pelo silenciamento da Shoc2, como por 
exemplo, a potencialização da atividade de outras proteínas que poderiam se favorecer deste silenciamento. Dentre essas, a proteína Erbin, que é uma proteína rica em repetições de leucina e faz parte da família de proteínas LAP (LRR and $\underline{\text { PDZ - }}$ “leucine-rich repeats and PDZ protein family). Segundo Huang e colaboradores (2003), a proteína Erbin, além de regular a ativação de receptores de neurorregulina (como a ERBB2), atua como um regulador negativo da via Ras/Raf/Erk, por meio da inativação de Erk, mediada por Ras. Essa inativação ocorre por meio da ruptura do complexo formado por Ras/Raf/Shoc2, caracterizando a competição entre Shoc2 e Erbin pela ligação à molécula de Ras ativada. Essa competição pode ser explicada pelo fato de ambas apresentarem um domínio LRR o qual possui afinidade pela ligação ao RAS ativado. (Dai et al., 2006).

Por outro lado, quando realizamos o ensaio de indução de apoptose, observou-se uma redução no número de células apoptóticas dentre as células silenciadas em relação às não silenciadas. Os resultados demonstram ainda um índice elevado de células viáveis dentre as células silenciadas em comparação aos controles, mostrando que a ausência da proteína SHOC2 pode estar associada à redução da apoptose. Sendo assim, pode-se sugerir ainda que, a proteína SHOC2 possui uma participação importante no processo de indução de apoptose, que seria mediado pela ativação de Erk, que consequentemente pode levar à fosforilação de moléculas reguladoras da apoptose. Essa hipótese reafirma a possível participação da proteína Shoc2 no processo de sensibilidade das células leucêmicas ao tratamento o que possibilita a melhor sobrevida dos pacientes. Esse fato contribuiu para reafirmar a hipótese que sugere que o equilíbrio entre os processos de proliferação 
celular e de indução de apoptose podem ser a chave para o sucesso dos tratamentos quimioterápicos, além de sugerir a proteína SHOC2 como um importante alvo terapêutico.

\subsection{CONSIDERAÇÕES FINAIS}

Embora atualmente o tratamento da LLA consiga atingir índices bastante elevados de cura, o insucesso representado pela faixa de pacientes que ainda são resistentes ao tratamento permanece, e uma das causas mais importantes dessa falha não somente das leucemias agudas em crianças, mas também relacionados com as neoplasias em geral, é a resistência intrínseca ou adquirida aos quimioterápicos. Por outro lado, existe também um subgrupo de pacientes que são muito sensíveis à terapia, demonstrando que o tratamento intensivo pode ter efeitos significativos por um longo período, incluindo a emergência de malignidades secundárias e de déficits no desenvolvimento.

O entendimento de mecanismos biológicos que levam os pacientes com LLA à recaída e a identificação de marcadores de resposta é um passo crítico para o desenvolvimento de estratégias alternativas para o tratamento de pacientes resistentes à terapia e tem sido exaustivamente investigado. No entanto, o conhecimento disponível dos mecanismos moleculares que levam à resistência ainda são incompreendidos e altamente conflitantes. Estudos recentes baseados em expressão gênica têm identificado diversos prováveis marcadores de resposta, entretanto, o entendimento da patogênese molecular do câncer, ainda requer o exato conhecimento das alterações genéticas que acometem uma célula tumoral. 
O presente trabalho identificou diversos genes associados à resistência individual às drogas e que poderiam representar importantes marcadores. Dentre eles se destacou o gene $S H O C 2$, o qual apresentou dados interessantes em relação à resposta favorável ao tratamento quimioterápico em LLA da infância, sugerindo um novo alvo de estudos para a comprovação da sua real importância. Os resultados, embora necessitem de estudos subseqüentes, demonstram que a investigação da patogênese molecular da leucemia pode contribui imensamente para o desenvolvimento de terapias moleculares alternativas que possam aprimorar os efeitos antileucêmicos do tratamento quimioterápico. 
Conctusões 


\section{CONCLUSÕES}

1. Os genes envolvidos com o mecanismo de resistência aos quimioterápicos vincristina, daunorrubicina, prednisona e L-asparaginase apresentaram uma expressão altamente variável entre as amostras de pacientes com LLA (tratadas pelo protocolo do GBTLI) ao diagnóstico.

2. Os genes GPR56, BLVRB e IGFBP7 apresentaram-se correlacionados com o número de glóbulos brancos ao diagnóstico.

3. Os genes CD44, MAP3K12, KCNN1, MAN1A1, GATA3 e SHOC2 apresentaram-se associados com o antígeno CD10 (CALLA).

4. Os genes TCFL4, KCNN1, TRIM24, PDCH9 e CD69 foram associados com a presença de doença residual mínima.

5. A presença de medula M1 no $28^{\circ}$ dia esteve associada com a expressão dos genes MAP3K12 e TRIM24.

6. A presença da translocação TELA/ML1 esteve associada com os genes TCFL5, KCNN1 e TRIM24.

7. Na análise de sobrevida livre de evento em 5 anos, a hiperexpressão do gene SHOC2 esteve associada com a sobrevida elevada dos pacientes.

8. Na análise dos pacientes submetidos ao protocolo do BFM, observou-se uma associação entre a hiperexpressão do gene SHOC2 entre os pacientes de risco básico e que apresentaram boa resposta ao tratamento. 
9. Na análise do gene GPR56 nos pacientes submetidos ao protocolo BFM, não houve diferença significativa entre os grupos estudados.

10. A análise protéica do gene $S H O C 2$ confirmou os dados de hipo e hiperexpressão obtidos na análise por RQ-PCR.

11. O silenciamento do gene $S H O C 2$ reduziu significativamente a proliferação das células leucêmicas Jurkat.

12. A redução da expressão gênica causada pelo silenciamento do gene SHOC2 foi capaz de inibir a indução de apoptose. 
Referências Bibliográficas 


\section{REFERÊNCIAS BIBLIOGRÁFICAS}

Adamson E, de Belle I, Mittal S, Wang Y, Hayakawa J, Korkmaz K, O'Hagan D, mcclelland M, Mercola D. Egr1 signaling in prostate cancer. Cancer Biol Ther. 2003 Nov-Dec;2(6):617-22. Review.

Adelman AS, Groves FD, O'Rourke K, Sinha D, Hulsey TC, Lawson AB, Wartenberg D, Hoel DG. Residential mobility and risk of childhood acute lymphoblastic leukaemia: an ecological study. Br J Cancer. 2007 Jul 2;97(1):140-4. Epub 2007 May 29.

Ahola, TM; Alkio, N., Manninen T., Ylikomi, T. Progestin and G protein-coupled receptor 30 inhibit mitogen-activated protein kinase activity in MCF-7 breast cancer cells, Endocrinology. 2002; 143: 4620-4626.

Altorjay A, Paal B, Sohar N, Kiss J, Szanto I, Sohar I. Significance and prognostic value of lysosomal enzyme activities measured in surgically operated adenocarcinomas of the gastroesophageal junction and squamous cell carcinomas of the lower third of esophagus. World J Gastroenterol. 2005; Oct 7;11(37):5751-6.

Arai M, Yoguchi A, Takizawa T, Yokoyama T, Kanda T, Kurabayashi M, Nagai R. Mechanism of doxorubicin-induced inhibition of sarcoplasmic reticulum $\mathrm{Ca}(2+)$-atpase gene transcription. Circ Res. 2000 Jan 7-21;86(1):8-14.

Arico, M. Cytoreduction and prognosis in childhood acute lymphoblastic leukemia. J. Clin. Oncol. 1997; 15: 1285 (letter).

Arico, M., Basso, G., Mandelli, F., Rizzari, C., Colella, R., Barisone, E., Zanesco, L., Rondelli, R., Pession, A. And Masera, G. Good steroid response in vivo predicts a favorable outcome in children with T-cell acute lymphoblastic leukemia. The Associazione Italiana Ematologia Oncologia Pediatrica (AIEOP). Cancer, (1995). 75: 1684-1693.

Beillard E, Pallisgaard N, van der Velden VHJ, Bi W, Dee R, van der Schoot E et al. Evaluation of candidate control genes for diagnosis and residual disease detection in leukemic patients using 'real-time' quantitative reverse-transcriptase polymerase chain reaction (RQ-PCR) - a Europe against cancer program. Leukemia 2003; 17:2474-2486.

Bourguignon LY, Zhu D, Zhu H. CD44 isoform-cytoskeleton interaction in oncogenic signaling and tumor progression. Front Biosci. 1998 Jul 1;3:d637-49. Review. 
Brandalise, S.R. Odone, V., Pereira W.V. et al.. Teatment results of three Consecutive Brazilian Cooperative Childhood ALL Protocols: GBTLI 80 - 82 and 85. Leukemia, 1993; 7(2) : $142-145$.

Brown JM, Wouters BG. Apoptosis, p53, and tumor cell sensitivity to anticancer agents. Cancer Res. 1999; Apr 1;59(7):1391-9.

Brozek, Jacek; Bryl, Ewa; Ploszynska, Anna; Balcerska, Anna; Witkowski, Jacek M. Pglycoprotein Activity Predicts Outcome in Childhood Acute Lymphoblastic Leukemia J Pediatric Hematology/Oncology: July 2009; Volume 31 - Issue 7 - pp 493-499

Brusa G, Zuffa E, Hattinger CM, Serra M, Remondini D, Castellani G, Righi S, Campidelli C, Pileri S, Zinzani PL, Gabriele A, Mancini M, Corrado P, Barbieri E, Santucci MA. Genomic imbalances associated with secondary acute leukemias in Hodgkin lymphoma. Oncol Rep. 2007; Dec;18(6):1427-34.

Campana D. Molecular determinants of treatment response in acute lymphoblastic leukemia. Hematology Am Soc Hematol Educ Program. 2008:366-73.

Carroll WL, Bhojwani D, Min DJ, Raetz E, Relling M, Davies S, Downing JR, Willman CL, Reed JC. Pediatric acute lymphoblastic leukemia. Hematology (Am Soc Hematol Educ Program). 2003; 102-31.

Chang L, Karin M. Mammalian MAP kinase signaling cascades. Nature. 2001;410:37-40.

Chen MW, Vacherot F, De La Taille A, Gil-Diez-De-Medina S, Shen R, Friedman RA, Burchardt M, Chopin DK, Buttyan R. The emergence of protocadherin-PC expression during the acquisition of apoptosis-resistance by prostate cancer cells. Oncogene. 2002 Nov 7;21(51):7861-71.

Cho D, Kim YI, Kang JS, Hahm E, Yang Y, Kim D, Kim S, Kim YS, Hur D, Park H, Hwang YI, Kim TS, Lee WJ. Resistance to cytotoxic chemotherapy is induced by NK cells in nonHodgkin's Lymphoma Cells. J Clin Immunol. 2004 Sep;24(5):553-60.

Choi MG, Sohn TS, Park SB, Paik YH, Noh JH, Kim KM, Park CK, Kim S. Decreased expression of $\mathrm{p} 12$ is associated with more advanced tumor invasion in human gastric cancer tissues. Eur Surg Res. 2009;42(4):223-9. Epub 2009 Mar 12.

Dai P, Xiong WC, Mei L. Erbin inhibits RAF activation by disrupting the sur-8-Ras-Raf complex. J Biol Chem. 2006; Jan 13;281(2):927-33. Epub 2005 Nov 21. 
Daniel, P. F., Winchester, B. and Warren, C. D. Mammalian a-mannosidases-multiple forms but a common purpose? Glycobiology. 1994; 4: 551-566

Derek S. Sieburth, Qun Sun, and Min Han* SUR-8, a Conserved Ras-Binding Protein with Leucine-Rich Repeats, Positively Regulates Ras-Mediated Signaling in C. elegans Cell. 1998;Vol. 94, 119-130.

Di Tullio, M.T., D’Angelo, V.D., Casale, F. et al.. Glucocorticoid-induced apoptosis in 20 children with acute lymphoblastic leukemia. Proc. Int. Soc. Ped. Oncol. In Med. Ped. Oncol. 1998; 31 (4): 269 (abstr. P-46).

Dordelmann, M., Reiter, A., Borkhardt, A., Ludwig, W.D., Gotz, N., Viehmann, S., Gadner, H., Riehm, H. And Schrappe, M.. Prednisone response is the strongest predictor of treatment outcome in infant acute lymphoblastic leukemia. Blood. 1999; 94: 1209-17.

Evans, W.E., Relling, M.V., Rodman, J.H., Crom, W.R., Boyett, J.M. and Pui, C.-H. Conventional compared with individualized chemotherapy for childhood acute lymphoblastic leukemia. N. Engl. J. Med. 1998; 338: 499-.

Fay PJ. Factor VIII Structure and Function. Int J Hematol. 2006; 83(2):103-8.

Fong CW, Chua MS, McKie AB, Ling SH, Mason V, Li R et al. Sprouty 2, an inhibitor of mitogen-activated protein kinase signaling, is down-regulated in hepatocellular carcinoma. Cancer Res. 2006; 66: 2048-2058.

Ford AM, Pombo-de-Oliveira MS, McCarthy KP, MacLean JM, Carrico KC, Vincent RF, Greaves M. Monoclonal origin of concordant T-cell malignancy in identical twins. Blood. 1997; Jan 1;89(1):281-5.

Gandini D, De Angeli C, Aguiari G, Manzati E, Lanza F, Pandolfi PP, Cuneo A, Castoldi GL, del Senno L. Preferential expression of the transcription coactivator HTIF1alpha gene in acute myeloid leukemia and MDS-related AML. Leukemia. 2002 May;16(5):886-93.

Garami, M., Bocsi, J., Kovacs, G. Et al.. Apoptotic ratio as an early prognostic factor in acute lymphoblastic leukemia in children. Proc. Int. Soc. Ped. Oncol. In Med. Ped. Oncol. 1999; 33 (3): 269 (abstr. P-344).

Gaynon, P.S., Desai, A.A., Bostrom, B.C., Hutchinson, R.J., Lange, B.J., Nachman, J.B., Reaman, G.H., Sather, H.N., Steinherz, P.G., Trigg, M.E., Tubergen, D.G. and Uckun, F.M.. Early response to therapy and outcome in childhood acute lymphoblastic leukemia: a review. Cancer. 1997; 80: 1717-1726. 
Grupo Brasileiro de Tratamento da Leucemia Infantil. GBTLI LLA-99 - protocolo de tratamento da leucemia linfóide aguda em crianças. Campinas: [s.n]; 2000.188p.

Greaves M. Childhood Leukemia. BMJ. 2002; 324:283-7. Review.

Greaves M. Molecular genetics, natural history and the demise of childhood leukaemia. Eur J Cancer. 1999; Dec;35(14):1941-53.

Greaves, M.F. Aetiology of acute leukemia. Lancet. 1997; 349: 344-349.

Gunz, F.W. Leukemia in the past. In: Henderson, E.S.; Lister, T.A. (eds) William Dameshek and Frederick Gunz's leukemia. 5ed. Philadelphia, P.A.: WB Saunders Company, 1990:3-11.

Gustafsson G, Lie SO. Acute leukaemias. In: Voûte PA, Kalifa C, Barrett A, Cancer in children, $4^{\text {th }}$ ed. Oxford, Oxford University Press; 1998. p99-118.

Gutkind JS. Regulation of mitogen-activated protein kinase signaling networks by G proteincoupled receptors. Sci STKE. 2000 Jul 11;2000(40):re1.

Hait WN, Hambley TW. Targeted cancer therapeutics. Cancer Res. 2009; Feb 15;69(4):1263-7.

Hantschel O, Gstoettenbauer A, Colinge J, Kaupe I, Bilban M, Burkard TR, Valent P, SupertiFurga G. The chemokine interleukin-8 and the surface activation protein CD69 are markers for Bcr-Abl activity in chronic myeloid leukemia. Mol Oncol. 2008 Oct;2(3):272-81. Epub 2008 Jul 23.

Harris, M.B., Shuster, J.J., Pullen, J., et al. Consolidation therapy with anti-metabolite based therapy in standard risk acute lymphocytic leukemia of childhood: A Pediatric Oncology Group Study. J. Clin. Oncol. 1998; 16 (8): 2840-2847.

Hiraoka A, Yano Ki K, Kagami N, Takeshige K, Mio H, Anazawa H, Sugimoto S. Stem cell growth factor: in situ hybridization analysis on the gene expression, molecular characterization and in vitro proliferative activity of a recombinant preparation on primitive hematopoietic progenitor cells. Hematol J. 2001;2(5):307-15.

Hiraoka A. Leukemia cell lines require self-secreted stem cell growth factor (SCGF) for their proliferation. Leuk Res. 2008; Oct;32(10):1623-5. Epub 2008 Mar 4.

Hiyoshi Y, Watanabe M, Hirashima K, Karashima R, Sato N, Imamura Y, Nagai Y, Yoshida $\mathrm{N}$, Toyama E, Hayashi N, Baba H. p12CDK2-AP1 is associated with tumor progression and a poor prognosis in esophageal squamous cell carcinoma. Oncol Rep. 2009 Jul;22(1):35-9. 
Ho, I.C., et al. Human GATA-3: a lineage-restricted transcription factor that regulates the expression of the T cell receptor alpha gene. EMBO J. 1991; 10:1187-1192.

Hoffman, J. F., Joiner, W., Nehrke, K., Potapova, O., Foye, K. And Wickrema, A., The hsk4 (KCNN4) isoformis the Ca2+-activated $\mathrm{K}+$ channel (Gardos channel) in human red blood cells. Proc. Natl. Acad. Sci. USA 2003; 100: 7366-7371.

Hoey, RP, Sanderson, C., Iddon, J., Brady, G., Bundred, NJ., Anderson,NJ. The parathyroid hormone-related protein receptor is expressed in breast cancer bone metastases and promotes autocrine proliferation in breast carcinoma cells, Br. J. Cancer. 2003; 88: 567-573.

Holleman A, Cheok MH, den Boer ML, Yang W, Veerman AJ, Kazemier KM, Pei D, Cheng C, Pui CH, Relling MV, Janka-Schaub GE, Pieters R, and Evans WE. Gene-expression patterns in drug-resistant acute lymphoblastic leukemia cells and response to treatment. $\mathrm{N}$ Engl J Med. 2004; 351(6):533-542.

Hu MG, Hu GF, Kim Y, Tsuji T, mcbride J, Hinds P, Wong DT. Role of p12(CDK2-AP1) in ransforming growth factor-beta1-mediated growth suppression. Cancer Res. 2004; Jan 15;64(2):490-9.

Huang YZ, Zang M, Xiong WC, Luo Z, Mei L. Erbin suppresses the MAP kinase pathway. J Biol Chem. 2003; Jan 10;278(2):1108-14.

Ikeguchi,M., Hirooka, Y., Kaibara, N. Quantitative reverse transcriptase polymerase chain reaction analysis for KiSS-1 and orphan G-protein-coupled receptor (hOT7T175) gene expression in hepatocellular carcinoma, J. Can. Res. Clin. Oncol. 129 (2003) 531-535.

Jensen, B. S., Strobaek, D., Olesen, S. P. And Christophersen, P., The Ca2+-activated K+ channel of intermediate conductance: a molecular target for novel treatments? Curr. Drug Targets 2001. 2: 401-422.

Jothy S. CD44 and its partners in metastasis. Clin Exp Metastasis. 2003;20(3):195-201. Review.

Kato, M.V. A secreted tumor-suppressor, mac25, with activin-binding activity. Mol. Med. 2000; 6(2):126-135.

Kaspers GJ, Veerman AJ. Clinical significance of cellular drug resistance in childhood leukemia. Recent Results Cancer Res. 2003; 161:196-220.

Kaspers, G.J., Veerman, A.J., Pieters, R. Et al. (1997). In vitro cellular drug resistance and prognosis in newly diagnosed childhood acute lymphoblastic leukemia. Blood 90: 2723-. 
Kebriaei P, Larson RA. Progress and challenges in the therapy of adult acute lymphoblastic leukemia. Curr Opin Hematol. 2003;10(4):284-9.

Kincade PW, Zheng Z, Katoh S, Hanson L. The importance of cellular environment to function of the CD44 matrix receptor. Curr Opin Cell Biol. 1997 Oct;9(5):635-42. Review.

Komatsu, S., Okazaki, Y., Tateno, M., Kawai, J., Konno, H., Kusakabe, M., Yoshiki, A., Muramatsu, M., Held, W.A., Hayashizaki, Y., 2000. Methylation and downregulated expression of mac25/insulin-like growth factor binding protein-7 is associated with liver tumorigenesis in SV40T/t antigen transgenic mice, screened by restriction landmark genomic scanning for methylation (RLGS-M). Biochem. Biophys. Res. Commun., 267(1):109117.

Komuro A, Tobe T, Nakano Y, Yamaguchi T, Tomita M. Cloning and characterization of the cdna encoding human biliverdin-IX alpha reductase. Biochim Biophys Acta. 1996 Nov 11;1309(1-2):89-99.

Kotilo, P. N. Flow citometric analysis in diagnostic hematology. In: RODAK, B. F. Diagnostic hematology. Sunders Company, 1995.

Künzli BM, Berberat PO, Giese T, Csizmadia E, Kaczmarek E, Baker C, Halaceli I, Büchler MW, Friess H, Robson SC. Upregulation of CD39/NTPDases and P2 receptors in human pancreatic disease. Am J Physiol Gastrointest Liver Physiol. 2007 Jan;292(1):G223-30. Epub 2006 Aug 17.

Lesley J, Hyman R, Kincade PW. CD44 and its interaction with extracellular matrix. Adv Immunol. 1993;54:271-335. Review.

Levine RL. Inherited susceptibility to pediatric acute lymphoblastic leukemiaNat Genet. 2009 Sep;41(9):957-8.

Li, W., Han, M., and Guan, K.L. (2000). The leucine-rich repeat protein SUR-8 enhances MAP kinase activation and forms a complex with Ras and Raf. Genes Dev. 14, 895-900.

Lightfoot T. Aetiology of childhood leukemia. Bioelectromagnetics. Suppl 7:S5-S11, 2005.

Litt M, LaMorticella D, Bond CT, Adelman JP. Gene structure and chromosome mapping of the human small-conductance calcium-activated potassium channel SK1 gene (KCNN1). Cytogenet Cell Genet. 1999;86(1):70-3. 
Liu M, Parker RM, Darby K, Eyre HJ, Copeland NG, Crawford J, Gilbert DJ, Sutherland GR, Jenkins NA, Herzog H. GPR56, a novel secretin-like human G-protein-coupled receptor gene. Genomics. 1999; Feb 1;55(3):296-305.

Livak K, Schmittgen T. Analysis of relative gene expression data using real-time quantitative PCR and the 2- $\triangle \triangle \mathrm{Ct}$ method. Methods 2001; 25:402-408.

Maines MD, Mayer RD, Erturk E, Huang TJ, Disantagnese A. The oxidoreductase, biliverdin reductase, is induced in human renal carcinoma--ph and cofactor-specific increase in activity. J Urol. 1999 Oct;162(4):1467-72.

Malempati S, Gaynon PS, Sather H, La MK, Stork LC; Children's Oncology Group. Outcome after relapse among children with standard-risk acute lymphoblastic leukemia: Children's Oncology Group study CCG-1952. . J Clin Oncol. 2007 Dec 20;25(36):5800-7.

Margolin JF, Steuber CP, Poplack DG. Acute lymphoblastic leukemia. In: Pizzo PA, Poplack DG, Principles and practice of pediatric oncology, $4^{\text {th }}$ ed. Philadelphia, Lippincott Williams \& Wilkins; 2002. p 498-544.

Margolin JF; Poplack DG. Acute lymphoblastic leukemia. In: Pizzo PA, Poplack, DG (eds). Principles and Pratices of Pediatric Oncology. 3. Ed. Philadelphia JB Lippincott Company, Chapter 17, p. 409-462, 1997.

Marzio R, Mauel J, Betz-Corradin S. CD69 and regulation of the immune function. Immunopharmacol Immunotoxicol. 1999 Aug;21(3):565-82. Review.

Matsuo, K., Shintani, S., Tsuji, T., Nagata, E., Lerman, M., mcbride, J., Nakahara, Y., Hyama, H., Todd, R., and Wong, D. T. P12(DOC-1), a growth suppressor, associates with DNA polymerase _/primase. FASEB J. 2000; 14: 1318-1324.

Michieli M, Damiani D, Ermacora A, Geromin A, Michelutti A, Masolini P, Baccarani M. Pglycoprotein (PGP), lung resistance-related protein (LRP) and multidrug resistanceassociated protein (MRP) expression in acute promyelocytic leukaemia. Br J Haematol.2000; 108(4):703-9.

Milella M, Kornblau SM, Andreeff M. Mitogen-activated protein kinases in apoptosis regulation. Oncogene. 2004 Apr 12;23(16):2838-49. Review.

Mrózek K, Harper DP, Aplan PD. Cytogenetics and molecular genetics of acute lymphoblastic leukemia. Hematol Oncol Clin North Am. 2009; Oct;23(5):991-1010, v. 
Murphy, M., Pykett, M.J., Harnish, P., Zang, K.D., George, D.L. Identification and characterization of genes differentially expressed in meningiomas. Cell Growth Differ. 1993; $4(9): 715-722$.

Mutaguchi, K., Yasumoto, H., Mita, K., Matsubara, A., Shiina, H., Igawa, M., Dahiya, R., Usui, T., 2003. Restoration of insulin-like growth factor binding protein-related protein 1 has a tumor-suppressive activity through induction of apoptosis in human prostate cancer. Cancer Res., 63(22):7717-7723.

Nachman JB, Heerema NA, Sather H, Camitta B, Forestier E, Harrison CJ, Dastugue N, Schrappe M, Pui CH, Basso G, Silverman LB, Janka-Schaub GE. Outcome of treatment in children with hypodiploid acute lymphoblastic leukemiaBlood. 2007 Aug 15;110(4):1112-5. Epub 2007 May 1.

Naor D, Sionov RV, Ish-Shalom D. CD44: structure, function, and association with the malignant process. Adv Cancer Res. 1997;71:241-319. Review.

Panzer-Grümayer, E.R., Fasching, K. , Stolz, F, Cazzaniga, G. Et al. (1999). Prognostic Value of Blasts on Day 15 in Bone Marrow and of Molecular evaluation of remission in children with Acute Lymphoblastic Leukemia. Proc. Int. Soc. Oncol. In Med. Ped. Oncol., 33 (3) :159 (abstract 0 - 64).

Pereira PJ, Macedo-Ribeiro S, Parraga A, Perez-Luque R, Cunningham O, Darcy K, Mantle TJ, Coll M. Structure of human biliverdin ixbeta reductase, an early fetal bilirubin ixbeta producing enzyme. Nat Struct Biol. 2001 Mar;8(3):215-20.

Piao X, Hill RS, Bodell A, Chang BS, Basel-Vanagaite L, Straussberg R, Dobyns WB, Qasrawi B, Winter RM, Innes AM, Voit T, Ross ME, Michaud JL, Déscarie JC, Barkovich AJ, Walsh CA. G protein-coupled receptor-dependent development of human frontal cortex. Science. 2004; Mar 26;303(5666):2033-6.

Pieters, R., Kaspers, G.J.L., Klumper, E. et al. Clinical relevance of in vitro drug resistance testing in childhood acute lymphoblastic leukemia: The state of the art. Med. Pediatr. Oncol. 1994; 22: 299-308.

Pileri S.A., Ascani S., Milani, M. Acute leukemia immnunophenotyping in bone-marrow routine sections. British Journal of Hematology. 1999; 105:394-401.

Pinkel D. Fiveýear follow up of "total therapy" of childhood acute lymphocytic leukemia. JAMA, v. 216, p. 648-652, 1971.

Privitera E, Kamps MP, Hayashi Y, Inaba T, Shapiro LH, Raimondi SC, Behm F, Hendershot L, Carroll AJ, Baltimore D, et al. Different molecular consequences of the 1;19 chromosomal 
translocation in childhood B-cell precursor acute lymphoblastic leukemia. Blood. 1992 Apr 1;79(7):1781-8.

Pui CH, Evans WE. Treatment of acute lymphoblastic leukemia. N Engl J Med. 2006 Jan 12;354(2):166-78.

Pui CH, Schrappe M, Ribeiro RC, Niemeyer CM. Childhood and adolescent lymphoid and myeloid leukemia. Hematology (Am Soc Hematol Educ Program).118-45, 2004.

Pui $\mathrm{CH}$, Thiel E. Central nervous system disease in hematologic malignancies: historical perspective and practical applications. Semin Oncol. 2009 Aug;36(4 Suppl 2):S2-S16.

Pui CH. Childhood leukemias. New Engl. J. Med. 332: 1618-1630, 1995.

Pui CH. Update on Pediatric ALL. Clin Adv Hematol Oncol. 2006; 4(12):884-6.

Pui CH. Acute lymphoblastic leukemia: introduction. Semin Hematol. 2009 Jan;46(1):1-2.

Pui, C.-H. And Evans, W.E. (1998). Acute lymphoblastic leukemia. N. Engl. J. Med., 339 (9): 605-615.

Pui, C.H.; Behm, F.G.; Crist, W.M. Clinical and biological relevance of immunologic marker studies in childhood acute lymphoblastic leukeimia. Blood. 1993; v. 82, p. 343-362.

Raynaud S, Mauvieux L, Cayuela JM, Bastard C, Bilhou-Nabera C, Debuire B, Bories D, Boucheix C, Charrin C, Fière D, Gabert J. TEL/AML1 fusion gene is a rare event in adult acute lymphoblastic leukemia. Leukemia. 1996; Sep;10(9):1529-30.

Relling MV, Rubnitz JE, Rivera GK, Boyett JM, Hancock ML, Felix CA, Kun LE, Walter AW, Evans WE, Pui $\mathrm{CH}$. High incidence of secondary brain tumours after radiotherapy and antimetabolites. Lancet. V. 3;354(9172):34-9, 1999.

Rice AM, Holtz KM, Karp J, Rollins S, Sartorelli AC. Analysis of the relationship between Scl transcription factor complex protein expression patterns and the effects of $\mathrm{LiCl}$ on ATRAinduced differentiation in blast cells from patients with acute myeloid leukemia. Leuk Res. 2004; Nov;28(11):1227-37.

Robinson MJ, Cobb MH. Mitogen-activated protein kinase pathways. Curr Opin Cell Biol. 1997 Apr;9(2):180-6. 
Rodríguez CI, Gironès N, Fresno M. Cha, a basic helix-loop-helix transcription factor involved in the regulation of upstream stimulatory factor activity. J Biol Chem. 2003 Oct 31;278(44):43135-45. Epub 2003 Aug 15.

Rodriguez-Viciana P, Oses-Prieto J, Burlingame A, Fried M, McCormick F. A phosphatase holoenzyme comprised of Shoc2/Sur8 and the catalytic subunit of PP1 functions as an MRas effector to modulate Raf activity. Mol Cell. 2006 Apr 21;22(2):217-30.

Saito F, Yamaguchi T, Komuro A, Tobe T, Ikeuchi T, Tomita M, Nakajima H. Mapping of the newly identified biliverdin-IX beta reductase gene (BLVRB) to human chromosome 19q13.13-->q13.2 by fluorescence in situ hybridization. Cytogenet Cell Genet. 1995;71(2):17981.

Sauerbrey A, Voigt A, Wittig S, Hafer R, Zintl F (2002). Messenger RNA analysis of the multidrug resistance related protein (MRP1) and the lung resistance protein (LRP) in de novo and relapsed childhood acute lymphoblastic leukemia. Leuk Lymphoma. 43(4):875-9.

Schrappe, M., Arico, M., Harbott, J., Biondi, A., Zimmermann, M., Conter, V., Reiter, A., Valsecchi, M.G., Gadner, H., Basso, G., Bartram, C.R., Lampert, F., Riehm, H. And Masera, G. Philadelphia chromosome-positive $(\mathrm{Ph}+)$ childhood acute lymphoblastic leukemia: good initial steroid response allows early prediction of a favorable treatment outcome. Blood. 1998; 92: 2730-2741.

Schrappe, M., Reiter, A. And Riehm, H. (1996). Cytoreduction and prognosis in childhood acute lymphoblastic leukemia. J. Clin. Oncol. 15: 2403-2405 (letter).

Scrideli CA, Assumpção JG, Ganazza MA, Araújo M, Toledo SR, Lee ML, Delbuono E, Petrilli AS, Queiróz RP, Biondi A, Viana MB, Yunes JA, Brandalise SR, Tone LG. A simplified minimal residual disease polymerase chain reaction method at early treatment points can stratify children with acute lymphoblastic leukemia into good and poor outcome groups. Haematologica. 2009 Jun;94(6):781-9.

Selfors LM, Schutzman JL, Borland CZ, Stern MJ. Soc-2 encodes a leucine-rich repeat protein implicated in fibroblast growth factor receptor signaling. Proc Natl Acad Sci U S A. 1998 Jun 9;95(12):6903-8.

Shintani S, Mihara M, Terakado N, Nakahara Y, Matsumura T, Kohno Y, Ohyama H, mcbride J, Kent R, Todd R, Tsuji T, Wong DT. Reduction of p12doc-1 expression is a negative prognostic indicator in patients with surgically resected oral squamous cell carcinoma. Clin Cancer Res. 2001 Sep;7(9):2776-82.

Smith MA, Ries LAG, Gurney JG, Ross JA. Leukemia. In: Ries LAG, Smith MA, Gurneu JG, Linet M, Tamra T, Young JL. Cancer incidence and survival among children and adolescents: United States SEER Program 1975-1995. NIH Pub No. 99-4649. Bethesda, 1999. p 17-34. 
Smith, M., Arthur, D., Camitta,B. et al. Uniform Approach to Risk Classification and Treatment Assignment for Children with acute lymphoblastic leukemia. J. Clin. Oncol. 1996;14(1):18-24.

Stasi R, Taylor CG, Venditti A, Del Poeta G, Aronica G, Bastianelli C, Simone MD, Buccisano $\mathrm{F}$, Cox MC, Bruno A, et al. Contribution of immunophenotypic and genotypic analyses to the diagnosis of acute leukemia. Ann Hematol. 1995; Jul;71(1):13-27.

Steelman LS, Pohnert SC, Shelton JG, Franklin RA, Bertrand FE, McCubrey JA. JAK/STAT, Raf/MEK/ERK, PI3K/Akt and BCR-ABL in cell cycle progression and leukemogenesis. Leukemia. 2004 Feb;18(2):189-218.

Steinherz ,P.G., Gaynon, P.S., Breneman, J. et al. Cytoreduction and prognosis in acute lymphoblastic leukemia - The importance of early marrow response : Report from the Childrens Cancer Group. J. Clin. Oncol. 1996a ; 14(2) : 389 - 398.

Steinherz, P.G., Gaynon, P., Trigg, M., Sather, H. and Bleyer, A.W. (1996b). In reply to "Cytoreduction and prognosis in childhood acute lymphoblastic leukemia". J. Clin. Oncol.1996b; 15: 2405-2406 (letter).

Stocker JW, De Franceschi L, mcnaughton-Smith GA, Corrocher R, Beuzard Y, Brugnara C ICA-17043, a novel Gardos channel blocker, prevents sickled red blood cell dehydration in vitro and in vivo in SAD mice. Blood. 2003 Mar 15;101(6):2412-8. Epub 2002 Nov 14.

Strehl S, Glatt K, Liu QM, Glatt H, Lalande M. Characterization of two novel protocadherins (PCDH8 and PCDH9) localized on human chromosome 13 and mouse chromosome 14. Genomics. 1998; 1;53(1):81-9.

Taub JW, Konrad MA, Ge Y, Naber JM, Scott JS, Matherly LH, Ravindranath Y. High frequency of leukemic clones in newborn screening blood samples of children with Bprecursor acute lymphoblastic leukemia. Blood. 2002; Apr 15;99(8):2992-6.

Terskikh, A.V., Easterday, M.C., Li, L., Hood, L., Kornblum, H.I., Geschwind, D.H. and Weissman, I.L. From hematopoiesis to neuropoiesis: evidence of overlapping genetic programs. Proc. Natl Acad. Sci. USA. 2001; 98, 7934-7939.

Todd, R., Mcbride, J., Tsuji, T., Donoff, R. B., Nagai, M., Chou, M. Y., Chiang, T., and Wong, D. T. Deleted in oral cancer-1 (doc-1), a novel oral tumor suppressor gene. FASEB J., 1995; 9: 1362-1370.

Toole, J. J., Knopf, J. L., Wozney, J. M., Sultzman, L. A., Buecker, J. L., Pittman, D. D., Kaufman, R. J., Brown, E., Shoemaker, C., Orr, E. C., Amphlett, G. W., Foster, W. B., Coe, M. L., Knutson, G. J., Fass, D. N., and Hewick, R. M. Nature. 1994; 312, 342-348. 
Tsangaris,G, Moscovi,M., Vrachnou,E. And Tzortzatou, S.F. (1996). Study of chemotherapyinduced apoptosis in peripheral blood of children with acute lymphoblastic leukemia. Proc. Int. Soc. Ped. Oncol. In Med. Ped. Oncol. 27(4) : 288 (abstr. P-5).

Underhill C. CD44: the hyaluronan receptor. J Cell Sci. 1992; Oct;103 ( Pt 2):293-8.

Van Der Kolk DM, Vries EGE, Muller M, Vallenga E. The role of drug efflux pumps in acute myeloid leukemia. Leuk Lymphoma. 2002; 43(4): 685-701.

Van der Velden VHJ, Hochhaus A, Cazzaniga G, Szczepanski T, Gabert J, van Dongen JJM. Detection of minimal residual disease in hematologic malignancies by real-time quantitative PCR: principles, approaches, and laboratory aspects. Leukemia 2003;17:1013-1034.

Van Dongen JJ, Macintyre EA, Gabert JA, Delabesse E, Rossi V, Saglio G, Gottardi E, Rambaldi A, Dotti G, Griesinger F, Parreira A, Gameiro P, Diaz MG, Malec M, Langerak AW, San Miguel JF, Biondi A. Standardized RT-PCR analysis of fusion gene transcripts from chromosome aberrations in acute leukemia for detection of minimal residual disease. Report of the BIOMED-1 Concerted Action: investigation of minimal residual disease in acute leukemia. Leukemia. 1999; 13(12):1901-1928.

Vassef M.A., Brynes R.K, Murata-Collins J.L et al. Surface immunoglobulin light chainpositive acute lymphoblastic leukemia os FAB L1 or L2 type: a report of 6 cases in adults. American Journal of Clinical Pathology. 1998; 110:143-149.

Watson, M.A., Gutmann, D.H., Peterson, K., Chicoine, M.R., Kleinschmidt-DeMasters, B.K., Brown, H.G., Perry, A. Molecular characterization of human meningiomas by gene expression profiling using high-density oligonucleotide microarrays. Am. J. Pathol. 2002; 161(2):665-672.

Whitby FG, Phillips JD, Hill CP, mccoubrey W, Maines MD. Crystal structure of a biliverdin IX alpha reductase enzyme-cofactor complex. J Mol Biol. 2002 Jun 21;319(5):1199-210.

Wiemels JL, Pagnamenta A, Taylor GM, Eden OB, Alexander FE, Greaves MF A lack of a functional $\mathrm{NAD}(\mathrm{P}) \mathrm{H}$ :quinone oxidoreductase allele is selectively associated with pediatric leukemias that have MLL fusions. Cancer Res. 1999; 59: 4095-4099.

Wilson, H.M., Birnbaum, R.S., Poot, M., Quinn, L.S., Swisshelm, K. Insulin-like growth factor binding protein- related protein 1 inhibits proliferation of MCF-7 breast cancer cells via a senescence-like mechanism. Cell Growth Differ. 2002; 13(5):205-213.

Xavier AC, Ge Y, Taub JW. Down syndrome and malignancies: a unique clinical relationship: a paper from the 2008 william beaumont hospital symposium on molecular pathology. J Mol Diagn. 2009 Sep;11(5):371-80. 
Xu L, Begum S, Hearn JD, Hynes RO. GPR56, an atypical G protein-coupled receptor, binds tissue transglutaminase, TG2, and inhibits melanoma tumor growth and metastasis. Proc Natl Acad Sci U S A. 2006 Jun 13;103(24):9023-8. Epub 2006 Jun 6.

Zolochevska O, Figueiredo ML. Cell cycle regulator cdk2ap1 inhibits prostate cancer cell growth and modifies androgen-responsive pathway function. Prostate. 2009; Oct 1;69(14):1586-97.

Zuna J, Burjanivova T, Mejstrikova E, Zemanova Z, Muzikova K, Meyer C, Horsley SW, Kearney L, Colman S, Ptoszkova H, Marschalek R, Hrusak O, Stary J, Greaves M, Trka J. Covert preleukemia driven by MLL gene fusion. Genes Chromosomes Cancer. 2009; Jan;48(1):98-107. 
Anexos 


\section{ANEXOS}

\section{ANEXO A}

Carta de Aprovação do Comitê de Ética em Pesquisa do HC-FMRP-USP

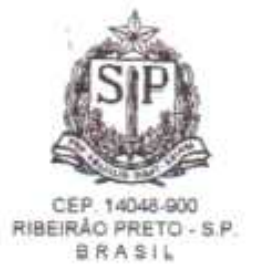

Oficio $\mathrm{n}^{\circ} 350 / 2002$

CEP/SPC

Senhor Professor:

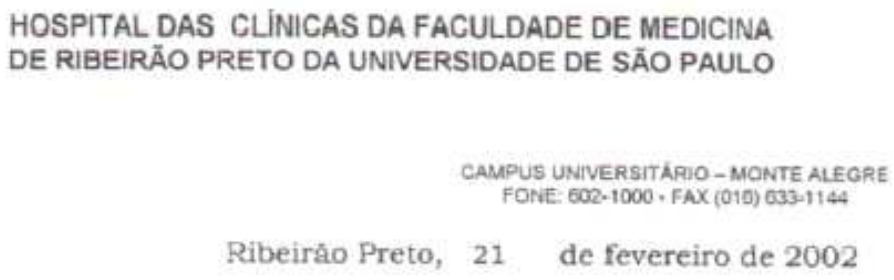

\section{O trabalho intitulado "PADRÃO DE}

EXPRESSÃO GÊNICA DA LEUCEMIA LINFOBLÁSTICA AGUDA DA CRIANÇA ASSOCIADA A RESISTENCIA A QUIMIOTERAPIA. (GENE EXPRESSION PROFILES ASSOCLATED WITH CHEMOTHERAPY REISTANCE IN ACUTE LYMPHOBLASTIC LEUKEMIA OF CHILHOOD)", foi analisado pelo Comitê de Ética em Pesquisa, em sua 124* Reuniāo Ordinária realizada em 18/02/2002, e enquadrado na categoria: APROVADO, bem como o Termo de Consentimento Livre e Esclarecido, de acordo com o Processo HCRP n $8681 / 2001$. Lembramos que devem ser encaminhados a este CEP relatórios semestrais e relatório final da pesquisa.

Entretanto, deve-se aguardar a manifestação da CONEP, pois o projeto será encaminhado para apreciação e aprovaçẫo. Vossa Senhoria protestos de estima e consideraçāo. Aproveito a oportunidade para apresentar a

Ilustrissimo Senhor PROF. DR. LUIZ GONZAGA TONE

Depto. de Puericultura e Pediatria 


\section{ANEXO B}

\section{Carta de Manifestação do CONEP}

MINISTERIO DA SALDE

Cansethw Naciunat de Sajur

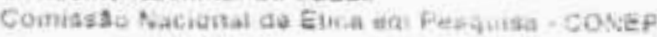

PARECER N 11542002

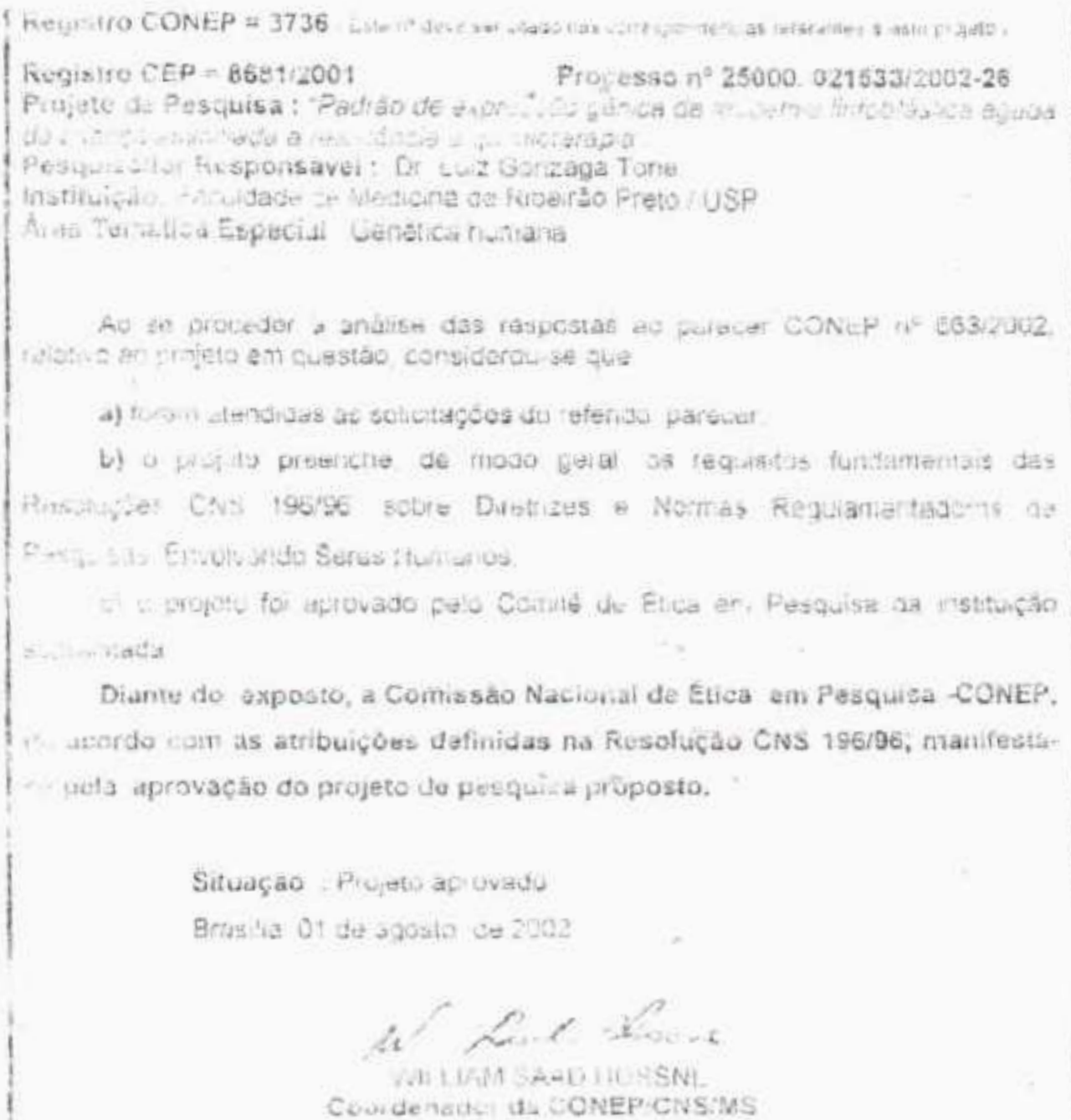

Diantu do soposto, a Comiasa Naciowal de Etica an Pesquiga CONEP.

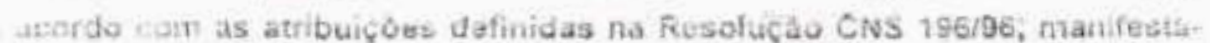
Hola apravaçào do projeto do pesquín proposto. 
Artigo submetido à Publicacão 


\section{Contributing genes to chemotherapy response in childhood acute lymphoblastic leukemia}

Vanessa da Silva Silveira, ${ }^{1}$ Carlos Alberto Scrideli, ${ }^{2}$ Daniel Antunes Moreno, ${ }^{1}$ José Andres Yunes, ${ }^{3}$ Rosane Gomes de Paula Queiroz, ${ }^{1}$ Silvia Regina Caminada Toledo, ${ }^{4}$ Priscila Pavoni-Ferreira, ${ }^{4}$ Maria Lúcia de Martino Lee, ${ }^{4}$ Antonio Sérgio Petrilli, ${ }^{4}$ Silvia Regina Brandalise, ${ }^{3,5}$ Luiz Gonzaga Tone ${ }^{1,2}$.

${ }^{1}$ Department of Genetics and ${ }^{2}$ Department of Pediatrics, Faculty of Medicine of Ribeirão Preto, University of São Paulo, Ribeirão Preto, SP, Brazil. ${ }^{3}$ Boldrini Institute, Campinas, SP, Brazil; ${ }^{4}$ Institute of Pediatric Oncology, Federal University of São Paulo, ${ }^{5}$ Campinas State University, Campinas, SP, Brazil.

Running Title: Gene expression in Acute Lymphoblastic Leukemia outcome

Corresponding author: Vanessa da Silva Silveira, Departamento de Genética, Faculdade de Medicina de Ribeirão Preto, Universidade de São Paulo, Avenida Bandeirantes 3900, 14048-900 Ribeirão Preto - SP, Brazil. Telephone: 5516 3602-2651; FAX: 5516 3602-2700. E-mail address: vssilveira@usp.br.

Key words: Gene expression profile, chemotherapy agents, ALL, treatment outcome.

\section{Conflicts of Interest}

All the authors declared that have no potential conflicts of interest.

\section{Summary}


Acute lymphoblastic leukemia (ALL) is the most common cancer in childhood and approximately $80 \%$ can be now cured. However, the $20 \%$ remaining patients eventually leads to treatment failure. The present study was conducted to validate the microarray data previously reported by Holleman, et al. (2004) and evaluate the expression profile of genes associated to resistance or sensibility to chemotherapy agents in 140 consecutive childhood ALL patients. We analyzed the expression profile of 19 genes related to vincristine (RPLP2, CD44, TCFL5, KCNN1, TRIM24), prednisolone (F8A, CDK2AP1, BLVRB, CD69), daunorubicin (MAP3K12, SHOC2, PDCH9, EGR1, KCNN4) and L-asparaginase (GPR56, MAN1A1, CLEC11A, IGFBP7, GATA3) by real-time quantitative PCR. The results showed many significant associations $(p<0.05)$ between the high expression levels of the genes and important prognostic factors as WBC count at diagnosis (GPR56, BLVRB, SHOC2, IGFBP7), CALLA positive (SHOC2, GATA3, MAN1A1, CD44, MAP3K12, KCNN1), immunophenotype $B$ ( $P C D H 9$, GATA3, KCNN1) and MRD positive at day 28 (CD69, PCDH9, KCNN1, TCFL5, TRIM24). The genes TCFL5 and TRIM24 were also associated with TEL/AML1 negative. The over expression of the gene SHOC2 was also associated to better $4 \mathrm{y}$-EFS in univariate and multivariate analysis ( $p=0.023$ and $p=0.05$ respectively). These findings indicate that some of the analyzed genes could act as prognostic markers, specially the gene SHOC2 which was notably associated with good prognostic factors, suggesting that this gene could play an important role in the ALL treatment outcome.

\section{Introduction}

Childhood acute lymphoblastic leukemia (ALL) is the most common malignant disorder in children. Major improvements have been made in the ALL treatment, which achieved successful rates of approximately $80 \%$ of long-terms survival over the past four decades [1]. Despite the significant percentage of success, the remaining $20 \%$ still presents treatment failure, including those who were initially considered as low-risk patients. Furthermore, the surviving patients often present significant levels of toxicity, which warrants the need of new treatment strategies at the diagnosis [2, 3].

The response to therapy in childhood ALL is related to cellular resistance, pharmacokinetics resistance and minimal residual disease. ALL patients' worse prognosis is closely related to the cellular resistance to chemotherapy agents. Prior studies have described several genetic mechanisms, involving DNA-repair genes, drug metabolism genes and resistance and apoptosis regulating proteins, which might be involved in the drug resistance process [4, 5, and 6]. However, the genetic basis of this mechanism already needs to be clarified. Recent studies have demonstrated that gene expression profiles (GEP) can provide classification and risk stratification in leukemia and also identify treatmentspecific alterations in ALL cells [7, 8]. Holleman and colleagues (2004) described on a microarray analysis the identification of gene expression markers predictive of long term outcome in ALL patients. The genes were related to resistance or sensitibility to the chemotherapy agents: prednisolone, vincristine, asparaginase and daunorubicin. The present study was undertaken to analyze and 
validate the gene expression pattern of the previously described [9] genes RPLP2, CD44, TCF5, KCNN1, TRIM34, F8A, CDK2AP1, BLVRB, CD69, MAP3K12, SHOC2, PCDH9, EGR1, KCNN4, GPR56, MAN1A1, CLEC11A, IGFBP7 and GATA3 and determine whether the expression of such genes influences the treatment outcome in Brazilian childhood ALL patients.

\section{Patients and Methods}

Patients

Bone marrow as samples were obtained at diagnosis from 141 consecutive patients with childhood ALL aged 1 to 17 years, classified and treated according to the Brazilian Childhood Leukemia Treatment Group (GBTLI ALL-99) [10] protocol at three different treatment centers and presenting frozen RNA samples of good quality for gene expression studies. The study, approved by the National Research Ethics Committee (CONEP, No. 1971/2005), was based on the Helsinki convention criteria and the persons responsible for the children gave written informed consent to participate. The diagnosis was made by standard morphological analysis and by flow cytometry immunophenotyping. Of the 141 ALL patients studied, 122 (86.5\%) had B-derived ALL (pro-B ALL in 12 cases and common-ALL/pre-B ALL in 110), and 18 (12.8\%) had T cell-derived ALL; ranging in age from 13 months to 17 years (median 5.4 years). Ninety-three patients $(65.9 \%)$ presented a white blood cells (WBC) count lower than $50,000 / \mathrm{dL}$. Seventy-four patients $(52.5 \%)$ were classified as high risk according to the GBTLI ALL-99 protocol. Central nervous system (CNS) involvement at diagnosis was observed in 5 patients (3.5\%). The time of follow-up of patients in complete clinical remission ranged from 34 to 74 months, with a median observation of 51 months and a cut-off date in March 2009. Unfavorable events (death due to any cause or relapse) occurred in 31 patients $(22.0 \%)$. According to the GBTLI ALL-99 protocol, patients older than 9 years and/or with a WBC count at diagnosis $>50,000 / \mathrm{mm}^{3}$ were assigned to the group at high risk for relapse and the remaining ones were assigned to the standard risk group, which received a less intense treatment. Patients were characterized as poor responders, regardless of the initial risk group, if they met one or more of the following criteria during the phase of remission induction : WBC $>5,000 / \mathrm{mm}^{3}$ on day 7 as a proxy for peripheral blast count, M3 bone marrow ( $>25 \%$ blasts) on D14, or M2/M3 bone marrow ( $>5$ and $25 \%$ blasts, respectively) on D28. WBC count instead of blast count was included in GBTLI-99 because a previous GBTLI-93 study had demonstrated that it was a significant prognostic factor and could be easily and reliably performed at any treatment center. If children belonged to the standard risk group at the time of diagnosis, they were reassigned to the treatment protocol of the high risk group. CNS involvement was considered when more than 5 cells $/ \mathrm{mm}^{3}$ with blast cells in cerebrospinal fluid or cranial nerve palsy, were present. All patients, regardless of risk group, received an induction regimen of 4 weeks including prednisone, vincristine, doxorubicin, L-asparaginase, and MADIT (intrathecal methotrexate, Ara-C and dexamethasone). Standard risk patients received courses of consolidation (cyclophosphamide, Ara-C, 6-MP), intensification (methotrexate $2 \mathrm{gr} / \mathrm{m}^{2} \times 4,6-\mathrm{MP}, \mathrm{MADIT}$ ), late consolidation (dexamethasone, vincristine, doxorubicin, L-asparaginase, cyclophosphamide, 6-TG, 
MADIT) and maintenance (6-MP, methotrexate, vincristine, dexamethasone, MADIT). Patients classified as being at high risk of relapse received courses of: block $A$ (methotrexate $2 \mathrm{gr} / \mathrm{m}^{2}, 6-\mathrm{TG}$, AraC $2 \mathrm{gr} / \mathrm{m}^{2} \times 2$, cyclophosphamide, MADIT), block B (methotrexate $2 \mathrm{gr} / \mathrm{m}^{2}, 6-\mathrm{MP}, \operatorname{AraC} 1 \mathrm{gr} / \mathrm{m}^{2} \times 4$, MADIT), intensification (dexamethasone, vincristine, daunomycin, cyclophosphamide, AraC, 6-TG, MADIT), block C (methotrexate $2 \mathrm{gr} / \mathrm{m}^{2}, 6-\mathrm{MP}, \mathrm{AraC} 2 \mathrm{gr} / \mathrm{m}^{2} \times 2$, VP-16, MADIT), block D (ifosfamide, VP-16, MADIT), late consolidation (dexamethasone, vincristine, daunomycin, L-asparaginase, cyclophosphamide, AraC, 6-TG, MADIT), and maintenance (6-MP, methotrexate, vincristine, dexamethasone, MADIT).

\section{Quantitative RT-PCR analysis}

Total RNA was isolated from the bone marrow samples using the TRizol $\Omega$ Reagent (Invitrogen, Carlsbad, CA) according to the manufacture's protocol. The cDNA was generated from 0.2 $\mu \mathrm{g}$ of Purified, DNase-treated total RNA using the Superscript III Platinum Two-Step Quantitative RTPCR Kit (Invitrogen, Carlsbad, CA, USA). The primers for the 19 genes analyzed and for the housekeeping gene were designed using were designed using the Oligo 3.0 software (Whitehead Institute/ MIT Center for Genome Research) and are shown in Table I. The relative mRNA expression levels were quantified using real-time PCR analysis with the ABI PRISM® 7700 Sequence Detection System (Applied Biosystems Inc., Foster City, CA). Amplification of the specific sequences was performed with SYBR尺 Green PCR Master Mix (Applied Biosystems Inc., Foster City, CA). All samples were analyzed in triplicate, using GUSB as the reference gene. Each run was completed with a melting curve analysis to confirm the specificity of amplification and lack of primer dimmers. The efficiency $(E)$ of each primer set was tested on various dilutions of total bone marrow cDNA samples from patients without hematological diseases and was calculated as follows: $E=10(-1 / \mathrm{slope})$ (values ranged from 1.9 to 2.1). To calculate the relative expression of ALL samples was applied the $2^{-\triangle \triangle C T}$ equation [11]. The Ct'means of normal bone marrow samples was used as calibrator.

\section{Western Blotting Analysis}

To prepare total protein extraction, TRizol® Reagent (Invitrogen, Carlsbad, CA) was used according to the manufacture's protocol. Fifty $\mu \mathrm{g}$ proteins were size-fractioned by $12.0 \%$ SDS gel electrophoresis, blotted onto nitrocellulose membrane and incubated in $1 \%$ Tris-buffered saline Tween-20 (TBST) containing 5\% (w/v) dried non-fat milk for 1 hour at room temperature. After blocking, and washing in PBS with $0.1 \%$ Tween 20 for 30 min, each membrane was then incubated with goat anti-rabbit SHOC2 polyclonal Ab (AbCam, Cambridge, MA) for $1 \mathrm{~h}$. Following membrane incubation, the membrane was washed three times in PBS with $0.1 \%$ Tween 20 , and bound to labeled horseradish peroxidase conjugated secondary Ab goat anti-rabbit IgG (AbCam, Cambridge, USA). Secondary antibody was visualised by an enhanced chemiluminescence's reagent (ECL; Amersham, Uppsala, Sweden) and films were exposed from 30 to 60 seconds and then developed (Figure 1). 


\section{Statistical Analysis}

The association between the variables analyzed and gene expression levels of each marker was determined by the Mann-Whitney test. The association between expression values lower or higher than the median values and the variables analyzed was also determined by logistic regression, with calculation of the odds ratio $(\mathrm{OR})$ and $95 \%$ confidence interval $(95 \% \mathrm{Cl})$. Statistical analysis was carried out using Kaplan-Meier curves for event-free survival (EFS), with relapse and/or death due to any cause considered as unfavorable events. Curves for different groups were compared by the logrank test. The Cox proportional regression model was used for multivariable analysis of prognostic factors. To evaluate the gene expression association among the genes analyzed, the Spearman correlation test was used. The level of significance was set at $P \leq 0.05$ in all analyses. Data were analyzed statistically using the SPSS Graduate Pack 15.0 software (SPSS Inc, Chicago, IL, USA).

\section{Results}

The expression profile of the genes related to resistance or sensibility to chemotherapy agents was analyzed regarding the clinical features of the ALL patients. The data presented in Table 2 summarize the qRT-PCR results of the 19 genes analyzed in bone marrow using GUS $\beta$ as the reference gene compared to age, WBC count at diagnosis, risk group (standard or high risk), response rate to induction treatment response (good or poor responders). In addition, the immunophenotype (Blineage ALL versus T-ALL), CNS involvement and status (complete continuous remission versus unfavorable event) were determined. The analysis of WBC count at diagnosis showed a statistic correlation $(p<0.05)$ with the expression profile of the genes BLVRB, GPR56, IGFBP7 and SHOC2. The presence of CALLA was associated to the genes GATA3, KCNN1, MAN1A1 and SHOC2 and the absence with the genes $C D 44$ and MAP3K12 $(p<0.05)$. We also observed a significant association $(p<0.05)$ between the levels of expression of the genes CD69, PCDHP, KCNN1, TCFL5 and TRIM24 and the presence of MRD at day $28(p<0.037)$. Regarding the chromosome Ph1, the expression profile of the genes TCFL5, KCNN1 and TRIM24, showed a significant association $(p=0.05)$ between the genes over expression and the absence of TEL/AML1 translocation. Among the results was also observed a positive correlation between higher rates of MAP3K12 gene expression and the T-derived $\operatorname{ALL}(p=0.006)$. The others clinical variants analyzed did not show any significant difference (Table 2$)$.

In order to analyze a possible correlation between the expressions of all the genes analyzed, ratios and long term EFS, the patients with ALL were divided in two groups using the median value of the expression of the respective genes and ratios as a cut-off between low and high expression. Fiveyear EFS was $74.7 \pm 5.4 \%$ for the patients as a whole, being $84.2 \pm 4.2 \%$ for patients classified as standard risk and $70.6 \pm 5.2 \%$ for patients classified as high risk. When analyzing the SHOC2 gene, regarding the patient's overall survival, those patients who presented expression values above the median presented a higher 5-year EFS $(85.9 \pm 2.7 \%$ versus $69.6 \pm 3.4 \%, P=0.023)$ (Figure 2). Besides, a significant correlation between the expression levels of SHOC2 and PCDH9 and EGR1genes was observed by the Spearman test (correlation coefficient $0.176, P=0.038 ; 0.207$, 
$p=0.014$ respectively).No other associations between those genes expression profile and clinical and biological variables analyzed were observed.

\section{Protein Analysis}

In order to validate the data obtained from qRT-PCR, western blot analysis was performed for SHOC2 protein as it was the only gene which higher levels of expression were associated with better EFS. The results obtained for SHOC2 western blot analysis confirmed the data obtained in quantitative mRNA analysis. Where over and down mRNA expression of ALL samples were confirmed in protein analysis. (Figure $1 \mathrm{~A}$ ) 
Table 1. Sequence of primers used in quantitative real-time RT-PCR analy marrow samples

\begin{tabular}{|c|c|c|c|}
\hline Gene Symbol & NCBI Accession & Forward primer $\left(5^{\prime} \rightarrow 3^{\prime}\right)$ & Reverse primer $\left(5^{\prime} \rightarrow 3^{\prime}\right)$ \\
\hline \multicolumn{4}{|l|}{ Vincristine } \\
\hline$R P L P 2$ & NM_001004.3 & ACGTACTTGCCCAGGGTAT & GCAGCAGAGACGGCTACAG \\
\hline CD44 & NM_000610.3 & AGAAGGTGTGGGCAGAAGAA & ACTTGGCTTTCTGTCCTCCA \\
\hline TCFL5 & NM_006602.2 & GAGAGGCATAACCGAATGGA & TGCAGAACGGCACTAAGAGA \\
\hline KCNN1 & NM_002248.3 & TTCAGCATCTCCTCCTGGAT & GCTGGTCACTTCCTGCTTGT \\
\hline TRIM24 & NM_003852.3 & CTGAGGTTCCCAGCAGTACA & ACACGTCTTGCAGAGCCATT \\
\hline \multicolumn{4}{|l|}{ Prednisolone } \\
\hline$F 8 A$ & NM_012151.3 & CTTCCCGAGGAGCTCTTTCT & GTGGGTAGCCATGACCAAAG \\
\hline$C D K 2 A P 1$ & NM_004642.2 & GAAGAGCTGGGGAAGGAGAT & GCAGCTAGGATCTGGCATTC \\
\hline$B L V R B$ & NM_000713.2 & CCTGAAGTACGTGGCTGTGA & CCCAGGTCATGTTTGGAGAT \\
\hline CD69 & NM_001781.2 & AGGAACACTGGGTTGGACTG & CATGCTGCTGACCTCTGTGT \\
\hline \multicolumn{4}{|l|}{ Daunorubicin } \\
\hline MAP3K12 & NM_006301.2 & GGTGTGGGAAGCAACAGTCT & GCGATTTCGTGGTTTGCTAT \\
\hline SHOC2 & NM_007373.3 & TGCTTAGCATTCGAGAGAACAA & TGTGAGCTACATCCAGCGTAA \\
\hline PCDH9 & NM_020403.4 & CCAAGGAGGCTTCAAGACAA & GAGCCATCAGGGAGATGAAA \\
\hline EGR1 & NM_000238.2 & TGACCGCAGAGTCTTTTCCT & GCGATTTCGTGGTTTGCTAT \\
\hline KCNN4 & NM_002250.2 & CGGGAACAAGTGAACTCCAT & CCAGCGTGTCAATCTGTTTC \\
\hline \multicolumn{4}{|l|}{ L-Asparaginase } \\
\hline GPR56 & NM_001145770.1 & TCAGCCAGTTCCTGAAGCAT & СTCCTCGAAGGACACCATGT \\
\hline MAN1A1 & NM_005907.2 & GGCCCAACACTACCTTGAAC & TGTAGCGATGGCTTCAACAC \\
\hline CLEC11A & NM_002975.2 & TTGGAGGGCTGCCTGAAG & CGAGAGCAGGAAGCACTTGT \\
\hline IGFBP7 & NM_001553.1 & GGGTCACTATGGAGTTCAAAGG & GCATGGCACTCATATTCTCCA \\
\hline GATA3 & NM_001002295.1 & CCGCCCTACTACGGAAACTC & CAGGGTAGGGATCCATGAAG \\
\hline \multicolumn{4}{|l|}{ House keeping } \\
\hline GUSB & NM_000181.2 & GAAAATATGTGGTTGGAGAGCTCATT & CCGAGTGAAGATCCCCTTTTTA \\
\hline
\end{tabular}




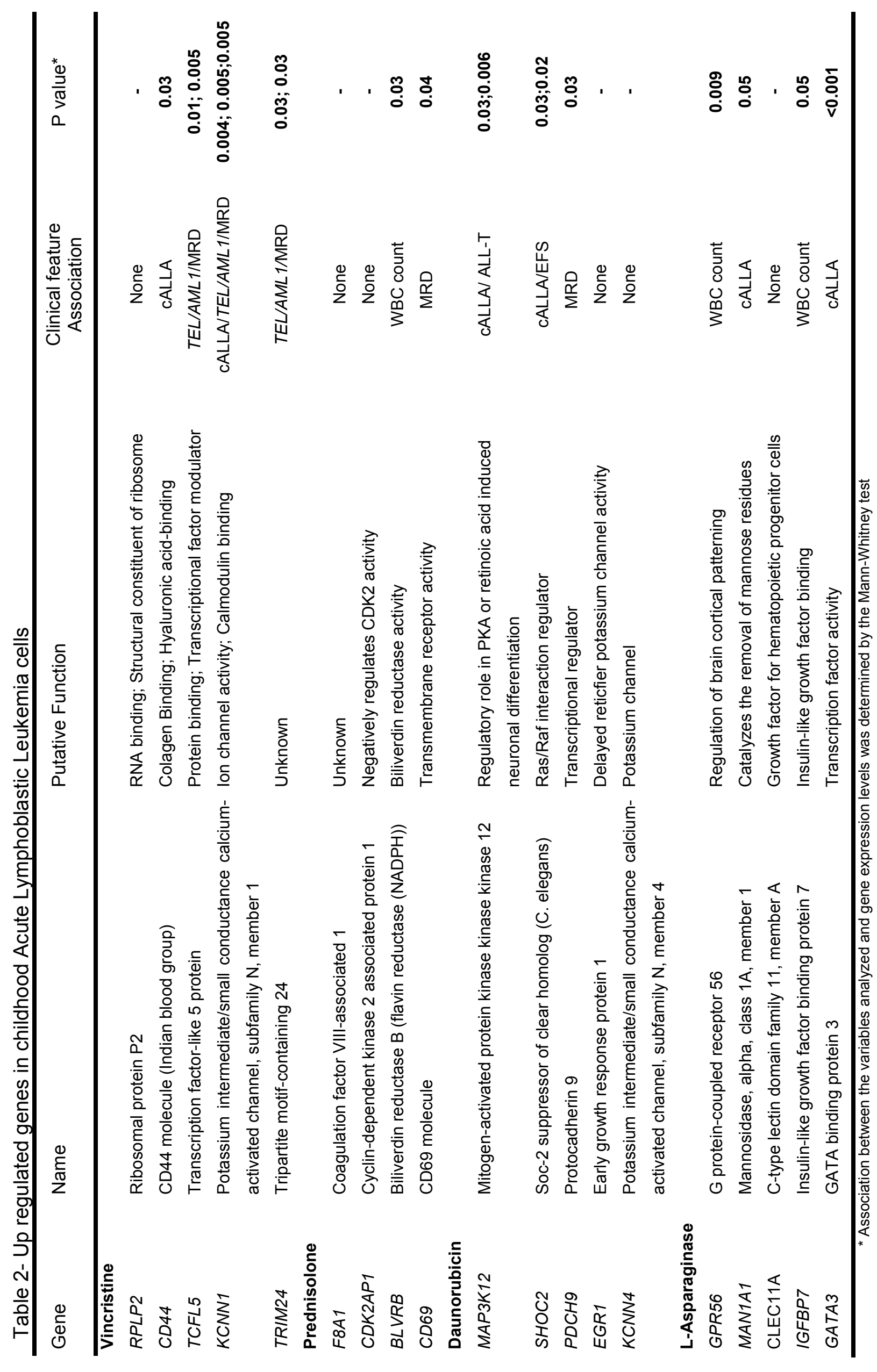




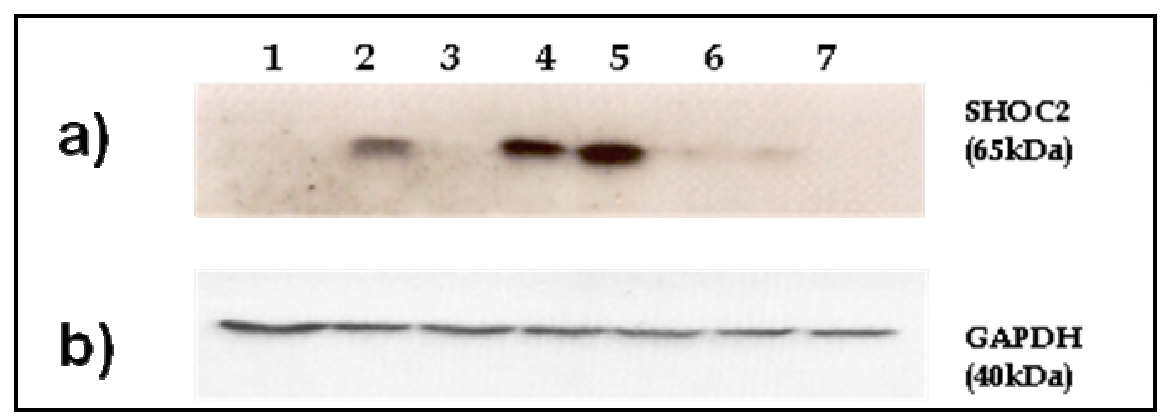

Figure 1: Protein Analysis. (a) SHOC2. ALL samples. Lanes 2, 4 and 5: Over expression pattern; Lanes 1, 3, 6 and 7: Down expression pattern. (b) GAPDH was used as endogenous control.

\section{Discussion}

Here, we evaluated and compared mRNA levels of 19 genes in childhood acute lymphoblastic leukemia. As mentioned before, these genes were previously described by Holleman et al, (2004) and are associated with four chemotherapy drugs: prednisolone, asparaginase, vincristine and daunorubicin. The ALL treatment's response is determined by the entire process of leukemic-cell biological features and the intrinsic drug sensitivity [1;12].Several studies used in vitro drug sensitivity assays to identify genes probably related do drug resistance and many of these studies focused in specifically subsets of ALL as BCR/ABL positive and ALL T - derived. Despite the interesting results obtained until the present day, the function of the most recently identified genes does not necessarily links to drug resistance, thus indicating that the continuous identification of genes that are commonly associated with treatment response in different studies could help focusing on the most relevant cellular functions and molecular pathways in ALL [13-15].

In the present study, many positive associations with gene expression profile and clinical features like WBC count at diagnosis, CALLA positive and MRD at day 28 were found. The gene expression of the genes CD69, PCDH9, KCNN1, TCFL5 and TRIM24 were highly associated to the presence of MRD at day 28 suggesting that genes could be interesting as poor prognostic markers. However, this is the first data to describe this association, so that, more investigation studies could be necessary to clarify the real correlation of these genes and the presence of MRD.

On the other hand, the up regulation of SHOC2 gene showed a significant association with better rates of EFS, suggesting an important involvement of this gene on the treatment outcome process. The SOC2 gene, also known as SUR8 was primarily described in C. elegans and encodes a leucine-rich repeats (LRR) protein that is involved in protein-protein interactions [16]. Its human homolog, SHOC2, shows high levels of sequences identity, indicating that they can possibly chare cellular functions. Derek and colleagues, (1998) described the putative function of Shoc2 as an important RAS regulator which acts downstream, probably interacting with RAF1. Although is widely known that Ras can directly binds to Raf upon activation, the presence of Shoc2 can increases this interaction and activate the downstream molecules as Erk, which is the final pathway effector and responsible of activating regulators for normal cell differentiation, proliferation and also phosporilation of apoptotic regulatory molecules $[17,18]$. In addition, other important aspect reported by Rodriguez- 
Viciana and cols (2006), is the fact that Shoc2 does not bind to the Ras mutant forms, which support the hypothesis that Shoc2 could participate of normal processes of cell proliferation and differentiation which is regulated by Ras e Raf [19-21]. Furthermore, the importance of Shoc2 on Ras activation pathway was clearly described [19] thru its fundamental rule in the ternary complex formation together with the catalytic enzyme phosfatase 1 (PP1c), which it essential for Erk activation. However, the exact molecular mechanism of Raf activation still needs to be clarified. Despite the lack of data association of Shoc2's activity in leukemogenesis processes, as well as patients' treatment outcome and survival rates, the present data is the first to report to describes the possible correlation between Shoc2 and the great outcome of ALL patients, suggesting that this protein could play an important role as a therapy marker.

Notwithstanding the advances made in the ALL treatment, the remaing patients who experienced the relapse following remission induction still represent death in about $20 \%$ of the patients $[22,23]$, showing the remarkably identification importance of discriminating genes possibly involved in ALL treatment outcome, specially those which could better explain the molecular mechanisms of drug resistance [24-27]. In this study, we demosntrate several genes which could be associated to poor prognostic features and apart from that, our findings identified the gene SHOC2 as an important factor associated to treatment outcome, suggesting its possible participation as a therapy marker in ALL treatment outcome. Despite the need of futher approaches to better understand the real participation of SHOC2, this data is of great importance as identified a new possible therapy target.

\section{References}

[1]. Pui $\mathrm{CH}$, Evans WE. Treatment of acute lymphoblastic leukemia. N Engl J Med. 2006 Jan 12;354(2):166-78.

[2]. Evans WE, Relling MV. Moving towards individualized medicine with pharmacogenomics. Nature. 2004 May 27;429(6990):464-8.

[3]. Pui, C. H. et al. Extended follow-up of long-term survivors of childhood acute lymphoblastic leukemia. N. Engl. J. Med. 349, 640-649 (2003).

[4]. Flotho C, Coustan-Smith E, Pei D, Cheng C, Song G, Pui CH, Downing JR, Campana D. A set of genes that regulate cell proliferation predicts treatment outcome in childhood acute lymphoblastic leukemia. Blood. 2007 Aug 15;110(4):1271-7. Epub 2007 Apr 24.

[5]. Krajinovic M, Labuda D, Sinnett D. Glutathione S-transferase P1 genetic polymorphisms and susceptibility to childhood acute lymphoblastic leukaemia. Pharmacogenetics 2002; 12: 655-58.

[6]. da Silva Silveira V, Canalle R, Scrideli CA, Queiroz RG, Bettiol H, Valera ET, Tone LG. Polymorphisms of xenobiotic metabolizing enzymes and DNA repair genes and outcome in childhood acute lymphoblastic leukemia. Leuk Res. 2009 Jul;33(7):898-901. Epub 2009 Jan 21.

[7]. Flohr T, Schrauder A, Cazzaniga G, et al. Minimal residual disease-directed risk stratification using real-time quantitative PCR analysis of immunoglobulin and T-cell receptor gene rearrangements in the international multicenter trial AIEOP-BFM ALL 2000 for childhood acute lymphoblastic leukemia. Leukemia. 2008;22:771-782. 
[8]. Yeoh EJ, Ross ME, Shurtleff SA, et al. Classification, subtype discovery, and prediction of outcome in pediatric acute lymphoblastic leukemia by gene expression profiling. Cancer Cell. 2002; $1: 133-143$

[9]. Holleman A, Cheok MH, den Boer ML, et al. Gene-expression patterns in drug-resistant acute lymphoblastic leukemia cells and response to treatment. N Engl J Med. 2004;351:533-542

[10]. Brandalise, S.R. Odone, V., Pereira W.V. et al. (1993). Teatment results of three Consecutive Brazilian Cooperative Childhood ALL Protocols : GBTLI $80-82$ and 85. Leukemia, 7(2) : $142-145$.

[11]. Livak KJ, Schmittgen TD.Methods. Analysis of relative gene expression data using real-time quantitative PCR and the 2(-Delta Delta C(T)) Method. 2001 Dec;25(4):402-8.

[12]. Pui $\mathrm{CH}$, Campana D, Evans WE. Childhood acute lymphoblastic leukaemia: current status and future perspectives. Lancet Oncol 2001; 2: 597-607.

[13]. Lugthart S, Cheok MH, den Boer ML, et al. Identification of genes associated with chemotherapy crossresistance and treatment response in childhood acute lymphoblastic leukemia. Cancer Cell. 2005;7:375-386.

[14]. Holleman A, den Boer ML, de Menezes RX, et al. The expression of 70 apoptosis genes in relation to lineage, genetic subtype, cellular drug resistance, and outcome in childhood acute lymphoblastic leukemia. Blood. 2006;107:769-776.

[15]. Sorich MJ, Pottier N, Pei D, et al. In vivo response to methotrexate forecasts outcome of acute lymphoblastic leukemia and has a distinct gene expression profile. PLoS Med. 2008;5:e83.

[16]. Selfors LM, Schutzman JL, Borland CZ, Stern MJ. Soc-2 encodes a leucine-rich repeat protein implicated in fibroblast growth factor receptor signaling. Proc Natl Acad Sci U S A. 1998 Jun 9;95(12):6903-8.

[17]. Derek S. Sieburth, Qun Sun, and Min Han* SUR-8, a Conserved Ras-Binding Protein with Leucine-Rich Repeats, Positively Regulates Ras-Mediated Signaling in C. elegans Cell. 1998;Vol. 94, $119-130$.

[18]. Li, W., Han, M., and Guan, K.L. (2000). The leucine-rich repeat protein SUR-8 enhances MAP kinase activation and forms a complex with Ras and Raf. Genes Dev. 14, 895-900.

[19]. Rodriguez-Viciana P, Oses-Prieto J, Burlingame A, Fried M, McCormick F. A phosphatase holoenzyme comprised of Shoc2/Sur8 and the catalytic subunit of PP1 functions as an M-Ras effector to modulate Raf activity. Mol Cell. 2006 Apr 21;22(2):217-30.

[20]. Robinson MJ, Cobb MH. Mitogen-activated protein kinase pathways. Curr Opin Cell Biol. 1997 Apr;9(2):180-6.

[21]. Huang YZ, Zang M, Xiong WC, Luo Z, Mei L. Erbin suppresses the MAP kinase pathway. J Biol Chem. 2003 Jan 10;278(2):1108-14.

[22]. Pui CH, Relling MV, Downing JR. Acute lymphoblastic leukemia. N Engl J Med 2004; 350:153548.

[23]. Cazzaniga G, Biondi A. Molecular monitoring of childhood acute lymphoblastic leukemia using antigen receptor gene rearrangements and quantitative polymerase chain reaction technology. Haematologica. 2005 Mar;90(3):382-90.

[24]. Kastan, M. B. \& Bartek, J. Cell-cycle checkpoints and cancer. Nature 432, 316-323 (2004). 
[25]. Karagiannis, T. C. \& El-Osta, A. RNA interference and potential therapeutic applications of short interfering

RNAs. Cancer Gene Ther. 12, 787-795 (2005).

[26]. Thomas, M., Gessner, A., Vornlocher, H. P., Hadwiger, P., Greil, J. \& Heidenreich, O. Targeting MLL-AF4 with short interfering RNAs inhibits clonogenicity and engraftment of $t(4 ; 11)$-positive human leukemic cells.

Blood 106, 3559-3566 (2005).

[27]. Wei G, Twomey D, Lamb J, et al. Gene expression-based chemical genomics identifies rapamycin as a modulator of MCL1 and glucocorticoid resistance. Cancer Cell. 2006;10:331-342. 